Pace University

DigitalCommons@Pace

$12-2000$

\title{
The Second Amendment: Structure, History, and Constitutional Change
}

David S. Yassky

Elisabeth Haub School of Law at Pace University

Follow this and additional works at: https://digitalcommons.pace.edu/lawfaculty

Part of the Constitutional Law Commons, and the Second Amendment Commons

\section{Recommended Citation}

David Yassky, The Second Amendment: Structure, History, and Constitutional Change, 99 Mich. L. Rev. 588 (2000), http://digitalcommons.pace.edu/lawfaculty/928/.

This Article is brought to you for free and open access by the School of Law at DigitalCommons@Pace. It has been accepted for inclusion in Pace Law Faculty Publications by an authorized administrator of DigitalCommons@Pace. For more information, please contact dheller2@law.pace.edu. 


\title{
THE SECOND AMENDMENT: STRUCTURE, HISTORY, AND CONSTITUTIONAL CHANGE
}

\author{
David Yassky*
}

\section{TABLE OF CONTENTS}

I. THE Founders' VISION OF THE SECOND AMENDMENT

A. The Roles of the Army and the Militia in the Founders'

Political Theory.

B. The Military Clauses of the Original Constitution

1. The Dangers of a National Army............................................602

2. The Need for a National Army...................................................603

3. The Founders' Solution: State Militia as Both Alternative and Counterweight to a National Army ..................................605

C. The Framing of the Second Amendment

D. Second Amendment Practice in the Founding Period

II. Evaluating the Revisionist ARgument

A. The "Collective Rights" Red Herring 613

B. The Libertarian Red Herring 615

C. The Revisionists' Best Shot: The "Unorganized Militia Approach".

D. "Translating" the Second Amendment.

III. Dismantling THE Founders' FramewORK

A. The Civil War Watershed 631

B. The Original Understanding of Conscription 634

1. Text

2. Legislative History

3. Contemporary Practice

4. Constitutional Structure

C. The Fourteenth Amendment's Legitimation of the Draft. .638

1. Text: Military Service as a Duty of "Citizens of the United States"

2. Legislative History: The Relationship Between the Conscription Act and the Fourteenth Amendment.

* Assistant Professor of Law, Brooklyn Law School. I am grateful to Bruce Ackerman, Michael Bellesiles, Saul Cornell, Susan Herman, Michael Madow, Robert Schapiro, Paul Schwartz, Spencer Waller, and Steven Winter for their helpful comments on drafts of this Article. I discussed some of the arguments developed here at a Brooklyn Law School Faculty Forum and in a Brooklyn Law School seminar on Federalism, and I thank the participants for their suggestions. I also thank Donia Farhoud, Beverly Farrell, Michael Flake, Amy Kleitman, and Thomas Lookstein for their first-rate research assistance, Gwen Applewhite for her excellent secretarial assistance and the Brooklyn Law School Summer Research Stipend Program, which funded my work on this Article. 
3. Structure: The Demise of the Founders' Federalism ..............644

IV. TOWARD A THEORY OF THE MODERN SECOND AMENDMENT.....648

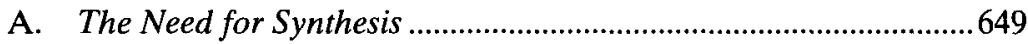

B. Why the Revisionists' Theory of Second Amendment

"Incorporation" is Incomplete.

1. The Incorporation Conundrum .............................................652

2. The Road to Incorporation ...................................................654

C. Synthesizing the New Deal: The First and Second

Amendments Compared.

D. United States v. Miller and the Failure of the Courts.

.665

A well regulated Militia, being necessary to the security of a free State, the right of the people to keep and bear Arms, shall not be infringed. -United States Constitution, Amendment II

A fierce debate about the Second Amendment has been percolating in academia for two decades, and has now bubbled through to the courts. The question at the heart of this debate is whether the Amendment restricts the government's ability to regulate the private possession of firearms. Since at least 1939 - when the Supreme Court decided United States $v$. Miller, ${ }^{1}$ its only decision squarely addressing the scope of the right to "keep and bear Arms" - the answer to that question has been an unqualified "no." Courts have brushed aside Second Amendment challenges to gun control legislation, reading the Amendment to forbid only laws that interfere with states' militias. ${ }^{2}$

\section{307 U.S. 174 (1939).}

2. Courts have upheld federal laws regulating the private possession of short-barreled shotguns, see Miller, 307 U.S. at 174, machine guns, see, e.g., United States v. Rybar, 103 F.3d 273 (3d Cir. 1996), cert. denied, 522 U.S. 807 (1997); United States v. Hale, 978 F.2d 1016 (8th Cir. 1992); United States v. Oakes, 564 F.2d 384 (10th Cir. 1977); United States v. Warin, 530 F.2d 103 (6th Cir. 1976), cert. denied, 426 U.S. 948 (1976), and assault weapons, see San Diego Gun Rights Comm. v. Reno, 98 F.3d 1121 (9th Cir. 1996). They have also upheld laws prohibiting the possession of firearms by felons, see, e.g., United States $v$. Johnson, 497 F.2d 548 (4th Cir. 1974); United States v. Synnes, 438 F.2d 764 (8th Cir. 1971); Cases v. United States, 131 F.2d 916 (1st Cir. 1942), by persons convicted of domestic violence offenses, see, e.g., Fraternal Order of Police v. United States, 173 F.3d 898 (D.C. Cir. 1999), and by persons subject to restraining orders, see, e.g., United States v. Baker, 197 F.3d 211 (6th Cir. 1999); Gillespie v. City of Indianapolis, 185 F.3d 693 (7th Cir. 1999); United States v. Spruill, 61 F. Supp. 2d 587 (W.D. Tex. 1999). But see United States v. Emerson, 46 F. Supp. 2d 598 (N.D. Tex. 1999) (striking down federal statute prohibiting the possession of firearms persons subject to restraining orders). Courts have also upheld extensive federal regulation of firearms dealers, see United States v. Decker, 446 F.2d 164 (8th Cir. 1971); $c f$. Cody v. United States, 460 F.2d 34 (8th Cir. 1972) (upholding requirement that gun purchasers accurately answer certain questions prior to purchase).

Moreover, the Supreme Court has never held that the Second Amendment is "incorporated" in the Fourteenth Amendment's protections. Accordingly, courts have uniformly rejected Second Amendment challenges to state or local firearms regulations, see, e.g., Peoples Rights Org. v. City of Columbus, 152 F.3d 522 (6th Cir. 1998); Love v. Pepersack, 47 F.3d 120 (4th Cir. 1995), cert. denied, 516 U.S. 813 (1995); Thomas v. City Council of Portland, 730 F.2d 41 (1st Cir. 1984); Quilici v. Village of Morton Grove, 695 F.2d 261 (7th Cir. 1982), cert. denied, 464 U.S. 863 (1983). The Supreme Court last addressed the question in 1886, 
Recently, however, that judicial orthodoxy has come under attack from a group of revisionist scholars. ${ }^{3}$ Rather than protecting only the states' militia, the revisionists have argued, the Amendment "protects an individual right inherent in the concept of ordered liberty."

holding that the Amendment does not apply to states - but of course this holding predates modern incorporation jurisprudence. See Presser v. Illinois, 116 U.S. 252 (1886); $c f$. infra Section IV.A.1.

3. This literature has now become quite large. For representative examples, see Stephen P. Halbrook, That Every Man Be ARMEd: THE Evolution OF a CONSTITUTIONAL RIGHT (1984); JOYCE LEE MALCOLM, TO KEEP AND BEAR ARMS: THE ORIGINS OF AN ANGLO-AMERICAN RIGHT (1994); Randy Barnett \& Don B. Kates, Under Fire: The New Consensus on the Second Amendment, 45 EMORY L.J. 1139, 1141 (1996); Robert Dowlut, Federal and State Constitutional Guarantees to Arms, 15 U. DAYTON L. REV. 59 (1989); Don B. Kates, Jr., Handgun Prohibition and the Original Meaning of the Second Amendment, 82 MICH. L. REV. 204 (1983) [hereinafter Kates, Jr., Original Meaning]; Don B. Kates, Jr., The Second Amendment: A Dialogue, 49 LAW \& CoNTEMP. ProbS. 143 (1986); Sanford Levinson, The Embarrassing Second Amendment, 99 YALE L.J. 637 (1989); Nelson Lund, The Past and Future of the Individual's Right to Arms, 31 GA. L. REV. 1 (1996); L.A. Powe, Jr., Guns, Words and Constitutional Interpretation, 38 WM. \& MARY L. Rev. 1311 (1997); Glenn Harlan Reynolds, A Critical Guide to the Second Amendment, 62 TENN. L. REV. 461 (1995); William Van Alstyne, The Second Amendment and the Personal Right to Arms, 43 DuKE L.J. 1236 (1994); Eugene Volokh, The Commonplace Second Amendment, 73 N.Y.U. L. REV. 793 (1998). For a complete bibliography, see David B. Kopel, The Supreme Court's Thirty-Five Other Gun Cases: What the Supreme Court Has Said About the Second Amendment, 18 ST. LOUIS U. PUB. L. REV. 99, 101 n.9 (1999).

There is also a substantial body of work by both legal scholars and historians disputing the revisionists. The legal scholarship includes: Carl T. Bogus, Race, Riots, and Guns, $66 \mathrm{~S}$. CAL. L. REV. 1365 (1993) [hereinafter Bogus, Race, Riots and Guns]; Carl T. Bogus, The Hidden History of the Second Amendment, 31 U.C. DAVIS L. REV. 309 (1998) [hereinafter Bogus, Hidden History]; Keith A. Ehrman \& Dennis A. Henigan, The Second Amendment in the Twentieth Century: Have You Seen Your Militia Lately?, 15 U. DAYTON L. REV. 5 (1989); Dennis A. Henigan, Arms, Anarchy and the Second Amendment, 26 VAL. U. L. REV. 107 (1991); Andrew D. Herz, Gun Crazy: Constitutional False Consciousness and Dereliction of Dialogic Responsibility, 75 B.U. L. REV. 57 (1995); John Dwight Ingram \& Allison Ann Ray, The Right(?) to Keep and Bear Arms, 27 N.M.L. REV. 491 (1997); H. Richard Uviller \& William G. Merkel, The Second Amendment in Context: The Case of the Vanishing Predicate, 76 CHI-KenT L. REV. 403 (2000); David C. Williams, Civic Republicanism and the Citizen Militia: The Terrifying Second Amendment, 101 YALE L.J. 551 (1991) [hereinafter Williams, The Terrifying Second Amendment]; David C. Williams, The Militia Movement and Second Amendment Revolution: Conjuring with the People, 81 CORNELL L. REV. 879 (1996) [hereinafter Williams, Conjuring with the People]; David C. Williams, The Unitary Second Amendment, 73 N.Y.U. L. Rev. 822 (1998). The historians' work includes: Michael Bellesiles, The Origins of Gun Culture in the United States 1760-1865, 83 J. AM. HIST. 425 (Sept. 1996) [hereinafter Bellesiles, Gun Culture]; Michael Bellesiles, Gun Laws in Early America: The Regulation Of Firearms Ownership 1607-1794, 16 LAW \& HIST. REV. 567 (1998) [hereinafter Bellesiles, Gun Laws]; Michael Bellesiles, Suicide Pact: New Readings of the Second Amendment, 16 CONST. COMMENTARY 247 (1999) [hereinafter Bellesiles, Suicide Pact]; Saul Cornell, Commonplace or Anachronism: The Standard Model, the Second Amendment, and the Problem of History in Contemporary Constitutional Theory, 16 CONST. Commentary 221 (1999); Lawrence D. Cress, An Armed Community: The Origins and Meaning of the Right to Bear Arms, 71 J. AM. HIST. 22 (1984); Don Higginbotham, The Second Amendment in Historical Context, 16 CONST. COMMENTARY 263 (1999).

4. Emerson, 46 F. Supp. at 600 (summarizing views of revisionist scholars). I distinguish below between two versions of the revisionist claim: a libertarian version expressed in this quotation, and an alternate, also far-reaching version that pictures the American citizenry as an "unorganized militia." See infra Sections II.B and II.C. 
The revisionist position emerged in the 1980s and has won growing acceptance among constitutional scholars. ${ }^{5}$ The breakthrough moment came in 1989, when Sanford Levinson published his article The Embarrassing Second Amendment in the Yale Law Journal. ${ }^{6}$ Levinson largely accepted the revisionists' historical account of the Second Amendment, and he suggested that the Amendment limits legislators' ability to regulate guns to a much greater extent than judges and scholars had theretofore acknowledged.

Levinson's article brought the revisionist project a new level of attention and legitimacy. ${ }^{7}$ Since its publication, the number of revisionist articles has grown substantially, casebooks have begun to recognize the revisionist position, ${ }^{8}$ and other leading constitutional law scholars have joined Levinson in accepting, at least partially, the revisionist argument. ${ }^{9}$ In particular, Akhil Amar's recent tour-de-force The Bill of Rights includes a thorough and powerful argument in support of the revisionist position. ${ }^{10}$

5. Note, however, that acceptance of the revisionist argument has for the most part been limited to legal scholars. For the most part, historians have rejected the revisionists' claims. See sources cited supra note 3 . The impact of this work, in fact, has led to a partial recantation by leading revisionist historian Robert E. Shalhope. Compare Robert E. Shalhope, The Ideological Origins of the Second Amendment, 69 J. AM. HIST. 599 (1982), with Robert E. Shalhope, To Keep and Bear Arms in the Early Republic, 16 CONST. COMMENTARY 269 (1999).

6. Levinson, supra note 3. I should note that while The Embarrassing Second Amendment has been widely read as endorsing revisionist theories, Levinson was careful to stop short of concluding that the Second Amendment prohibits gun control legislation; he merely suggested that the revisionist arguments deserved a more respectful hearing than he believed they were getting. In a later essay, though, Levinson comes closer to stating outright that he believes current doctrine to be mistaken. Sanford Levinson, Is the Second Amendment Finally Becoming Recognized as Part of the Constitution? Voices from the Courts, 1998 BYU L. REV. 127.

7. Writing in 1989 , Levinson noted that "no one recognized by the legal academy as a 'major' writer on constitutional law has deigned to turn his or her talents to a full consideration of the Amendment," Levinson, supra, note 3, at $639 \mathrm{n} .13$, and that "[o]ne will search the leading casebooks in vain for any mention of the Second Amendment," id. at 639 n.14. Those assertions are now obsolete.

8. See, e.g., Paul Brest, Sanford Levinson, J.M. Balkin \& AKhil Reed Amar, PROCESSES OF CONSTITUTIONAL DECISION MAKING 410-13 (4th ed. 2000); DANiEL A. Farber, William N. Eskridge, JR., \& Phillip P. Frickey, Constitutional Law THEMES FOR THE CONSTITUTION'S THIRD CENTURY 416-18 (2nd ed. 1998); GEOFFREY R. Stone, Louis M. SEIDMan, Cass R. Sunstein \& MaRk V. Tushnet, Constitutional. LAW 287 (1998 Supplement). Many leading casebooks, however, continue to omit any discussion of the Second Amendment. See, e.g., DaAN BRaveman, William C. Banks \& Rodney A. SMOLLA, CONSTITUTIONAL LAW: STRUCTURE AND RIGHTS IN OUR FEDERAL SYSTEM (4th ed. 2000); GERALD GUNTHER \& KATHLEEN M. SUlliVAN, CONSTITUTIONAL LAW (13th ed. 1997); RONALD D. ROTUNDA, MODERN CONSTITUTIONAL LAW (6th ed. 2000).

9. See Akhil Amar, The Bill of Rights: Creation and Reconstruction 46-59, 257-66 (1998); LAURENCE H. Tribe, 1 American CONSTITUTIONAL LAW 894-903 (3d ed. 2000).

10. See AMAR, supra note 9 , at 46-59, 257-66. 
Most important, revisionist work has begun to influence the judiciary. In his concurring opinion in the 1997 case Printz v. United States, Justice Thomas (writing only for himself) proposed a reexamination of the Second Amendment. Thomas suggested that the Amendment creates a "personal right to "keep and bear arms," " and he hinted that this right would preclude aggressive gun control regulations. ${ }^{11}$

Just last year, a District Court in Texas followed up on Thomas' suggestion by striking down a federal statute banning persons subject to certain types of restraining orders from possessing firearms. ${ }^{12}$ The decision, United States $v$. Emerson, was only the second in the nation's history in which a federal court used the Amendment to invalidate a gun control law (the first was the District Court decision in Miller which the Supreme Court subsequently reversed in $1939^{13}$ ). Both Justice Thomas' Printz opinion and the Emerson Court relied heavily on revisionist scholarship.

The Second Amendment debate sparked by the revisionists has attracted considerable attention in the press, ${ }^{14}$ presumably because of its possible impact on public policy. If the revisionists are successful in changing doctrine, courts may well narrow the parameters of permissible gun control initiatives. But paving the way for such initiatives is not my concern here. ${ }^{15}$ The real stakes in the Second Amendment debate are not practical, but theoretical.

In his pathbreaking article, Professor Levinson wrote that the Second Amendment is "profoundly embarrassing" to many students of the Constitution. I agree with that characterization, but I disagree with Levinson about the source of the embarrassment. For Levinson, the

11. See Printz v. United States, 521 U.S. 898, 938 (1997) (Thomas, J., concurring) (emphasis in original). Justice Scalia has expressed similar views in a speech. See Antonin Scalia, Common-Law Courts in a Civil-Law System: The Role of United States Federal Courts in Interpreting the Constitution and Laws, in A MATTER OF INTERPRETATION: FEDERAL COURTS AND THE LAW 3, 43 (Amy Gutmann ed., 1997) ("We may like the ... elimination of the right to bear arms; but let us not pretend that these are not reductions of rights.").

12. Emerson, 46 F. Supp. 2 d at 598. Other federal courts, however, have upheld the statute. See, e.g., Baker, 197 F.3d at 211; Gillespie, 185 F.3d at 693; Spruill, 61 F. Supp. 2d at 587.

13. United States v. Miller, 26 F. Supp. 1002 (W.D. Ark.), rev'd 307 U.S. 174 (1939).

14. See, e.g., William Glaberson, Dueling Scholars Join Fray Over a Constitutional Challenge to Gun Control Laws, N.Y. TIMES, Sept. 21, 2000, at A26; David E. Rovella, Circuit Sights Gun Rights, NAT. L. J., June 5, 2000, at 1; Richard B. Schmitt, The 2nd Amendment: It's a Constant - and Confusing - Refrain, WALL ST. J., May 25, 1999, at A1; Richard Willing, Texas Case Could Shape the Future of Gun Control, USA TODAY, Aug. 27, 1999, at 1 A.

15. In the interest of full disclosure, I note that I do believe stronger regulation of firearms would be sound public policy. I make this unusual (for a law review article) comment only because it is common for participants in the scholarly debate over the Second Amendment to suggest that other participants' views on the Amendment are determined by their views on the wisdom of firearms regulations. As I hope will be clear from my arguments in this Article, however, I believe that one's judgment as to the constitutionality of a given public policy ought to be independent of one's views as to the soundness of that policy. 
Amendment calls into question scholars' commitment to resultindifferent interpretive methodology. He noted that the Amendment had (at the time he was writing) been entirely ignored by mainstream constitutional scholars, and he attributed this neglect to a "perhaps subconscious fear that altogether plausible, perhaps even 'winning,' interpretations of the Second Amendment would present real hurdles to those of us supporting prohibitory regulation." 16

The real source of the embarrassment goes deeper. The Amendment is troublesome because it evokes scholars' latent confusion about the sources and mechanisms of doctrinal change in constitutional law. In particular, the Second Amendment, like no other constitutional provision, puts to the test one's commitment to original intent as a source of constitutional meaning.

Most contemporary scholars, whether they call themselves "originalists" or not, believe that constitutional meaning should be derived, at least in part, from the understandings of those who framed and ratified the constitutional text (or perhaps of the citizens whom those framers and ratifiers represented) ${ }^{17}$ The revisionists' argument, which is straightforwardly originalist, poses an uncomfortable challenge to that belief. Their argument, in sum, is this: The framers of the Second Amendment intended for every American citizen to have the right to own guns, free from interference by the federal government; modern courts have approved federal gun control laws that the Founders would certainly have seen as violating the Amendment; accordingly, modern doctrine is illegitimate.

As I will explain below, the revisionists' account of the Founders' understanding of the Second Amendment is substantially accurate, ${ }^{18}$ and so is their claim that modern doctrine departs from that understanding. Even if one does not accept the full sweep of the revisionists' historical claims, it is impossible to deny that the Founders intended the Second Amendment to constrain federal regulation of firearms to at least some degree. Modern doctrine reduces the Amendment to a virtual nullity.

I suspect that many scholars - certainly after Levinson's article and Amar's book - accept the revisionists' claim of a conflict between original intent and modern doctrine. Yet at the same time, many scholars must also find the Founders' vision hopelessly anachro-

16. Levinson, supra note 3, at 642.

17. See Randy E. Barnett, An Originalism for Nonorginalists, 45 LOY. L. REv. 611,613 (1999) (suggesting that "Originalism is now the prevailing approach to constitutional interpretation").

18. Or at least one version of the revisionists' historical account is accurate. I will distinguish below between two different versions of the revisionist argument - what I call the Libertarian Approach and the Unorganized Militia Approach - and argue that the latter is supported by the historical record, while the former is not. See infra Sections II.B and II.C. 
nistic, and modern doctrine intuitively correct - and not just, as Levinson suggests, because they fear the policy consequences of the revisionists' argument.

After all, so much has changed since 1791. The Founders lived in a time when the threat of interstate warfare, or of the federal government using force to subdue dissident states, was real - so real that it actually happened, although not for seventy years. The possibility of armed resistance to government force was also quite real, as demonstrated by Shays' Rebellion in Massachusetts shortly before the Constitution was written, and by the Whiskey Rebellion in Pennsylvania shortly after - not to mention the great triumph over England. Further, widespread and uncontrolled gun ownership poses threats to public safety today undreamed of in $1791 .^{19}$

The problem comes when it is time to put this changedcircumstances argument into doctrinal form. The Second Amendment has not been repealed; the authoritative text remains today what it was in 1791 . Contemporary constitutional theory simply has no widely accepted methodology for understanding how the meaning of unamended constitutional text can change over time ${ }^{20}$. As Laurence Tribe puts it in the latest edition of his treatise, changed circumstances do not mean "that the Second Amendment may properly be deemed wholly irrelevant today or that it may plausibly be construed to do no more than protect state defense forces against outright abolition by Congress. Although the factual predicates assumed by the framers of the Second Amendment no longer obtain, the same could be said with respect to other constitutional provisions."21 Thus the Second Amendment is an embarrassment for Levinson and Tribe in the same way Brown v. Board of Education was an embarrassment for Herbert

19. According to the most recent FBI statistics, firearms are used in sixty-five percent of murders and thirty-eight percent of robberies in the United States. See FEDERAL BUREAU OF INVESTIGATION, U.S. DEP'T OF JUSTICE, CRIME IN THE UNITED STATES (1999) at 18, 29. There is considerable debate among government officials, scholars and the public as to whether the overall level of gun ownership in the United States has any causal relationship to the incidence or lethality of crime, and if so whether gun control statutes can affect this relationship. Compare, e.g., FRANKLIN E. ZIMRING \& GORDON HAWKINS, CRIME Is NOT THE PROBLEM 122-23 (1997) ("Current evidence suggests that a combination of the ready availability of guns and the willingness to use maximum force in interpersonal conflict is the most important single contribution to the high U.S. death rate from violence.") and Mark Duggan, More Guns, More Crime, National Bureau of Economic Research, Working Paper 7967 (October 2000), available at http://www.nber.org/papers/w7967 (arguing that increases in gun ownership result in increases in homicides), with JOHN R. LOTT, JR., MORE GUNS, LESS CRIME (1998) (arguing that regulatory regimes encouraging private gun ownership reduce the incidence of crime victimization).

20. A recent symposium issue of the Yale Law Journal contains several fascinating and provocative reflections on the difficulty of accounting for change in constitutional doctrine. See Symposium, Moments of Change: Transformation in American Constitutionalism, 108 YALE L.J. 1917 (1999).

21. TRIBE, supra note 9 , at 900 . 
Wechsler, ${ }^{22}$ and Roe $v$. Wade is an embarrassment for many scholars today - the substance of contemporary doctrine seems impossible to square with the intentions of the framers of the relevant constitutional text.

But it is possible to accept both the revisionists' historical claims and the modern militia-focused jurisprudence - without embarrassment. To do so, we have to understand the Second Amendment in its textual and temporal context. The first step is to broaden the inquiry beyond the Amendment itself; instead of the revisionists" "clausebound" 23 approach, we must appreciate how the Amendment is linked to other constitutional provisions dealing with military structure. The Amendment must be read in conjunction with those provisions to create a coherent whole.

Next, we must broaden the inquiry beyond the years 1787 to 1791 . This step follows directly from the first; once we are committed to reading the Second Amendment in harmony with the remainder of the Constitution, we must recognize that changes in that remainder may affect our reading of the Second Amendment, if we are to maintain the harmony. And while the text of the Second Amendment has of course remained the same since its ratification, the Constitution that surrounds it has been dramatically amended - most obviously by the Fourteenth Amendment. In other doctrinal areas, we recognize that the insertion into the Constitution of the Fourteenth Amendment has forced courts to reinterpret elements of the preexisting document. ${ }^{24}$ I will argue below for a similar reinterpretation of the "right to keep and bear Arms."

These two steps, I believe, will yield a fuller and more satisfying account of the Second Amendment than either the revisionists or the judicial opinions they attack, while still vindicating the doctrinal conclusions that have been settled since Miller. Only by recognizing that

22. See Herbert Wechsler, Toward Neutral Principles of Constitutional Law, 73 HARV. L. REV. 1, 31-35 (1959).

23. The phrase is Professor Ely's (although he used it, of course, to characterize a general tendency among constitutional scholars, and not with reference to the Second Amendment debate). JOHN HART ELY, DEMOCRACY AND DISTRUST: A THEORY OF JUDICIAL REVIEW 12 (1980).

24. In Bolling v. Sharpe, 347 U.S. 497 (1954), for example, the Supreme Court held that the Due Process Clause of the Fifth Amendment prohibits racial discrimination by the federal government - in effect, reading the Fourteenth Amendment's Equal Protection Clause into the Fifth Amendment. Another, perhaps less obvious, example is modern incorporation doctrine, which holds not only that the Fourteenth Amendment "incorporates" the Bill of Rights, but also that the incorporated amendments should be applied identically against the states and the federal government. See, e.g., Malloy v. Hogan, 378 U.S. 1 (1964). The result is that doctrinal developments in criminal procedure jurisprudence that are motivated primarily by concerns about state practices wind up constraining the federal government as well. Cf. AMAR, supra note 9, at 257-83 (describing how the content of rights granted under the Bill of Rights has been "refined" by the Supreme Court as a result of the Fourteenth Amendment). 
the Second Amendment draws meaning from the Constitution of which it is a part, and that that Constitution has changed over time, can we understand and justify the changes in Second Amendment jurisprudence that Professors Levinson and Tribe find so troubling. Thus my core purpose in this Article is to demonstrate the power of an interpretive methodology that is not only originalist, ${ }^{25}$ but also holistic and historical. ${ }^{26}$

25. This Article is written from an originalist perspective; it presupposes that constitutional meaning should be drawn largely from the understandings of those who wrote and ratified the Constitution, and of the citizens those writers and ratifiers represented. I hope, however, that it will be useful even to those who reject this perspective, by showing that originalism need not bind us to constitutional meanings established 210 years ago. For twenty-first century constitutional interpreters, the relevant writers, ratifiers and citizens include not only the 1790 s Founders, but certainly also the 1860 s Reconstruction Republicans, and perhaps the 1930s New Dealers as well. See BRUCE ACKERMAN, WE THE PEOPLE: FOUNDATIONS 105-58 (1991) (describing the New Deal as an episode of "higher lawmaking" that changed the Constitution) [hereinafter ACKERMAN, FOUNDATIONS]; Bruce Ackerman, We the People: Transformations 255-382 (1998) (same) [hereinafter ACKERMAN, TRANSFORMATIONS].

26. I do not claim that this method is original to me in any way. Rather, holistic interpretation - defined by Charles Black as "the method of inference from the structures and relationships created by the constitution in all its parts," CHARLES L BLACK, JR., STRUCTURE AND RELATIONSHIP IN CONSTITUTIONAL LAW 7 (reprint ed. 1985) - is well-established among constitutional scholars. Many scholars also precede me in seeking to integrate historical change into Black's model, prominent examples being Bruce Ackerman, see ACKERMAN, FOUNDATIONS, supra note 25; ACKERMAN, TRANSFORMATIONS, supra note 25, and Akhil Amar, see AMAR, supra note 9. Indeed, readers who are familiar with the work of Ackerman and Amar will immediately recognize this Article as an attempt to build on that work.

I do believe, however, that while holism and historicism are in theory standard operating procedures, in practice much constitutional interpretation is clause-bound and ahistorical. The Second Amendment revisionists are particularly salient examples, but the roots of these problematic tendencies reach deeply into mainstream scholarship. Consider, for example, efforts to understand constitutional interpretation as an act of "translation." See Lawrence Lessig, Fidelity as Translation: Fidelity and Constraint, 65 FORDHAM L. REV. 1365 (1997) [hereinafter Lessig, Fidelity as Translation]; Lawrence Lessig, Fidelity in Translation, 71 TEXAS L. REV. 1165 (1993) [hereinafter Lessig, Fidelity in Translation]; Lawrence Lessig, Understanding Changed Readings: Fidelity and Theory, 47 STAN. L. REV. 395 (1995) [hereinafter Lessig, Understanding Changed Readings]; see also Steven G. Calabresi, The Tradition of the Written Constitution: A Comment on Professor Lessig's Theory of Translation, 65 FORDHAM L. REV. 1435 (1997); Bradford R. Clark, Translating Federalism: A Structural Approach, 66 GEO. WASH. L. REV. 1161 (1998); Abner S. Greene, Discounting Accountability, 65 FORDHAM L. REV. 1489 (1997); Sanford Levinson, Translation: Who Needs It?, 65 FORDHAM L. REV. 1457 (1997); Deborah Jones Merritt, The Third Translation of the Commerce Clause: Congressional Power to Regulate Social Problems, 66 GEO. WASH. L. REV. 1206 (1998); Jeffrey Rosen, Translating the Privileges or Immunities Clause, 66 GEO. WASH. L. REV. 1241 (1998). While the metaphor of interpretation-as-translation offers valuable insights, it also encourages an interpretive practice that overemphasizes specific pockets of text and leaps from ratification to the present with insufficient regard for the texture of intervening developments. I consider, and reject, the view that modern Second Amendment doctrine is an acceptable "translation" of the Amendment's original meaning infra at Section II.D. More broadly, my hope is to persuade judges and other scholars not only that my account of the Second Amendment is better than that of the revisionists, but that commitment to a genuinely holistic and historicized practice will yield more satisfying results than competing methods offer. 
Part I of the Article engages the revisionists squarely on the turf they have staked out: the intent of those who framed and ratified the Second Amendment. Here I credit the revisionists with some important insights. Their research reminds us how greatly the world in which the Second Amendment was adopted differed from our own. This perspective helps us understand how the Founders could have placed the right to bear arms on par with the right to free speech - a decision that baffles many modern Americans. ${ }^{27}$ Yet while the revisionists correctly perceive that the right to keep and bear arms was crucial to the Founders, they misunderstand precisely why the right was so important. I will argue that the Founders' overriding concern was to ensure that the new nation's military force would be composed of state militias instead of, or at least in addition to, a federal standing army. To the Founders, a standing army posed a threat of both tyranny and ruinous military adventurism. To counter this threat, the Constitution meticulously allocated military power between the federal army and the state militias. The purpose of the Second Amendment was to protect this allocation.

Part II is analytic. My goal is to clarify the debate by identifying the argument at the core of the revisionists' attack on the courts. First, in light of the history recounted in Part I, I hope to discredit a libertarian version of the revisionist approach, which sees activities like hunting and recreational shooting as interests protected by the Second Amendment. This position, while it may be widespread among lay Second Amendment enthusiasts, cannot be supported by the historical record. An alternate version of the revisionist argument, however, is more plausible. According to this theory, the Amendment protects the rights of individual Americans to arm themselves so they can serve as the "unorganized militia" of the several states. This "Unorganized Militia Approach" is a fair reading of the Founders' intent; were we living in the early Nineteenth Century, it would provide the basis for any judicial implementation of the Second Amendment.

Part II also considers the possibility that modern Second Amendment doctrine can be understood as what Lawrence Lessig calls a "translation" of the Amendment's original meaning. ${ }^{28}$ While this understanding is in some ways appealing, in the end I reject it. Contemporary doctrine goes beyond a "translation" that applies the Founders' principles to new and unforeseen facts; it is a repudiation of the principles themselves.

In Part III, I seek to explain this repudiation as a consequence of the Fourteenth Amendment. The Civil War destroyed the Founders'

27. Although, it may be needless to say, there are millions of Americans to whom this equivalence makes perfect sense.

28. See Lessig, Fidelity in Translation, supra note 26; Lessig, Fidelity as Translation, supra note 26; Lessig, Understanding Changed Readings, supra note 26. 
carefully wrought design; by initiating a federal draft, Lincoln replaced the Founders' decentralized military structure with a national army. I will argue that the Fourteenth Amendment made Lincoln's innovations a permanent part of the constitutional framework. One of that Amendment's many ramifications was to legitimize a federal military draft, and concomitantly undermine the role of the states' militia. With the militia rendered constitutionally obsolete, the purpose of the Second Amendment evaporated.

In Part IV, I consider a new strand of the revisionist argument, which understands the impact of the Fourteenth Amendment to be precisely the opposite of what I am suggesting. This argument, made most persuasively by Akhil Amar, ${ }^{29}$ claims that the Fourteenth Amendment was intended to reaffirm and expand - "incorporate," in modern parlance - the Bill of Rights. As the Second Amendment is part of the Bill, Amar argues, we should understand the Fourteenth Amendment to have strengthened, not weakened, its protections.

I will argue, however, that Amar's argument is seriously flawed because it ignores the particular historical circumstances in which contemporary incorporation doctrine developed. For Amar, incorporation should be understood as simply putting into effect the intentions of the framers of the Fourteenth Amendment. In fact, the Supreme Court formulated the incorporation doctrine only after the New Deal rendered unusable earlier interpretations of the Fourteenth Amendment; accordingly, a full understanding of the Fourteenth Amendment's effect on the Bill of Rights - including the Second Amendment - must explain why the incorporation doctrine emerged only after the New Deal, and not before.

I then provide a brief start toward such an explanation by contrasting the rebirth of the First Amendment after the New Deal with the dormancy of the Second. I conclude by suggesting the need for further work by courts and scholars to give the Second Amendment meaning in the context of the post-New Deal Constitution.

\section{THE Founders' VISION OF THE SECOND AMENDMENT}

For the Founders, the Second Amendment was primarily about the allocation of military power..$^{30}$ The genesis of the Amendment lay in

29. See AMAR, supra note 9.

30. Throughout this Article, I will attribute various beliefs to "the Founders." The eminent historian Michael Bellesiles has pointed out to me that such language implies a unity of ideology among the men who drafted and ratified the Constitution and the Bill of Rights not to mention the citizens who those men claimed to represent - that simply did not exist. I certainly do not mean to obscure the endlessly fascinating diversity of views within this group. See generally, e.g., SAUL CORNELL, THE OTHER FOUNDERS (1999) (describing competing strands of political theory within the beliefs of both Federalists and Anti-Federalists). I nonetheless think that reducing the historical complexity to simple statements of the form "The Founders believed ..." is not only justifiable shorthand, but is necessary for constitu- 
one of the most contentious issues faced by the Philadelphia Convention: whether the national government should have an army or rely instead on state-based militia. ${ }^{31}$ Characteristically, the Founders reached a complex and ingenious compromise in which both the federal army and the states' militia were assigned carefully delineated roles. The purpose of the Second Amendment was to protect that compromise.

\section{A. The Roles of the Army and the Militia in the Founders' Political Theory}

The Founders' view of military power was built on a dichotomy between armies and militias. In this ideology, the two institutions differed along a range of social and political dimensions. ${ }^{32}$ First, armies consisted of full-time, professional soldiers - "permanent corps in the pay of the government." 33 Militiamen, on the other hand, were citizensoldiers, men who owned weapons, trained periodically and stood ready to defend their' country if necessary. Second, armies were composed wholly of hirelings attracted by decent wages, or fortuneseekers in search of plunder. Militia service, by contrast, was a compulsory obligation of citizenship imposed across society, although men were typically permitted to provide a substitute or pay a fee to avoid service. ${ }^{34}$ Third, and crucially for the Founders' experiment in federalist democracy, armies served the highest level of government - the Crown in England, or the national government in the soon-to-beUnited States. Militias, on the other hand, were associated with local political structures - the nobility in England, or the states here. Akhil Amar succinctly summarizes the Founders' understanding: A militia unit was "a randomly conscripted cross-section of the general militia (all citizens capable of bearing arms) ... serving alongside their fami-

tional interpretation - at least for those who believe, as I do, that constitutional interpretation must be constrained by what Justice Scalia has termed the "objectified' intent" of the Constitution. See SCALIA, supra note 11, at 17.

31. No fewer than eight of the Federalist Papers are devoted in whole or in part to defending the Philadelphia Convention's decision to authorize Congress to "raise and support Armies.” See THE FEDERALIST Nos. 8, 23, 24, 25, 26, 28 (Alexander Hamilton), Nos. 41, 46 (James Madison).

32. For good descriptions of the Founding-era military, see JOHN WHITECLAY Chambers II, To RaISE AN ARMY: THE DRAFT COMES TO MODERN AMERICA 13-30 (1987); JOHN K. MAHON, HistORY OF THE MILITIA AND THE NATIONAL GuARD 1-62 (1983); Charles Royster, A Revolutionary People at WaR: The Continental ARMY AND AMERICAN CHARACTER, 1775-1783 (1979).

33. THE FEDERALIST No. 24, at 161 (Alexander Hamilton) (Clinton Rossiter ed., 1961).

34. See CHAMBERS II, supra note 32, at 13-30; MAHON, supra note 32, at 1-62; Alan Hirsch, The Militia Clauses of the Constitution and the National Guard, 56 U. CIN. L. REV. 919, 940 n.116 (1988) ("The Constitution recognized two military forces: the militia and the regular army. Service in the militia was compulsory at the time of the Constitution, whereas the regular army was to be raised by enlisting volunteers."). 
lies, friends, neighborhoods, classmates and fellow parishioners." 35 Army enlistees, "full-time soldiers who had sold themselves into virtual bondage to the government, were typically considered the dregs of society - men without land, homes, families, or principles. ${ }^{.36}$

Recent historical research has challenged some aspects of this portrait. Even at the time, it turns out, the Founders' vision of the militia contained a significant element of romanticized myth. Michael Bellesiles has convincingly demonstrated that the colonial militias were poorly armed, ill-trained and unreliable. ${ }^{37}$ Saul Cornell has shown that militia eligibility was far from universal, and actual participation even less so. ${ }^{38}$ Pennsylvania, for example, made militia service contingent on acceptance of a rigorous loyalty oath; this requirement rendered "as much as forty percent of the citizenry" ineligible..$^{39}$ Moreover, the ability of wealthier citizens to pay others to substitute for them meant that, in practice, militiamen were drawn disproportionately from the poorer segments of the population, making the actual composition of the militia closer to that of the army than the Founders' ideal-types would suggest. ${ }^{40}$ Popular belief would have it that the colonists won the Revolutionary War with militia - King George had Hessian mercenaries, we had patriotic farmboys - but as the conflict dragged on, the Continental Army came increasingly to rely on full-time soldiers. ${ }^{41}$ By Yorktown, militiamen constituted barely a third of the victorious American forces. ${ }^{42}$

\section{AMAR, supra note 9 , at 53,55 .}

36. Id. at 53.

37. Bellesiles' study of probate records show that fewer than fifteen percent of probate inventories from the period 1765-1790 listed firearms; as these probate inventories were generally exhaustive, and as they describe the possessions of wealthier males - precisely the people most likely to own firearms - they suggest an overall level of gun ownership below ten percent. See Michael Bellesiles, Gun Culture, supra note 3, at 426-28. Bellesiles' estimates are confirmed by other contemporaneous data. See id. at 428-32, 438-47. Bellesiles also demonstrates that many firearms in circulation during this period were either permanently nonfunctional or were kept in a state of disrepair such that making them functional would require substantial effort, and that militiamen typically trained only one day a year and were often poor marksmen. See id. at 433-38; see also Michael Bellesiles, Gun Laws, supra note 3; Michael Bellesiles, Suicide Pact, supra note 3.

38. See Cornell, supra note 3.

39. Id. at 228.

40. See ChAmbers II, supra note 32, at 20-21; ERIC FONER, TOM PAINE AND REVOLUTIONARY AMERICA 63-66 (1976); MAHON, supra note 32, at 19, 37-38.

41. See CHAMBERS II, supra note 32, at 21-22 ("the rank and file of the Continental Army ... eventually became composed overwhelmingly of the young and the poor whites and blacks - the sons of marginal farmers, laborers, drifters, indentured servants - and recent immigrants without roots in America"); see also ROYSTER, supra note 32, at 37 ("Early in the war some revolutionaries argued that the militia, which had proven its competence at Lexington and Bunker Hill, could sustain a large part of the resistance to the British. By late 1776, little attachment to this idea remained.").

42. See MAHON, supra note 32, at 41 . 
Yet while this research deepens our understanding of the realities underlying the Founders' political theory, it is nonetheless clear that the army/militia dichotomy was a fundamental part of that theory. ${ }^{43}$ The debates over the Constitution's military provisions were framed entirely around the concepts of "militia" and "army." This conceptual framework was orthodoxy in the intellectual tradition that informed so much of the Founders' thinking. For example, in The Wealth of $\mathrm{Na}$ tions, published in 1776, Adam Smith wrote: "In a militia, the character of the labourer, artificer, or tradesman, predominates over that of the soldier: in a standing army, that of the soldier predominates over every other character." ${ }^{14}$ Or as the Richmond Enquirer put it in 1812, contrasting a regiment of Virginia militiamen marching off to battle with army units: "This company is composed not of the dregs of society, culled from the by-lanes \& alleys of the town, but of the flower of our youth and the best blood of our country.... They have left the caresses of friends, and the soft repose of their private life, to tread the snows of Canada and the inhospitable wilds of the Savage." 45

Most important, while the research of Bellesiles and Cornell does show that the Founders' theory of the militia was hyperbolic, it does not erase the underlying factual basis for the Founders' conceptual distinction between militia and army. ${ }^{46}$ Militia membership was much more widespread and distributed throughout society than army service. In essence, the militia was an arm of the community, while the army was an arm of the government.

\section{B. The Military Clauses of the Original Constitution}

Given their conceptual dichotomy, the drafters of the Constitution had three options available to them: "We must either empower [Con-

43. Cf. CHAMBERS II, supra note 32, at 15 ("Even as it atrophied as a fighting system, however, the militia remained important as a politico-military concept."); RoYsTER, supra note 32, at 360 (arguing that even though the Revolutionary War was fought and won largely by professional soldiers rather than militiamen, the Founding generation retained its ideological hostility to standing armies and preference for militia: "The popular interpretation of victory in the Revolutionary War rejected the officers' pretensions, abolished the army, and in doing so restored the citizens to their original and vital stature as the pillars of America's future glory.").

44. 2 AdAM SMITH, AN INQUIRY INTO THE NATURE AND CAUSES OF THE WEALTH OF NATIONS 698 (R.H. Campbell, A.S. Skinner, \& W.B. Todd eds., Clarendon Press 1976). On the influence of Adam Smith in particular on the Founders, see FONER, supra note 40, at 153-58.

45. Lee A. Wallace, JR., The Petersburg Volunteers, 1812-1813, 82 VA. Mag. OF HIST. \& BIOGRAPHY 460 (1974).

46. In a recent, short article, Edmund Morgan suggests that the discrepancy between the actual strength of the militia and its ideological significance is explained by Founding-era Americans' desire to identify themselves with the British yeomanry, and to distinguish themselves from the French. See Edmund Morgan, In Love with Guns, N.Y. REV. BoOKs, Oct 19, 2000 , at 30 . 
gress] to employ, and rely altogether on, a standing army; or depend altogether on militia; or else we must enable them to use the one or the other of these two ways, as may be found most expedient." $47 \mathrm{Re}$ viewing the debates surrounding the drafting and ratification of the Constitution reveals a clear consensus that they found the latter option - reliance on a combination of an army and the militia - the most desirable. While a diversity of views existed among the Founders, there was broad agreement on three main points: (1) from the point of view of democratic theory, militia were clearly superior to an army; (2) from a military perspective, however, an army was clearly superior to militia; (3) therefore, while the Constitution should give Congress power to employ an army when necessary, states should continue to maintain militia as an alternative - and counterweight - to any federal army that might be established.

\section{The Dangers of a National Army}

A core belief of the Founders, shared by Federalists and AntiFederalists alike, was that "standing armies are dangerous to liberty."48 The main fear was that a would-be tyrant might use a standing army to impose his will on the nation by force. In the words of a group of leading Pennsylvania Anti-Federalists:

A standing army ... may be made a fatal instrument to overturn the public liberties; it may be employed to enforce the collection of the most oppressive taxes, and to carry into execution the most arbitrary measures. An ambitious man who may have the army at his devotion, may step up into the throne, and seize upon absolute power. ${ }^{49}$

47. 3 The Debates in the Several State Conventions on the Adoption of the Federal Constitution, as Recommended by the General Convention at PHILADELPHIA IN 1787, at 389 (Jonathan Elliot ed., 2d ed. 1866) (statement of George Nicholas) [hereinafter ELLIOT'S DEBATES].

48. THE Federalist No. 29, at 183 (Alexander Hamilton) (Clinton Rossiter ed., 1961). See also 2 THE RECORDS OF THE FEDERAL CONVENTION OF 1787, at 329 (Max Farrand ed., 1911) (statement of Elbridge Gerry) [hereinafter FARRAND]; RICHARD H. KOHN, EAGLE AND SWORD: THE FEDERALISTS AND THE CREATION OF THE MILITARY ESTABLISHMENT IN AMERICA, 1783-1802, at 2 ("No principle of government was more widely understood or more completely accepted by the generation of Americans that established the United States than the danger of a standing army in peacetime."); ROYSTER, supra note 32, at 35 ("The political ideology that Americans adapted from the English Commonwealth writers warned that a standing army in time of peace was an engine of oppression.").

49. 3 THE COMPlete ANTI-FEderalist 164 (Herbert J. Storing, ed. 1981) (statement by Pennsylvania minority) [hereinafter THE COMPLETE ANTI-FEDERALIST]; see also 2 id. at 375 ("as standing armies in time of peace are dangerous, they are not to be kept up") (Brutus II, New York Journal, Nov. 1, 1787); id. at 409 ("standing armies in times of peace... generally prove the destruction of the happiness and liberty of the people") (Brutus IX, Jan. 17, 1788); 3 ELLIOT'S DEBATES, supra note 47, at 380 ("But when once a standing army is established in any country, the people lose their liberty.") (statement of George Mason at Virginia ratifying convention); 3 id. at 389 ("If a standing army were alone to be employed, such an army must be kept up in times of peace as would be sufficient in times of war. The dangers of such an army are so striking that every man would oppose the 
Less obviously, but just as important, many Founders believed that a president would be easily tempted to use a standing army promiscuously in pursuit of empire and personal glory, thus bankrupting the nation and placing it at military risk. A citizen militia, by contrast, would be much more resistant to adventurism. First, any attempt to use the militia in cases other than genuine emergencies would meet stiff popular resistance. Second, because militia units were state, rather than national, entities, calling them forth would require the cooperation of state governors - or at least would present governors with opportunities to challenge a President's decision to make war. For the Founding generation, the prime example of the militia as a vehicle for local opposition to imperial warmaking was the Seven Years' War, when numerous militia units throughout New England refused to obey the Crown's call to serve - disobedience that was supported in Connecticut, at least, by the colonial governor himself. ${ }^{50}$ Forcing the federal government to rely on state militias would have fit beautifully with the Founders' guiding principle of checks and balances.

Finally, even during times of peace, a standing army would be terribly expensive, necessitating ruinous taxation. The Federalist Papers repeatedly base their argument for ratification on the ground that disunited colonies would each be forced to provide for their own defense and would need to be constantly on guard against their neighbors, thus "present[ing] liberty everywhere crushed between standing armies and perpetual taxes." 51

\section{The Need for a National Army}

Driven by these concerns, the drafters of the Articles of Confederation had made no provision for a national army; instead, the Articles had authorized Congress only to determine an overall number of troops to be raised in the event of military necessity, and to make requisitions on the states for their shares.

Some delegates wanted to continue that structure, ${ }^{52}$ others sought to prohibit federal armies in peacetime, or to limit any such armies to

adoption of this government, had it been proposed by it as the only means of defence.") (statement of George Nicholas). (1992).

50. Gordon S. WOOd, THE Radicalism of THE AMERICAN Revolution 163-64

51. THE Federalist No. 41, at 258 (James Madison) (Clinton Rossiter ed., 1961). See also id. at 260 (a standing army is "burdensome to the properties and ominous to the liberties of the people"); George Washington, Sentiments on a Peace Establishment, 3 THE FOUNDERS' CONSTITUTION 128-29 (Philip B. Kurland \& Ralph Lerner eds., 1987) ("[W]e are too poor to maintain a standing Army adequate to our defence, and were our country more populous and rich, still it could not be done without great oppression of the people."); 4 THE COMPLETE ANTI-FEDERALIST, supra note 49, at 207 ("An army, either in peace or war, is like the locust and caterpillars of Egypt; they bear down all before them.").

52. See, e.g., 1 FARRAND, supra note 48 , at 242 (New Jersey plan). 
a specified size. ${ }^{53}$ But to most of the Founders, the military provisions were among the Articles' signal weaknesses. Indeed, when Governor Edmund Randolph of Virginia opened the Convention by "enumerat[ing] the defects" of the Articles, he began with: "that the confederation produced no security agai[nst] foreign invasion; congress not being permitted to prevent a war nor to support it by th[eir] own authority. $" 55$

The delegates, many of whom had fought in the Revolutionary War, recognized that in the event of war with a European power, a professional army would almost certainly be needed. ${ }^{55}$ Too, westward expansion would lead inevitably to conflicts with Native Americans, thereby requiring at least "a certain number of troops for guards and garrisons." $" 56$ For none of these purposes would the militia suffice.

The Founders may have idealized the militia in some respects, but they well understood its military limitations. The debates in Philadelphia and the ratifying conventions are full of sardonic references to the woeful state of the militia. ${ }^{57}$ As George Washington himself put it in a letter to the Continental Congress in the midst of the war:

To place any dependence upon Militia, is, assuredly, resting upon a broken staff. Men just dragged from the tender scenes of domestic life; unaccustomed to the din of arms; totally unacquainted with every kind of military skill ... [are] timid and ready to fly from their own shadows. Besides, the sudden change in their manner of living ... produces shameful, and scandalous desertions ... Certain I am, that it would be cheaper to keep 50,000 or 100,000 men in constant pay than to depend upon half the number, and supply the other half occasionally by militia ....58

53. See, e.g., 2 id. at 329-30 (statement of Elbridge Gerry); id. at 326 (statement of George Mason).

54. 1 id. at 19.

55. See 3 ELLIOT'S DEBATES, supra note 47, at 424-25 ("The safety of the Union and particular states requires that the general government should have power to repel foreign invasions.") (statement of James Madison); $4 \mathrm{id}$. at 98-99 (arguing that danger of British invasions is not over, and that an army is needed to repel foreign invasions) (statement of $\mathrm{Mr}$. Iredell); THE FEDERALIST No. 26, at 170 (Alexander Hamilton) (Clinton Rossiter ed., 1961); THE FEDERALIST No. 4 (John Jay) (arguing that trade and other relations with European nations could lead to war).

56. THE FEDERALiST No. 26, at 170 (Alexander Hamilton) (Clinton Rossiter ed., 1961).

57. See, e.g., 3 ELLIOT'S DEBATES, supra note 47, at 389 ("Were we to be invaded by a powerful, disciplined army, should we be safe with militia? Could men unacquainted with the hardships, and unskilled in the disciplines of war ... encounter with success the most skillful veterans... ?") (statement of George Nicholas); 2 id. at 522 ("How powerful and respectable must the body of militia appear under general and uniform regulations! How disjointed, weak, and inefficient are they at present!") (statement of James Wilson); 5 id. at 465 ("The states neglect their militia now. ...") (statement of James Madison); 2 id. at 387 ("Have we not found from experience, that, while the power of arming and governing the militia has been solely vested in the state legislatures, they were neglected and rendered unfit for immediate service?") (statement of James Madison).

58. The Gun CONTRol Debate: A Documentary History 12 (Marjolijn Bijlefeld ed., 1997) (reprinting letter dated September 24, 1776, from George Washington to the 
The very characteristics that made the militia attractive from the point of view of democratic theory posed serious liabilities from the point of view of military efficacy: unprofessionalism, regional nonuniformity, strong ties to their home communities, and even local control. Debating at the Philadelphia Convention, Edmund Randolph "observ[ed] that the Militia were every where neglected by the State Legislatures, the members of which courted popularity too much to enforce a proper discipline." 59 In sum, the Founders saw armies as potentially dangerous but probably necessary.

\section{The Founders' Solution: State Militia as Both Alternative and Counterweight to a National Army}

The Founders' solution to this problem was characteristically complex and structural. Congress would have power "to raise and support Armies," ${ }^{60}$ but the states would continue to maintain militia, which would be available to the federal government when needed "to execute the Laws of the Union, suppress Insurrections and repel Invasions." $" 1$

Maintaining an able militia would mitigate the dangers of a standing army in two ways. First, the availability of the militia would diminish the need for the federal government to establish an army: "As the greatest danger to liberty is from large standing armies, it is best to prevent them by an effectual provision for a good Militia." 62

Second, if the unthinkable were to happen, and the federal government did indeed overstep its constitutional boundaries, relying on its army to quell opposition, the state militia would be there to resist. James Madison explained this in a famous passage from Federalist No. 46:

Let a regular army, fully equal to the resources of the country, be formed; and let it be entirely at the devotion of the federal government: still it would not be going too far to say that the State governments with the people on their side would be able to repel the danger. The highest

President of the Continental Congress); see also 2 FARRAND, supra note 48, at 332 ("Mr. [Charles Cotesworth] Pinkney... had however but a scanty faith in Militia. There must be (also) a real military force.... The United States had been making an experiment without it, and we see the consequences in their rapid approaches toward anarchy.")

59. 2 FARRAND, supra note 48 , at 387.

60. U.S. CONST. art. I, $\$ 8$, cl. 12 .

61. U.S. CONST. art. I, $\S 8$, cl. 15 .

62. 2 FARRAND, supra note 48, at 388 (statement of James Madison); see also 3 id. at 318-319 ("If insurrections should arise, or invasions should take place, the people ought unquestionably to be employed to suppress and repel them, rather then a standing army. The best way to do these things, was to put the militia on a good and sure footing, and enable the government to make use of their services when necessary....") (statement of Alexander Hamilton). 
number to which, according to the best computation, a standing army can be carried in any country does not exceed one-hundredth part of the whole number of souls; or one twenty-fifth part of the number able to bear arms. This proportion would not yield, in the United States, an army of more than twenty-five or thirty thousand men. To these would be opposed a militia amounting to near half a million of citizens with arms in their hands, officered by men chosen from among themselves, fighting for their common liberties and united and conducted by governments possessing their affections and confidence. It may well be doubted whether a militia thus circumstanced could ever be conquered by such a proportion of regular troops. . . . Besides the advantage of being armed, which the Americans possess over the people of almost every other nation, the existence of subordinate governments, to which the people are attached and by which the militia officers are appointed, forms a barrier against the enterprises of ambition, more insurmountable than any which a simple government of any form can admit of. ${ }^{63}$

Indeed, the very presence of the militia would deter power-hungry federal officials from even entertaining such schemes.

These two purposes for the militia - both alternative and counterweight to a federal army - were somewhat in tension. On one hand, if they are to serve as an alternative to an army, the militia should be readily available to the federal government. On the other hand, subjecting the militia too much to federal authority could lessen their utility as a counterweight - or possibly even transform the militia itself into a federal standing army.

Accordingly, the intricate militia clauses in Section 8 of Article I received considerable attention at the Philadelphia Convention. To ensure that the militia would effectively substitute for an army, the drafters gave Congress authority to "provide for organizing, arming and disciplining the Militia." 64 Some delegates feared this gave the federal government too much control. The prevailing view, however, was that federal regulation of militia training was necessary for the militia to be a reliable military force; without federal oversight, the militia would remain ragtag and incoherent, and the national government would be forced to turn to an army. ${ }^{65}$

At the same time, the drafters made sure that the militia would remain fundamentally state, rather than federal, institutions. Most prominently, the provision for "calling forth" the militia envisioned a

63. The Federalist No. 46, at 299 (James Madison) (Clinton Rossiter ed., 1961). This passage nicely captures the distinction between the federal government's army and the states' militia. Militia officers are to be selected by the states, and Madison unquestioningly assumes that the militiamen will be "attached to" the states. Note, too, the subtle brilliance with which Madison contrasts army "men" with militia "citizens." See also infra text accompanying note 204 (noting that Madison's argument assumes an enlisted army and a conscripted militia).

64. U.S. ConsT. art. I, § 8, cl. 16.

65. See supra note 59 and accompanying text. 
federal requisition upon the states. The federal government was given operational control to "govern[]" only "such Part of [the Militia] as may be employed in the Service of the United States," and only during periods of "actual service" to the federal government. ${ }^{66}$

The delegates also explicitly "reserv[ed] to the States respectively, the Appointment of the Officers, and the Authority of training the Militia according to the discipline prescribed by Congress." 67 James Madison's proposal to permit the federal government to appoint senior militia officers was met with outrage: "Let us at once destroy the State Govts have an Executive for life or hereditary, and a proper Senate, and then there would be some consistency in giving [this power] to the Genl Govt." ${ }^{\prime 68}$

The point is driven home further in Article II, where the President is denoted "Commander in Chief of the Army and Navy of the United States, and of the Militia of the several States, when called into the actual Service of the United States." Army and Navy and the state Militia is clear. Even when undertaking national tasks under the direction of the President, the militia remain "of the several States."

\section{The Framing of the Second Amendment}

Many Anti-Federalists, however, were not satisfied with the plan crafted by the Philadelphia drafters. In the conventions called to ratify the Constitution, and in pamphlets circulated to influence those conventions, Anti-Federalists blasted the proposed central government as too powerful. The military provisions - the Armies clause and both of the militia clauses - were among the greatest sources of controversy.

Anti-Federalists raised a number of specific objections to the proposed constitution's military provisions. First, as in Philadelphia, some sought direct limits on Congress' power to raise armies, such as a supermajority requirement for congressional approval, ${ }^{70}$ or a numeric limit on the size of any federal army. ${ }^{71}$ But again, considerations of military necessity made these proposals unacceptable.

66. U.S. CONST. art. I, § 8, cl. 16.

67. Id.

68. 2 FARRAND, supra note 48 , at 388 (statement of Elbridge Gerry).

69. U.S. CONST, art. II, 82 , cl. 1 .

70. See, e.g., 2 THE COMPLETE ANTI-FEDERALIST, supra note 49, at 243 (reprinting letter from "The Federal Farmer"); 2 ELLIOTT'S DEBATES, supra note 47, at 406 (proposal of Mr. Lansing that raising of peacetime army require congressional supermajority); see also 1 $i d$. at 88 (proposal by New Jersey ratification convention that assent of nine states be required for peacetime army).

71. See, e.g., 2 THE COMPLETE ANTI-FEDERALIST, supra note 47, at 58 (reprinting Luther Martin's “The Genuine Information Delivered to the Legislature of the State of 
Next, the Anti-Federalists turned their attention to the militia clauses. The Calling Forth clause, some argued, was too expansive, and would create innumerable opportunities to call forth the militia on the pretext of a necessity to "execute the laws." In part, the concern was that militiamen would be mistreated. Luther Martin declared that "Congress will have the power, if they please, to march the whole militia of Maryland to the remotest part of the Union, and keep them in service as long as they think proper... [and the militiamen] may, during such service, be subjected to military law, and tied up and whipped at the halbert, like the meanest of slaves." ${ }^{\prime 2}$ But the deeper concern evoked the fear of standing armies: By making militia service onerous, George Mason argued, the federal government "would harass the people so much that they would agree to abolish the use of the militia, and establish a standing army." ${ }^{173}$ At least some federal uses of the militia, the Anti-Federalists argued, should be made subject to state consent. ${ }^{74}$

Federalist supporters of the Constitution were unmoved by these arguments. The best security against a standing army, the Federalists argued, was to make the militia as available as possible to the federal government - that way, the temptation to maintain a peacetime army would be minimized. ${ }^{75}$

The Anti-Federalists made a separate and more powerful objection to Congress' power to "provide for organizing, arming, and disciplining" the militia. Here, some Anti-Federalists characterized this as an "exclusive right" of Congress. Once again, the force of the complaint came from an underlying fear of standing armies. George Mason forecast that the federal government would "neglect [the militia], and let them perish, in order to have a pretence of establishing a standing army.",76

The Federalist response to this objection was to deny that Congress' powers were exclusive - if the federal government failed to ensure a well-prepared militia, the states could certainly do so on their own. Notably, this response focused solely on correct interpretation of

Maryland Relative to the Proceedings of the General Convention Lately Held at Philadelphia"); id. at 416 (reprinting "Essays of Brutus").

72. 1 ELLIOT's DeBates, supra note 47, at 371. See also 3 id. at 378 (statement of George Mason) (arguing that the federal government might call up the Georgia militia to respond to a disturbance in New Hampshire).

73. 3 id. at 378 (statement of George Mason).

74. See, e.g., 2 id. at 406 (proposal of Mr. Lansing).

75. See 3 id. at 392 ("If you give [power to call forth the militia] not to Congress, it may be denied by the states. If you withhold it, you render a standing army absolutely necessary; for if they have not the militia, they must have such a body of troops as will be necessary for the general defence of the Union.") (statement of George Nicholas).

76. $3 \mathrm{id}$. at 379 (statement of George Mason). 
the constitutional text rather than any substantive disagreement. As to the principle underlying the Anti-Federalist objection - that states must have the ability to arm and train their militia - the Federalists agreed completely. Thus when the Federalists decided a Bill of Rights was necessary to address a host of Anti-Federalist concerns, the AntiFederalist proposal for a right to keep and bear arms was unproblematic (unlike proposals to limit Congress' power to raise armies or deploy the militia). As any draftsperson knows, when two parties negotiating a document agree on a principle, but one side feels that the text of the document does not express the principle clearly enough, the other side rarely finds it worthwhile to insist on the adequacy of the text; the usual solution is to make the document clearer still. Similarly, the Anti-Federalist proposal of a Second Amendment was easily understood as strengthening language in the original Constitution specifically, Article I, Section 8, Clauses 15 and $16 .^{77}$ The Second Amendment functioned with respect to these provisions just as the Tenth Amendment did with respect to Article I, Section 8 generally it was an affirmation that only certain, specifically described powers had been granted to the federal government, and that residual power remained with the states.

The depth of the Founders' concern to ensure state control of the militia - a concern shared by both Federalists and Anti-Federalists is shown in the debates in the First Congress concerning what became the Second Amendment. Congressional consideration of the Bill of Rights began with a resolution offered by James Madison containing the following proposed amendment: "The right of the people to keep and bear arms shall not be infringed; a well armed, and well regulated militia being the best security of a free country: but no person religiously scrupulous of bearing arms, shall be compelled to render military service in person." 78 irtually all of the debate over this proposal focused on the third clause - the conscientious objector provision. Elbridge Gerry, the leading Anti-Federalist voice among the congressional drafters, argued that the proposed clause would give the federal

77. Note, too, that the actual debates between Federalists and Anti-Federalists focused not so much on the specter of the federal government prohibiting citizens to arm themselves, but on the fear that neither the federal government nor the states would actively arm citizen militiamen. This accords perfectly with the findings of recent historical scholarship that arms ownership in the Founding period was expensive, difficult, and not at all widespread. See Bellesiles, Gun Culture, supra note 3. For the Founders' delicate balance to work, it would not be sufficient for government merely to permit arms ownership; rather, government needed actively to foster arms ownership. The revisionists turn this history on its head - the Founders' main fear was not that the federal government would disarm militiamen, but that it would fail to arm them.

78. Creating the Bill of Rights: The Documentary Record From THE First FEDERAL CONGRESS 12 (Helen E. Veit, Kenneth R. Bowling \& Charlene Bangs Bickford eds., 1991) (hereinafter DOCUMENTARY RECORD) (resolution offered in the House of Representatives by James Madison on June 8,1789 ). 
government too much authority to determine militia eligibility, a prerogative properly left to the states:

Now I am apprehensive, sir, that this clause would give an opportunity to the people in power to destroy the constitution itself. They can declare who are those religiously scrupulous, and prevent them from bearing arms. What, sir, is the use of a militia? It is to prevent establishment of a standing army, the bane of liberty. Now it must be evident, that under this provision, together with their other powers, congress could take such measures with respect to a militia, as make a standing army necessary. ${ }^{79}$

Other representatives agreed ${ }^{80}$ and the provision was dropped.

Congress' other drafting changes are also illuminating. Madison's original version had declared a well-regulated militia to be "the best security of a free country." First, Congress replaced "the best" with "necessary to the," underscoring the Founders' profound distrust of standing armies. As Elbridge Gerry put it: "A well-regulated militia being the best security of a free state, admitted an idea that a standing army was a secondary one." ${ }^{.11}$ Next, Congress replaced "country" with "State," eliminating any possible suggestion that the militia were to be considered national entities, and highlighting their role in protecting the states against the possibility of an overweening federal government. ${ }^{82}$ The core concern of the Second Amendment, reflected in both of these changes, was protecting the delicately balanced military structure envisioned by the Founders - an army constitutionally available, but obviated by a well-prepared, state-based militia. ${ }^{83}$

\section{Second Amendment Practice in the Founding Period}

For the first several decades after ratification, the military structure set in place by the Founders functioned much as they had intended. The initial test of the system came in 1794 with the Whiskey Rebellion in western Pennsylvania. Although the federal government had by this time established an army of approximately 3,500 soldiers ${ }^{84}$ (actually, it had simply assumed command of the army raised under

79. Id. at 182 (statement of Elbridge Gerry).

80. See id. at $182-84$.

81. Id. at 184 (reprinting The Congressional Register, August 17, 1789).

82. The change from "country" to "State" was made by a select committee charged by the House with revising Madison's proposal. See id. at 30 . This committee left no surviving records of its deliberations. My characterization of the change is based solely on inference from the words themselves.

83. The only other change Congress made to Madison's original draft of the Amendment was to reverse the order of the clauses, pushing the "well regulated militia" language to the front of the sentence. The change is minor, but it, too, arguably highlights Congress' intention that the Amendment prevent threats to the militia, and not to arms ownership generally.

84. See КонN, supra note 48 , at 149. 
the Articles of Confederation), ${ }^{85}$ this force was deemed too small to suppress the insurrection, and in any event it was engaged fighting $\mathrm{Na}$ tive Americans elsewhere along the frontier. Accordingly, President Washington called forth militia from Maryland, New Jersey, Pennsylvania, and Virginia. ${ }^{86}$ As the Founders had hoped, the President's first recourse was not to an army, but rather to the militia.

Even this relatively minor episode, though, illustrated tensions within the Founders' plan. On the plus side - for the federalist system, if not for the national government - federal reliance on militia gave states a genuine voice in military policy. In return for the cooperation of Governor Thomas Mifflin in mobilizing Pennsylvania's militia, Washington reluctantly postponed a military response for several weeks to permit continued negotiation with the rebels. ${ }^{87}$

On the other hand, the Founders' skepticism about the reliability of the militia proved well-founded. The states encountered serious difficulty raising the 13,000 men requested by Washington.$^{88}$ In several areas, militiamen called into service refused to comply; in Maryland, militiamen "beat their officers from the field." were poorly disciplined and deserted in high numbers. ${ }^{90}$ In the end, though, the force was assembled and the (fortunately insubstantial) insurrection defeated; having done their duty, the militiamen returned home.

Soon thereafter, however, the War of 1812 presented the Founders' system with a major challenge. The circumstances were just as the architects of the Second Amendment had feared. Now-President Madison (in an ironic illustration of his own observation that even great men cannot be trusted in positions of power) had pushed the country into war not to defend itself but to protect commercial shipping routes and to conquer Canada. ${ }^{91}$ This was precisely the sort of expensive, expansionist venture that the Founders' balance between the army and the militia was supposed to prevent. But if the Founders' system failed to prevent the war, their insights nonetheless proved correct. The Administration had great difficulty attracting volunteers and generating congressional support for the taxes needed to pay a volun-

85. See Act of Sept. 29, 1789, ch. 25, 1 Stat. 95.

86. See Thomas P. Slaughter, The WhiSkey Rebellion 3 (1986); see also Act of May 9, 1794, ch. 27, Stat. 367 (authorizing President to call forth militia).

87. See SLAUGHTER, supra note 86, at 196; see also KOHN, supra note 48, at 162.

88. See Slaughter, supra note 86, at 207-14.

89. Id. at 210; see also id. at 207-10.

90. See id. at 214-15. (1974).

91. See Alan Lloyd, The Scorching of Washington: The War of 1812 11-30 
teer army. ${ }^{92}$ In Connecticut and Massachusetts, the governors refused to comply with Madison's request for militia units on the ground that invading Canada did not qualify as a constitutionally legitimate purpose for calling forth the militia. ${ }^{93}$

The constitutional crisis came late in the war, when Madison proposed a draft (the actual author of the proposal was another leading Jeffersonian, future President James Monroe ${ }^{94}$ ). Opponents in Congress saw the proposal as fundamentally inconsistent with the Founders' vision. ${ }^{95}$ Conscription would remove a key element from the constitutional framework: the role of the states as intervening layers between the federal government and the citizen-soldiers. As Daniel Webster, leader of the opposition, argued, Madison's proposal amounted to "raising a standing army out of the militia by draft." 96 Webster continued with a thinly-veiled threat of resistance: "It will be the solemn duty of the State Governments to protect their own authority over their own militia, and to interpose between their citizens and arbitrary power. ${ }^{997}$

This was no idle warning. Following the precedent of the Virginia and Kentucky Resolutions in 1798, representatives from five states convened in Hartford to proclaim their opposition to Madison's policies, and in particular the draft. The Report and Resolutions of the Hartford Convention declared:

RESOLVED - That it be and hereby is recommended to the legislatures of the several states represented in this Convention, to adopt all such measures as may be necessary effectually to protect the citizens of said states from ... all acts ... subjecting the militia or other citizens to forcible drafts, conscriptions, or impressments, not authorised by the constitution of the United States.

92. See CHAMBERS II, supra note 32, at 32-34; MAHON, supra note 32, at 67-68; SAMUEL ELIOT MORRISON, THE OXFORD History OF THE AMERICAN PEOPLE 383-91 (1965).

93. See MAHON, supra note 32, at 67-68; MORRISON, supra note 92, at 383. Under Article I, $\S 8$, cl. 15 , the militia could be called forth only "to execute the Laws of the Union, suppress Insurrections and repel Invasions."

94. See James Monroe, Recommendations for a Federal Draft, in THE MILITARY DRAFT: SELECTED READINGS ON CONSCRIPTION 503-13 (Martin Anderson ed., 1982).

95. I follow Akhil Amar in using the War of 1812 draft controversy as an example of Second Amendment practice. See AMAR, THE BILL OF RIGHTS, supra note 9, at 57-58.

96. 1 PAPERS OF DANIEL WeBsTER 21 (Charles M. Wiltse ed. 1986). Ironically, it was Federalists like Webster who opposed the war and the draft and relied on these states' rights arguments. In later life, at least, Webster was an ardent nationalist. The Jeffersonian Democratic-Republicans who initiated and propelled the war were in many other ways ideological heirs of the Anti-Federalists. The war is thus a marvelous example both of how assuming power can change a party's ideology, and of how simple summaries of such an ideology are invariably misleading; in this case, the Jeffersonians' affinity for France and hostility toward England overrode their decentralizing impulse.

97. Id. at 30 . 
Resolved, That it be and hereby is recommended to the said Legislatures, to authorize an immediate and earnest application to be made to the government of the United States, requesting their consent to some arrangement, whereby the said states may, separately or in concert, be empowered to assume upon themselves the defence of their territory $\ldots .^{98}$

None of the conscription bills were enacted - and denied his conscripted army, Madison soon made peace. The key principles underlying the military clauses of Article I and the Second Amendment the balance between a federal army and state-controlled militia - had been confirmed. As Amar puts it, "The eventual republican triumph on this issue... should be as central a precedent for our Second Amendment as the 1800 triumph over the Sedition Act is for our First." 99

\section{EVAluAting THE REVISIONIST ARGUMENT}

I will resume the historical narrative shortly (at the risk of ruining the suspense, I can say now that the Founders' framework is in for some serious changes). But first, I want to pause to consider the revisionists' arguments in light of the history recounted in Part I.

As I stated at the outset, the revisionists have produced a large body of writing arguing that the Second Amendment creates an "individual right" to own guns, and criticizing contemporary courts for instead interpreting the Amendment as conferring a "collective right." The first step in evaluating these claims is to establish precisely what the claims are. That task is more difficult than one might suppose, as both the revisionists and the courts they are criticizing have presented their positions in confusing ways.

\section{A. The "Collective Rights" Red Herring}

Start with the courts. The essence of modern Second Amendment doctrine is that the Amendment prohibits only statutes which interfere with the "preservation or efficiency" of the states' militia. ${ }^{100}$ Some courts, in applying this doctrine, have referred to the Amendment as creating a "collective right"; ${ }^{101}$ one court has even referred to the Second Amendment right as being "held by the States." 102 The revisionists

98. Report and Resolutions of the Hartford Convention, in 2 GREAT ISSUES IN AMERICAN HISTORY 240 (Richard Hofstadter ed., 1958).

99. AMAR, supra note 9 , at 58.

100. See United States v. Miller, 307 U.S. 174, 177 (1939).

101. See, e.g., Love v. Pepersack, 47 F.3d 120, 124 (4th Cir. 1995); United States v. Warin, 530 F.2d 103, 106 (6th Cir. 1976); United States v. Johnson, 497 F.2d 548, 550 (4th Cir. 1974).

102. Hickman v. Block, 81 F.3d 98, 101 (9th Cir.), cert. denied, 519 U.S. 912 (1996). 
have ridiculed this terminology, suggesting it means that only states can challenge statutes under the Second Amendment. To the contrary, the revisionists insist, all rights are "held" by individuals.

They have a point - but not one that goes very far. Certainly, an individual plaintiff or defendant can raise a Second Amendment claim in the hope of invalidating a statute that harms the individual. In this trivial sense, all constitutional rights are "individual rights." Consider, for example, the enumerated powers doctrine. In the Emerson case, the defendant raised an enumerated-powers claim in addition to his Second Amendment claim; he argued that Congress lacked power under the Commerce Clause to prohibit persons subject to restraining orders from possessing guns. ${ }^{103}$ Suppose the Emerson Court had struck down the law on that basis rather than the Second Amendment (not an outlandish supposition in light of United States v. Lopez ${ }^{104}$ and United States $v$. Morrison ${ }^{105}$ ). Does that make the enumeration of powers an "individual rights" doctrine? Or put another way: Calling the enumeration of powers an "individual rights" doctrine tells us nothing about the real issue raised by Emerson's Commerce Clause claim, which is whether the challenged statute thwarts the governmental-structure purposes underlying the enumeration of powers.

Similarly, the mere fact that individual American citizens have standing to raise Second Amendment claims in court tells us nothing about the scope of the protection granted by the Amendment. Timothy Emerson of course had standing to rely on the Second Amendment in challenging the statute under which he was prosecuted. In that sense, the Second Amendment right is not a "collective right" — it is not "held by the States" — but it may well be a militiafocused right in that it protects Emerson only from statutes that interfere with the states' militia.

The revisionists' focus on the standing issue is a red herring. ${ }^{106} \mathrm{It}$ obscures the real issue in their dispute with the courts, which is about

103. United States v. Emerson, 46 F. Supp.2d 598, 599-600 (N.D. Tex. 1999).

104. 514 U.S. 549 (1995) (holding that Congress lacked authority under Commerce Clause to enact provision of Gun Free School Zones Act).

105. United States v. Morrison, 120 S. Ct. 1740 (2000) (holding that Congress lacked authority under Commerce Clause to enact provision of Violence Against Women Act ).

106. Well, maybe not a pure red herring. At least one federal court has employed the militia-focused approach as a standing argument. See Hickman v. Block, 81 F.3d 98, 102 (9th Cir. 1996) ("Because the Second Amendment guarantees the rights of the states to maintain armed militia, the states alone stand in the position to show legal injury when this right is infringed."). Perhaps Hickman simply demonstrates that critics of standing doctrine are right to claim that its injury requirement is circular, and that court decisions dismissing complaints for lack of standing are equivalent to dismissals for failure to state a claim. Cf. Steven L. Winter, The Metaphor of Standing and the Problem of Self-Governance, 40 STAN. L. REV. 1371,1373 (1988) (describing and rejecting argument that standing doctrine is "a sophisticated manipulation for the sub rosa decision of cases on their merits"). But to those who do 
the scope of the Second Amendment right, and not about who can seek its vindication.

\section{B. The Libertarian Red Herring}

Once this issue is clearly stated, we can begin to focus on the revisionists' and the courts' differing understandings of the scope of the Second Amendment right. The revisionists typically posit a simple dichotomy between their "individual rights" approach to the Amendment and the modern courts' militia-focused approach. In truth, however, there are strong and weak versions of the revisionists' "individual-rights" approach, and their implications differ significantly.

The strong version is essentially libertarian; it sees the right to keep and bear arms as akin to the First Amendment rights of free speech and conscience - a fundamental aspect of individual autonomy the infringement of which is per se tyrannical. ${ }^{107}$ The libertarian Second Amendment right is sometimes derived from trivial autonomy interests such as an individual's ability to hunt or to engage in recreational shooting, but at its core is the assuredly nontrivial interest in self-defense. The notion is that a government that forces its citizens to remain defenseless against bullies and predators is no better than a government that itself subjects its citizens to "unreasonable" searches and seizures. It is this version of the revisionists' argument, which I will call the "Libertarian Approach," that was adopted by the Emerson Court ${ }^{108}$ and suggested by Justice Thomas in his Printz concurrence. ${ }^{109}$

The Libertarian Approach may have philosophical appeal, but the history recounted in Part I renders it highly implausible as constitutional interpretation. ${ }^{110}$ The revisionists' main argument for ignoring

distinguish between standing requirements and the other elements that a plaintiff must demonstrate in order to obtain relief, I suggest that Hickman was incorrect, and that accepting a militia-focused approach to the Second Amendment does not entail dismissing any suit brought by an individual citizen under the Second Amendment for lack of standing. For an example of a revisionist scholar presenting the militia-focused approach as a standing argument, see AMAR, supra note 9, at 221.

107. For examples of revisionist scholarship adopting this view, see Dowlut, supra note 3; Lund, supra note 3.

108. United States v. Emerson, 46 F. Supp. 2d 598, 600 (N.D. Tex. 1999).

109. Printz v. United States, 521 U.S. 898, 938 (1997) (Thomas, J., concurring).

110. In addition to its inconsistency with the specific legislative history we have discussed, the Libertarian Approach suffers from a more basic anachronism. It ignores the findings of historians such as Bernard Bailyn, Gordon Wood and J.G.A. Pocock, who have shown that the Founders' political theory was deeply republican. See BERNARD BAILYN, The IdEological ORIgins of THE AMERICAN REVOLUTION (1992); J.G.A. POCOCK, THE MaChIAVELlian MOMENT: FloRENTINE POlitiCAL THOUGHT AND THE ATLANTIC REPUBLICAN TRADITION (1975); WOOD, supra note 50; GORDON S. WOOD, THE CREATION OF THE AMERICAN REPUBLIC, 1776-1787 (1969); see also Williams, The Terrify- 
this history is textual. They read the Amendment's description of a right "to keep and bear Arms" as obviously and necessarily conveying an intention to protect individual gun ownership whether or not such ownership is related to militia service. ${ }^{111}$

One problem with this reading is that it ignores the first half of the Amendment. Read as a whole — "A well regulated Militia, being necessary to the security of a free State, the right of the people to keep and bear Arms, shall not be infringed" - the Amendment straightforwardly declares its aim to preserve the "well regulated Militia" that are "necessary to the security of a free State." The revisionists seek to

ing Second Amendment, supra note 3 (describing the Second Amendment as rooted in republican political theory). Only since this republicanism has waned have Americans committed themselves to the sort of "individual right" imagined by the Libertarian Approach.

111. Some revisionists buttress this textual argument with a historical argument to the effect that the Second Amendment incorporated an English tradition of protecting arms ownership by individuals, dating at least to the 1689 English Bill of Rights. See generally MALCOLM, supra note 3; see also Emerson, 46 F. Supp.2d at 602 . Undoubtedly the English Bill of Rights was an important precedent for the Founders - but rather than supporting the Libertarian Approach, this precedent argues in favor of a militia-focused interpretation of the Second Amendment. Defending that claim in full would require too long a detour from my central argument in this Article, but here is the defense in a nutshell: The English Bill of Rights resulted from a 60-year struggle for power between the largely Protestant Parliament and a succession of Stuart kings allied with Catholic interests. See generally BARRY Coward, The Stuart Age: A History of ENGland 1603-1714 (1980); LAwrenCE Stone, The Causes of THE English Revolution, 1529-1642 (1972). Parliament finally won the conflict, installing a Protestant king and adopting a Bill of Rights containing the following:

Whereas the late King James II ... did endeavor to subvert and extirpate the Protestant religion and the laws and liberties of this kingdom ... by raising and keeping a standing army within this kingdom in time of peace without consent of parliament and ... by causing several good subjects being Protestants to be disarmed at the same time when papists were both armed and employed contrary to law,... [we] declare ... that the raising or keeping a standing army within the kingdom in time of peace, unless it be with consent of parliament, is against law; that the subjects which are Protestants may have arms for their defense suitable to their conditions and as allowed by law ....

SOURCES OF ENGlish CONSTITUTIONAL History 600-01 (Carl Stephenson \& Frederick George Marcham eds. and trans., 1937). These provisions were designed to ensure a feudal militia in which each lord commanded men-in-arms from the areas under his dominion. The Stuart kings had wanted a centralized militia with officers appointed by the king. Compare id. at 486 (reprinting The Militia Ordinance of 1642) with id. at 541 (reprinting Militia Act of 1661). Thus the guarantee was limited to Protestants, and it applied only to arms "suitable to their conditions" (meaning status in the feudal hierarchy). It explicitly recognized the numerous common law and statutory restrictions on gun possession which existed both before and after adoption of the English Bill of Rights. See Bellesiles, Gun Laws, supra note 3, at 571-73. The purpose of the English Bill of Rights was not to protect individual British citizens' rights to own weapons but to guarantee that Parliament's noblemen would be able to field armed forces independent of the crown - a concern directly analogous to that of the American Anti-Federalists who sought to prevent the new central government from monopolizing military force.

As an alternative to relying on British history, some revisionists have recently argued for the Libertarian Approach on Fourteenth Amendment grounds. See AMAR, supra note 9; STEPHEN P. HALBROOK, FREEDMEN, THE FOURTEENTH AMENDMENT, AND THE RIGHT TO BEAR ARMS, 1866-1876 (1998). I consider this argument infra Section IV.A. 
avoid this straightforward reading by decoupling the Amendment's two halves. They call the first half ("A well regulated Militia, being necessary to the security of a free State") a "justification clause" 112 or a "prefatory phrase"113 or a "cautionary note," 114 and they insist that the second half ("the right of the people to keep and bear Arms, shall not be infringed") provides the force of the Amendment and must be read independently.

Eugene Volokh has recently provided a rationale for this interpretive move, demonstrating that it was "commonplace" for state constitutional drafters in the late 18th Century to preface rights-granting provisions with "purpose clauses," and that these purpose clauses were not read strictly to limit the right at issue. ${ }^{115}$ At most, however, Volokh's work shows that the scope of a constitutional provision is not necessarily limited by its "purpose clause" - he provides no excuse for ignoring the Second Amendment's purpose clause altogether, as the revisionists' Libertarian Approach does. ${ }^{116}$

More important, splitting the Amendment in two is simply artificial, because both halves of the Amendment - the "bear Arms" language as well as the "well regulated Militia" language - reflect the Founders' purpose of protecting the militia. The revisionists read the phrase "bear Arms" as equivalent to "carry guns" - but to the Amendment's framers, the phrase "bear Arms" itself denoted the military possession of weapons. While the revisionist's reading of the "plain text" of the Amendment may at first glance seem appealing,

112. Volokh, supra note 3, at 796.

113. Lund, supra note 3 , at 21.

114. Reynolds, supra note 3 , at 467.

115. Volokh, supra note 3 .

116. In addition to the ordinary principle against rendering any constitutional text "mere surplusage," Marbury v. Madison, 5 U.S. 137, 174 (1803), a close look at the grammar of the Second Amendment suggests that the Founders intended the Amendment to be read as a unitary whole. Note that the drafters inserted two unusual commas in the Amendment; under ordinary usage, the first and third commas are unnecessary. If these commas had not been inserted, it might be possible to understand the first half of the Amendment as simply explaining the rationale for the second half (the Amendment would then read: "A well regulated Militia being necessary to the security of a free State, the right of the people to keep and bear Arms shall not be infringed."). Instead, the first unusual comma - between "Militia" and "being" - forces the reader to search for a verb for which "Militia" is the subject. That verb does not appear until "shall not be infringed" near the end of the Amendment. The second unusual comma - between "Arms" and "shall" - sets off the verb phrase "shall not be infringed" from the preceding language; it suggests that the subject for this verb phrase is not simply "the right of the people to keep and bear Arms." The grammatical effect of these two unusual commas is to link "A well regulated Militia" to "shall not be infringed" - to emphasize, in other words, that the goal of the Amendment is to protect the militia against federal interference. I do not place enormous weight on this argument, but considering that the use of punctuation in the Constitution generally conforms to modern conventions, and that the Second Amendment was redrafted at least twice during the First Congress, I do believe the Amendment's curious punctuation supports a militia-focused reading. 
that is only because the ordinary meaning of the phrase "bear Arms" has changed over time.

The clearest evidence of the framers' understanding of the language is in the original draft of the Amendment proposed in the First Congress by James Madison: "The right of the people to keep and bear arms shall not be infringed; a well armed, and well regulated militia being the best security of a free country: but no person religiously scrupulous of bearing arms, shall be compelled to render military service in person [emphasis added]." 117 In the last clause of this version (the conscientious objector provision), Madison clearly used the phrase "bearing arms" to refer solely to the possession of weapons for military use. There is no reason to think that virtually the same phrase - "bear arms" - should have a different, much broader meaning elsewhere in the very same sentence.

Madison's use of the phrase "bear arms" to refer to military activities is echoed in other contemporary usages. Thus the Declaration of Independence charged King George with forcing captive Americans to "bear arms against their country." 118 Searching a Library of Congress database containing all official records of debates in the Continental and U.S. Congresses between 1774 and 1821 reveals thirty uses of the phrase "bear arms" or "bearing arms" (other than in discussing the proposed Second Amendment); in every single one of these uses, the phrase has an unambiguously military meaning. ${ }^{119}$ The Continental Congress, for example, approved a prisoner exchange with the British conditioned on the returned prisoners being forbidden to "bear arms" for a specified period, ${ }^{120}$ and the Twelfth Congress debated legislation concerning prisoners taken "whilst voluntarily bearing arms in the service of Great Britain."

117. DoCumENTARY ReCORD, supra note 78 , at 12. See also 6 SourCES AND DOCUMENTS OF UNITED STATES CONSTITUTIONS 345 (William F. Swindler ed., 1976) (reprinting New Hampshire Constitution of 1784: "No person who is conscientiously scrupulous about the lawfulness of bearing arms, shall be compelled thereto, provided he will pay on equivalent."); 1 ELLIOT'S DEBATES, supra note 47, at 335 (reprinting constitutional amendment proposed by Rhode Island's 1790 ratifying convention: "That the people have a right to keep and bear arms; ... That any person religiously scrupulous of bearing arms ought to be exempted upon payment of an equivalent to employ another to bear arms in his stead.").

118. 1 ELLIOT'S DEBATES, supra note 47, at 62.

119. A Century of LAWMaking fOr a NEW NATION: U.S. Congressional DOCUMENTS AND DEBATES, available at http://memory.loc.gov/ammen/amlaw/lawhome. $\mathrm{html}$ [hereinafter CENTURY OF LAWMAKING]. I didn't choose the dates to search - that is what was available at the time of writing.

120. Journal of THE CONTINENTAL CONGREss, 1774-1789, at 1030 (Tues., Nov. 7, 1780) (Worthington C. Ford et al. eds., 1904-1937), available at CENTURY OF LAWMAKING, supra note 119.

121. JOURNAL OF THE SENATE OF THE UNITED STATES OF AMERICA, 1789-1873, at 264 (n.p, n.d.), available at CENTURY OF LAWMAKING, supra note 119. 
These usages were standard at the time the Second Amendment was adopted. The Oxford English Dictionary defines "to bear arms" as meaning "to serve as a soldier, do military service, fight." 122 It defines "to bear arms against" as meaning "to be engaged in hostilities with." 123 As an exemplary use of the phrase in 1769 , the $O E D$ gives "An ample ... pardon to all who had born arms against him," and the exemplary use from 1609 is: "He bure armes, and made weir against the king." ${ }^{24}$ The most persuasive account of the etymology of the phrase "bear arms" remains that of Garry Wills, who elegantly concludes: "To bear arms is such a synonym for waging war that Shakespeare can call a just war 'just-borne arms' and a civil war 'selfborne arms'." 125

Indeed, the word "arms" itself has a primarily military connotation. According to the $O E D$, the oldest established meaning of "arms" (other than as the plural of "arm," meaning limb) is "armour, mail." 126 The next oldest meaning is "[i]nstruments of offence used in war; weapons." 127 The $O E D$ quotes a 1794 dictionary: "By arms, we understand those instruments of offence generally made use of in war; such as firearms, swords, etc. By weapons, we more particularly mean instruments of other kinds (exclusive of fire-arms), made use of as offensive on special occasions." ${ }^{128}$ Accordingly, nineteenth-century judges had no trouble understanding that "the phrase 'bear arms' ... has a military sense, and no other .... A man in the pursuit of deer, elk and buffaloes, might carry his rifle every day, for forty years, and, yet, it would never be said of him, that he had borne arms ...."129

122. 1 OXFORD ENGLISH DiCTIONARY 634 (J.A. Simpson \& E.S.C. Weiner eds., $2 d$ ed. 1989).

123. 2 id. at 21.

124. $I d$. (alteration in original).

125. Garry Wills To Keep and Bear Arms, N.Y. REV. BooKs, Sept. 21, 1995 (tracing etymology of phrase bear arms and concluding that dominant meaning is military); see also GARRY WILLS, A NECESSARY EVIL 252-60 (2000) (same).

126. 1 OXFORD ENGLISH DICTIONARY, supra note 122 , at 633-34.

127. Id. at 634 .

128. Id.

129. Aymette v. State, 21 Tenn. (2 Hum.) 154, 161 (1840) (interpreting Tennessee Constitution); see also Ex parte Rameriz, 226 P. 914, 921 (Cal. 1924) ("An examination of the numerous authorities in various states will show that the right to keep and bear arms as guaranteed by a state constitutional provision similar to the federal amendment refers only to the bearing of arms by the citizens in defense of a common cause."); Hill v. State, $53 \mathrm{Ga}$. 473,474 (1874) ("The language of the constitution of this state, as well as that of the United States, guarantees only the right to keep and bear the 'arms' necessary for a militiaman."); City of Salina v. Blaksly, 72 Kan. 230, 232 (1905) (Both U.S. and Kansas Constitutions "appl[y] only to the right to bear arms as a member of the state militia, or some other military organization provided by law."); Ex parte Thomas, 21 Okla. 770 (1908) (interpreting Oklahoma Constitution) ("As the object for which the right to keep and bear arms is secured is of general and public nature, to be exercised by the people in a body, for their common defense, so the arms, the right to keep which is secured, are such as are usually em- 
Now, I do not mean to say there are no examples at all of Founding-era uses of the phrase "bear arms" in a non-military sense. There are such examples, and the revisionists make the most of them. ${ }^{130} \mathrm{~A}$ full review of the evidence, however, shows that at the time

ployed in civilized warfare.") (quoting Aymette, 21 Tenn. at 158); English v. State, 35 Tex. 473,476 (1872) ("The word 'arms' in the connection we find it in the Constitution of the United States refers to the arms of a militiaman or soldier, and the word is used in its military sense."); State v. Workman, 14 S.E. 9, 11 (W. Va. 1891) ("[I]n regard to the kind of arms referred to in the [Second A]mendment, it must be held to refer to weapons of warfare to be used by the militia."); $c f$. JOEL PRENTISS BISHOP, COMMENTARIES ON THE LAW OF STATUTORY CRIMES $\$ 792$, at 497 (1873) (Second Amendment "protects only the right to 'keep' such 'arms' as are used for purposes of war ... since such, only, are properly known by the name of 'arms;' and such, only, are adapted to promote 'the security of a free State.' In like manner, the right to 'bear' arms refers merely to the military way of using them...."); Lucilius A. Emery, The Constitutional Right to Keep and Bear Arms, 28 HARV. L. REV. 473, 476 (1915) ("The single individual or the unorganized crowd, in carrying weapons, is not spoken of or thought of as 'bearing arms.' ").

The presence of the word "keep" in the Second Amendment does not change the Amendment's fundamentally military meaning. The consistent use of the phrase "keep and bear arms" by the Founders and their forebears suggests that it should be understood as a single term of art, such as "arbitrary and capricious" or "willful, deliberate and premeditated." If we feel the need to give "keep" an independent meaning in the Amendment, we can do so by reading it simply preclude a narrow interpretation of the Amendment that would protect only the possession of firearms by persons actively engaged in militia duties (permitting, for example, the federal government to require weapons to be stored in a central depository). The Founders were in fact concerned about such a possibility, as they had seen the British seek to require Massachusetts militiamen to bring their weapons to an armory - where they would have been easily controlled by British troops. By protecting the right to "keep" as well as "bear" arms, the Founders may have seen the Amendment as ensuring that militiamen would be able to store their weapons at home, thus making militia disarmament more difficult.

130. The example relied upon most heavily by the revisionists is the "Pennsylvania Minority Report," a dissenting statement issued by Pennsylvania Anti-Federalists after losing the ratification vote in their state convention. See 3 THE COMPLETE ANTI-FEDERALIST, supra note 49, at 145 (reprinting "The Address and Reasons of Dissent of the Minority of the Convention of Pennsylvania To Their Constituents"); see also, e.g., Kates, Original Meaning, supra note 3, at 222 (citing Pennsylvania Minority Report); David B. Kopel, The Second Amendment in the Nineteenth Century, 1998 BYU L. REV. 1359, 1406-07 (same); Lund, supra note 3, at 60-61 (same). This document contained a series of proposed amendments to the new Constitution, including this:

That the people have a right to bear arms for the defence of themselves and their own state, or the United States, or for the purpose of killing game; and no law shall be passed for disarming the people or any of them, unless for crimes committed, or real danger of public injury from individuals; and as standing armies in the time of peace are dangerous to liberty, they ought not to be kept up: and that the military shall be kept under strict subordination to and be governed by the civil powers.

3 ThE COMPLETE ANTI-FEDERALIST, supra note 49, at 151 . On the one hand, this text certainly shows a Founding-era use of "bear arms" that, consistent with the Libertarian Approach, includes both military and non-military meanings. On the other hand, the Pennsylvania Minority's proposed right to bear arms "for the purpose of killing game" is unlike every state constitution of its time and every other state proposal for amending the federal Constitution - and most important, it was rejected by the drafters of the Second Amendment. Indeed, the differences between the Pennsylvania proposal and the Second Amendment argue strongly against the Libertarian Approach. In the first place, the fact that the Pennsylvania Minority felt the need to specify the reach of their proposal suggests that "killing game" would not otherwise have been considered material to the right to bear arms. Second, the Pennsylvania proposal would have prohibited disarming either "the people" or 
the Second Amendment was adopted, the overwhelmingly dominant meaning of the phrase "bear arms", particularly in a political context, was to refer to the use of weapons by soldiers or militiamen. At the very least, the extensive evidence for a military reading of "bear Arms" means that the Libertarian Approach is not compelled simply by the Founders' use of that phrase. And once the "plain text" argument is gone, the game is up for the Libertarian Approach. For even if the textual evidence were equivocal, with the military and nonmilitary readings of "bear Arms" both being equally plausible (and again, the evidence for a military reading is far stronger), the Second Amendment's "purpose clause" and the legislative history detailed in Part I would make the Libertarian Approach indefensible. The goal of those who framed the Second Amendment was to protect a federalist (lowercase " $\mathrm{f}$ " - the opposite of "national") military structure, in which the militia occupied a central position.

\section{The Revisionists' Best Shot: The "Unorganized Militia Approach"}

But the revisionists' repertoire is not limited to the implausible Libertarian Approach. They also propose another justification for a broad right of firearm ownership. This strand of the revisionist argument accepts that the purpose of the Second Amendment was to protect the states' ability to maintain organized militia, but holds that in order for states to have this ability, they must have available an armed populace (or as the revisionists prefer, an "unorganized militia"). Accordingly, in this view, any (federal) law that (materially) denies the states access to an armed populace violates the Second Amendment (or at least burdens a protected constitutional interest - leave aside for the moment what sorts of government interests might justify such burdening). ${ }^{131}$ I will call this the "Unorganized Militia Approach."

\footnotetext{
"any of them"; by contrast, the Second Amendment speaks only of "the people" in their collective capacity as militiamen.

Moreover, historian Saul Cornell argues that the Pennsylvanians themselves had a considerably more complex understanding of the right to bear arms than the libertarian reading of the Minority Report would suggest. See Cornell, supra note 3, at 227-30. In 1776, Pennsylvania adopted a state constitution providing that "people have a right to bear arms for the defense of themselves and the State." Id. at 228. The following year, the state legislature enacted legislation known as the Test Acts which limited that right only to those citizens who took a loyalty oath, which "as much as forty percent of the citizenry" refused to do. Id. Even for Pennsylvanians, then, "[g]un ownership was based on the idea that one agreed to support the state and to defend it against those who might use arms against it." Id. at 229.
}

131. The parentheticals are intended to suggest that, were courts to adopt the revisionists' Unorganized Militia Approach, many crucial and difficult issues would remain to be fleshed out - which is not to say, of course, that courts will always recognize this task and attempt to tackle it. In Emerson, for example, the Court leapt from its determination that Timothy Emerson's desire to possess a weapon was a cognizable Second Amendment interest to its conclusion that the statute at issue was unconstitutional, without pausing to consider whether the government's interest in preventing domestic violence justified the statute. See United States v. Emerson, 46 F. Supp. 2d 598 (N.D. Tex. 1999). 
While the Second Amendment right envisioned by the Unorganized Militia Approach may not be so broad as that envisioned by the Libertarian Approach, the Unorganized Militia Approach is still "revisionist" because it contrasts sharply with the approach dominant in modern Second Amendment cases. The courts' approach - call it the "Organized Militia Approach" - sees the purpose of the Second Amendment as "protect[ing] only the possession or use of weapons that is reasonably related to a militia actively maintained and trained by the states." ${ }^{133}$ The effect of the courts' approach is to limit the Second Amendment to preventing federal interference with state $\mathrm{Na}$ tional Guard units. ${ }^{134}$

These two approaches - the revisionists' Unorganized Militia Approach and the courts' Organized Militia Approach - certainly have very different consequences for gun control legislation. Consider, for example, the federal statutes banning machine guns ${ }^{135}$ and militarystyle "assault weapons." "136 These laws certainly interfere with states' access to a populace armed for military service, and would presumably be unconstitutional under the revisionists' Unorganized Militia Approach. ${ }^{137}$ Because these statutes permit possession of the regulated

132. While the revisionists' rhetoric often sounds like it is supporting a Libertarian Approach, many revisionists carefully avoid this pitfall and adopt the Unorganized Militia Approach. See, e.g., Reynolds, supra note 3; Van Alstyne, supra note 3.

133. See United States v. Wright, 117 F.3d 1265, 1273 (11th Cir. 1997) (emphasis added); see also cases cited supra note 2. While I refer to the Organized Militia Approach as the "courts' approach," it should be noted that modern Second Amendment doctrine has been elaborated largely by the federal Courts of Appeal; the Supreme Court has said very little about the Amendment. See David Yassky, The Sound of Silence: The Supreme Court and the Second Amendment, 18 ST. LOUIS U. PUB. L. REV. 189 (1999); see also infra Section IV.C.

134. The National Guard is a set of reserve military forces attached to both the federal government and the states. The basic structure of the modern National Guard was established by the Dick Act of 1903, ch. 196, Stat. 775 (1903). This statute provided federal funding and training for states' militia units; units funded and trained under the Act were denominated the "National Guard" and defined as the "organized militia." Statutes subsequent to the Dick Act have placed the National Guard under ever-greater federal control. Currently, anyone enlisting in a National Guard unit is automatically also enlisted into a "reserve" unit of the U.S. Army (or Air Force), the federal government may use National Guard units for a variety of purposes, and the federal government appoints the commanding officers for these units. See 10 U.S.C. $\S 12301$ (1994) (federal authority to transfer Guard members to "active duty"); $i d$. at $\$ \S 12201-12215$ (command structure of National Guard); Perpich v. Dep't of Def., 496 U.S. 334, 345-46 (1989) (describing "dual enlistment" system). The federal government also provides "virtually all of the funding" for the National Guard. Perpich, 496 U.S. at 351. Today, each state has a branch of the National Guard, with a total strength of approximately 450,000 members. See Bob Haskell, Educating Executives, ON GUARD (April 2000), available at http://ngb.dtic.mil/news_center/onguard/2000/april/ executives.html. No state maintains any other organized militia. See generally MAHON, supra note 32 (describing the exclusive role of the National Guard today).

135. 26 U.S.C. $\$ \S 5801-5872$ (1994). The statute does permit private possession of machine guns under certain limited circumstances; the effect, however, is a near-total ban.

136. 18 U.S.C. $\$ 922(v)$, app. A (1994).

137. Maybe not though - no right is absolute, and the revisionists typically avoid giving examples of actual statutes that they contend are unconstitutional. 
weapons by National Guard members,${ }^{138}$ however, they are acceptable under the Organized Militia Approach - and courts have uniformly upheld them. In several cases, defendants convicted of machine gun possession have specifically argued that under the Second Amendment their membership in an "unorganized militia"139 (or a "sedentary militia," 140 an "organized private militia,"141 or the "Posse Comitatus, a militia-type organization"142) entitles them to possess military weapons. Courts have consistently rejected these arguments. ${ }^{143}$ Courts' rejection of the Unorganized Militia Approach is all the more striking considering that many states have on their books statutes expressly recognizing an "unorganized militia," typically consisting of all "ablebodied male citizens" within a specified age range. ${ }^{144}$ Even when courts are made aware of these laws, they have insisted that the Second Amendment protects gun possession only when related to "the actual, as opposed to potential, organization, training and equipping of the unorganized militia." 145

The Unorganized Militia Approach, then, is clearly at odds with Second Amendment case law. But unlike the Libertarian Approach, this strand of revisionism does have considerable support in the Second Amendment's text and legislative history. While the revisionists' reading of "bear Arms" in the Amendment may be anachronistic, their reading of "Militia" is more solidly grounded; the text of the Amendment does identify the "Militia" (used in the first half of the Amendment) with "the People ... bear[ing] Arms" (in the second half). As we have seen, in practice Founding-era militias were far from universal, but in the Founders' conceptual framework the militia consisted of the mass of ordinary citizens, trained to arms and available to serve at the call of the state. As George Mason put it: "Who are the militia? They consist now of the whole people, except [for] a few pub-

138. 26 U.S.C. $\S 5844(1), 5853$.

139. Wright, 117 F.3d at 1272.

140. United States v. Warin, 530 F.2d 103, 106 (6th Cir. 1976).

141. United States v. Kuehnoel, No. 97-30189, 1999 U.S. App. LEXIS 16373, at *6 (9th Cir. July 12, 1999).

142. United States v. Oakes, 564 F.2d 384, 387 (10th Cir. 1977).

143. Kuehnoel, 1999 U.S. App. LEXIS 16373; United States v. Rybar, 103 F.3d 273 (3d Cir. 1996), cert. denied, 522 U.S. 807 (1997); United States v. Hale, 978 F.2d 1016 (8th Cir. 1992); Oakes, 564 F.2d at 387; Warin, 530 F.2d at 103.

144. See, e.g., GA. CODE ANN. § 38-2-3(d) (1995) (defining state's "unorganized militia" as "all able-bodied male residents of the state between the ages of seventeen and forty-five [with certain exceptions]"); KAN. CONST. art. VIII, § 1 (defining state's militia as "all ablebodied male citizens between the ages of twenty-one and forty-five [with certain exceptions]").

145. See United States v. Wright, 117 F.3d 1265,1274 (11 ${ }^{\text {th }}$ Cir. 1997); see also Oakes, 564 F.2d at 387 (refusing to find Second Amendment violation "merely because [the defendant] is technically a member of the Kansas militia"). 
lic officers." 146 When the Second Congress sought to exercise its constitutional authority to "provide for organizing, arming and disciplining the Militia," it directed "each and every free able-bodied white male citizen of the respective states [except for persons exempted under state law and certain other exempted classes] ... who is ... of the age of eighteen years, and under the age of forty-five years" to enroll in the militia of their states. ${ }^{147}$ Or as Patrick Henry declared at the Virginia ratifying convention: "The great object is, that every man be armed."148

Today's National Guard is thus a far cry from what the Founders' understood a militia to be. ${ }^{149}$ Indeed, the Founders' did have a concept that approximates today's National Guard - but it was a concept they disapproved. This is the "select militia" - a specially trained part of the citizenry. To the Founders, a select militia was little better than an army. The Philadelphia Convention explicitly rejected a proposal to create a "select militia" for the federal government, ${ }^{150}$ as did the Third Congress. ${ }^{151}$ The Constitution's proponents, moreover, repeatedly denied Anti-Federalist charges that Congress' power to "provide for training" the militia would lead to creation of a select militia. ${ }^{152}$ Imagine, then, that in 1792 the Second Congress had enacted a statute prohibiting possession of the most commonly used military weapon of the day, except among members of the army and a small "select militia" - a statute roughly analogous to the machine gun ban of today. It is hard to believe that even the most nationalist of the Federalists would have thought such a statute consistent with the Second Amendment. ${ }^{153}$

146. 3 ELLIOT'S DEBATES, supra note 47 , at 425 .

147. Act of May 8, 1792, ch. 23, 1 Stat. 271, 271. The Act did exempt federal officials from militia service, along with customhouse officers, post officers and stage drivers, ferrymen, pilots, mariners, and any persons exempted by the laws of the respective states.

148. 3 ELLIOT'S DEBATES, supra note 47 , at 386 . I use this quotation advisedly. Henry was among the most determined and impassioned Anti-Federalist opponents of the Constitution, and this quotation is in fact from a speech arguing against ratification. As Henry's intentions for the new nation were plainly not shared by those who framed and ratified the Constitution, I want to avoid the trap of relying on him as a reliable indicator of the Founders' world-view. That is precisely the trap fallen into by some revisionists, who build their entire arguments around quotations from Anti-Federalists. See, e.g., HALBROOK, supra note 3 . On the specific issue of the composition of the militia, however, Henry's views are exemplary.

149. I briefly describe the National Guard at supra note 134 .

150. See 2 FARRAND, supra note 48 , at 330-33.

151. See Leon Friedman, Conscription and the Constitution, $67 \mathrm{MICH}$. L. REV. 1493, 1537-38 (1969).

152. See 3 ELLIOTT'S DEBATES, supra note 47, at 425-26 (statement of George Mason).

153. Of course, the actual response of a Federalist to such a proposal would have been that Congress lacked power to enact such a ban under Article I, Section 8. In Federalist No. 84, Alexander Hamilton famously argued that the enumeration of powers obviated a bill of rights - that the Constitution gave the federal government no power to regulate, for exam- 


\section{D. "Translating" the Second Amendment}

It does not necessarily follow, however, that a judge today should find a machine gun ban inconsistent with the Second Amendment. As Lawrence Lessig reminds us, remaining faithful to the Founders' intent sometimes requires judges to modify the application of constitutional text over time. ${ }^{154}$ Lessig uses the metaphor of "translation" to describe this process. Just as a literal translation of a foreign text can actually distort its original meaning, so too can a literal application of constitutional text subvert the Founders' intent; just as a translator's creation of a new text can be an act of fidelity, so too can a judge act faithfully in expressing Founding ideals through new doctrine - even new doctrine that is directly at odds with old doctrine. In Lessig's formulation, "translation" is appropriate, even necessary, whenever constitutional "presuppositions" - which he defines as contextual facts upon which the phrasing of the document was contingent - change. ${ }^{155}$

Perhaps it is possible, then, to justify modern courts' narrow reading of the Second Amendment as an instance of valid translation. ${ }^{156}$ While the courts themselves have not framed their analysis in this way - unsurprisingly, courts have presented modern doctrine as a straightforward implementation of the Founders' intent - at least two scholars, Dennis Henigan and Keith Ehrman, have attempted a Lessig-like defense of the courts. ${ }^{157}$ This defense begins with the ob-

ple, speech or worship. THE FEDERALIST NO. 84 (Hamilton). The same argument would presumably apply to firearm ownership.

154. See Lessig, Fidelity as Translation, supra note 26; Lessig, Fidelity in Translation, supra note 26; Lessig, Understanding Changed Readings, supra note 26.

155. Or in Lessig's words: presuppositions are those elements of a context "relied upon by the author ... in just the sense that had they been other than they were when the author first used these words, then the author would have used words other than she did." Lessig, Fidelity in Translation, supra note 26, at 1179-80. And: "If between two contexts a presupposition has changed... [then] the reader must accommodate for this changed presupposition if she is to be faithful to the text's original meaning." Id. at 1180-81.

156. Lessig himself cites the Second Amendment as a possible candidate for translation - although he appears to believe that translating the Amendment would yield a result similar to the revisionists' Unorganized Militia Approach, rather than supporting the courts. See id. at 1204-05. The few lines he devotes to the Amendment, however, are more in the nature of a tentative suggestion than a full-blown argument.

157. See Henigan, supra note 3; Ehrman \& Henigan, supra note 3 . Henigan and Ehrman neither use Lessig's terminology nor rely upon his work; nonetheless, I think their argument is a good example of what Lessig has in mind by "translation."

More recently, Richard Uviller and William Merkel have argued, at length and with great sophistication, that developments in military structure since the Founding have drained the Second Amendment of much if not all of its original force. See Uviller \& Merkel, supra note 3 . While I received a copy of their article too late to include discussion of it in the text above, I believe my analysis of the Henigan-Ehrman argument applies also to that of Uviller and Merkel.

The other leading scholars who have criticized the revisionists are David Williams and Carl Bogus. See Bogus, The Hidden History of the Second Amendment, supra note 3; Bogus, Race, Riots, and Guns, supra note 3; Williams, Conjuring with the People, supra note 3; 
servation that the nature and structure of the American militia have changed radically since the Founders' day. Henigan and Ehrman summarize the "key developments in the history of the militia" as "the split between an organized and unorganized militia; the passage of the militias from state authority to largely federal authority; and the rise of the army as the main defense force in the country."158

The end result of these changes is the disappearance of anything the Founders would have recognized as a militia. Today we have the National Guard (which, as the revisionists correctly observe, the Founders would have seen as little better than a standing army), and we have self-proclaimed "citizen militias" constituted wholly independently of any government - and mostly, of course, we have the vast bulk of citizens who have no involvement whatever with any form of military organization. ${ }^{159}$

These developments certainly constitute a change in "presupposition" as Lessig uses the term. To the Founders, protecting gun ownership by "the people" amounted to more or less the same thing as protecting gun ownership by the "Militia." Now the two are quite different.

Henigan and Ehrman argue that this change justifies a translation. They correctly perceive that modern interpreters of the Amendment are presented with a choice that did not exist in 1791 - a choice between protecting "the people" and protecting the "Militia." Their claim, in essence, is that the latter alternative is more consistent with the Founders' intentions - that if the Founders had anticipated the developments of the following two centuries, they would have made clear their desire only to protect the "Militia."

This argument is stronger than it may first appear. As David Williams has convincingly shown, the ideology underlying the Second Amendment was deeply republican - to an extent that is easy to miss because modern Americans simply don't share many of the Founders' republican assumptions and beliefs. ${ }^{160}$ The average citizen whom the Founders wished to see armed was a man of republican virtue - a

Williams, The Terrifying Second Amendment, supra note 3. Like Henigan-Ehrman and Uviller-Merkel, Williams believes that changed circumstances since the Founding require a "translation" of the Amendment; unlike them, however, he does not think the courts' approach is adequate. Bogus' main tack is not to propose a translation, but rather to dispute the revisionists' history.

158. Ehrman \& Henigan, supra note 3, at 39. These developments, and the entire history of the militia, are described well in MAHON, supra note 32.

159. The transformation can be dated to the 1903 Dick Act. See supra note 134. My argument in the next Part will be that a statute like the Dick Act was possible only after the Civil War.

160. Williams, Conjuring with the People, supra note 3; Williams, The Terrifying Second Amendment, supra note 3; see also Bailyn, supra note 110; Pocock, supra note 110; Wood, supra note 110 . 
man shaped by his myriad ties to his community, the most important for this purpose being the militia. As Williams puts it: "The militia was a precondition for the right to arms. Without a militia the right is meaningless." 161 Thus "the people" spoken of in the Amendment were not simply all citizens (or even all adult males); rather, "the people" were assured access to arms in their role as a "well regulated Militia."

This role, moreover, was created and defined by the state. A group of men did not become a "militia" until they were organized by the state to serve the common defense. ${ }^{162}$ John Adams expressed the distinction between arms-bearer-as-individual and arms-bearer-asmilitiaman:

To suppose arms in the hands of citizens, to be used at individual discretion, except in private self-defense, or by partial orders of towns, counties or districts of a state, is to demolish every constitution, and lay the laws prostrate, so that liberty can be enjoyed by no man; it is a dissolution of the government. The fundamental law of the militia is, that it be created, directed, and commanded by the laws, and ever for the support of the laws. ${ }^{163}$

This understanding of the militia was written into the Constitution, which specifically granted to states the authority to "Appoint[] ... the Officers" of their militia; individual citizens could not deem themselves militiamen. ${ }^{164}$ The text of the Second Amendment itself disallows any equation between the militia and all American citizens in their individual capacities. The Amendment does not use the simple word "Militia," but the phrase "well regulated Militia."

The ideology of the militia expressed by John Adams was also borne out by the Founders' practice. In 1787, four states sent their militia to quell Shays' Rebellion in Massachusetts. The framers of the Second Amendment did not see Daniel Shays and his followers as "militia" - they were insurrectionaries pursuing a private interest (debt relief) and had no claim to public protection. ${ }^{165}$ Similarly, seven

161. Williams, The Terrifying Second Amendment, supra note 3, at 555.

162. See 4 ElLIOT'S DEBATES, supra note 47 , at 424 ("If we are, then, to govern the militia, it must be such men as the particular states have declared to be militia.") (statement of Rep. Williamson), see also Marguerite Driessen, Private Organizations and the Militia Status, 1998 BYU L. REV. 1, 7 ("[L]egitimate militias were organized by the State. Being a member of a militia was not something an individual conferred upon himself.").

163. John Adams, Defense of the Constitutions of Government of the United States, in 6 WORKS OF JOHN ADAMS 3, 197 (Charles F. Adams ed., 1851).

164. U.S. CONST. art. I, $\S 8$, cl. 16.

165. See generally DAVID P. SZATMARY, SHAYS REBELLION (1980). Thomas Jefferson is the exception that proves the rule. In a letter to William Smith (the letter containing the famous quotation "The tree of liberty must be refreshed from time to time with the blood of patriots and tyrants. It is its natural manure."), Jefferson criticized the Philadelphia delegates ("Our Convention has been too much impressed by the insurrection in Massachusetts") and praised Shays' rebels ("[C]an history produce an instance of rebellion so honorably conducted?"). See Alpheus Thomas Mason, ed., FREE GOVERNMENT IN THE 
years later the Whiskey Rebellion was attacked by both leading Federalists and former Anti-Federalists. ${ }^{166}$ No one in 1794 would have suggested that rebellious Pennsylvania farmers were a "militia" protected by the Second Amendment; there is no evidence that even the rebels themselves invoked the Second Amendment. ${ }^{167}$

As these episodes make clear, those who framed and ratified the Second Amendment were seeking not to enshrine some generalized right of Americans to revolt against government, nor to empower individuals or small groups of disaffected citizens to take up arms against the established order. Rather, they sought to protect a specific set of institutions - organized, state-based militia - that they saw as playing a crucial, liberty-protecting role in their new government structure. Outside of the National Guard, these institutions no longer exist.

At the core of Henigan and Ehrman's (and the courts) position, then, is an important and correct insight: Given the disappearance of a universal-service citizen-militia, simply mimicking the Founders' Second Amendment doctrine (or, more precisely, mimicking the doctrine Founding-era courts would have developed if necessary) no longer serves the Founders' purposes. Today, recognizing a broad constitutional right to gun ownership cannot plausibly be seen as empowering the states to resist aggression by the national government, or as ensuring a decentralized alternative to a national standing army. Moreover, considering the Founders' republican assumptions, widespread arms ownership would have looked very different to the Founders had militia service not been equally widespread - more like arming the mob than like arming "the people." Thus the revisionists' Unorganized Militia Approach is, at best, an imperfect "translation" of the Founders' intent.

So far, so good for Henigan and Ehrman. The problem is, however, that proving the revisionists wrong doesn't mean the courts are right. If the revisionists lose a good deal in their translation of the Second Amendment, the courts' approach — translating both "Militia" and "the people" as "the National Guard" - loses even more. After all, what modern Second Amendment doctrine really represents is not an effort to implement the Founders' world-view but a capitulation to the complete obsolescence of that world-view. The Founders' effort to craft a division of military power between the national army and the states' militia has failed utterly — but that does not justify pretending that such a division was not the Founders' purpose. Truly remaining

MAKING 247 (2d ed. 1956) (reprinting letter dated Nov. 13, 1787, from Thomas Jefferson to William Smith).

166. See SLAUGHTER, supra note 86, at 190-204; Saul Cornell, supra note 3.

167. Bellesiles, Suicide Pact, supra note 3, at 256. 
faithful to that purpose would require neither a scaling back of the Second Amendment so that it protects only the National Guard, nor an extension of it to protect private gun ownership, but rather a frontal assault on the agglomeration of national military power that the Founders were determined to prevent.

The example of the Second Amendment thus reveals a significant weakness in the notion of interpretation-as-translation: What happens when a change in a "presupposition" necessarily involves repudiation of one of the Founders' core value judgments? ${ }^{168}$ In that situation, any "translation" that accommodates the change in presupposition will inevitably break faith with a Founding commitment of principle. That is precisely the dilemma presented by the Second Amendment. The principle of military decentralization - the avoidance of standing armies - was a cornerstone of the Founders' political theory; yet neither the courts' doctrine nor the revisionist alternative respect this principle. An interpretive practice based on "translation" may work well for technological changes such as the advent of broadcast media (in the First Amendment area) or electronic surveillance (in the Fourth Amendment area), but when a change in presupposition is brought about by deliberate, political choice at odds with the Founders' design - here, the creation of a wholly nationalized military at the expense of states' militia - then that change cannot simply be taken as a given. Before modern Second Amendment doctrine can be justified as a legitimate interpretive response to the withering of the states' militia, that change itself must be explained and defended. I attempt such a defense in the following Part.

\section{Dismantling The Founders' Framework}

My defense of the courts' doctrine hinges on the Fourteenth Amendment. The argument is that the Fourteenth Amendment should be read to abrogate the constitutional commitment to preservation of the states' militia. With this change, the original underpinnings of the Second Amendment disintegrated, justifying modern courts' extremely narrow reading of the Amendment. Modern statutes such as those banning private possession of machine guns and assault weapons are therefore perfectly valid, even though analogous laws in 1800 would have been plainly unconstitutional - not because we read the

168. Lessig anticipates this problem by defining a category of "political presuppositions" which reflect value judgments rather than factual beliefs. See Lessig, Fidelity in Translation, supra note 26, at 1254-55. Constitutional interpreters should not, according to Lessig, credit changes in such presuppositions. Id. This concession by Lessig eliminates a great deal of the explanatory power of his theory. As the example of the Second Amendment illustrates, most, if not all significant instances of doctrinal change in constitutional law are driven by changes in "political presuppositions." The interpretive methodology I advocate here seeks to identify those changes which are grounded in a constitutional amendment, and therefore ought to be taken into account by contemporary interpreters. 
Constitution differently today, but because the Constitution has changed in the interim.

To see the impact of the Fourteenth Amendment on the militia and therefore its impact on the Second Amendment - I will focus on the changing constitutional status of a federal draft. In Part I, I briefly described President Madison's proposal to draft soldiers for the War of 1812. Opponents, led by Daniel Webster, maintained that the draft was unconstitutional, and the proposal was defeated. I will argue below that Webster was correct. Madison's proposal was unconstitutional because national conscription would have destroyed the Founders' delicately balanced military system.

During the Civil War, however, President Lincoln succeeded where Madison had failed. He pushed through the Conscription Act of 1863 and implemented a federal draft. The Supreme Court eventually upheld the practice in the 1918 Selective Draft Law Cases. ${ }^{169}$

As with Madison's proposal, I believe the Conscription Act was unconstitutional - when enacted. One ramification of the Fourteenth Amendment, however, was to legitimize Lincoln's draft and his concomitant repudiation of the militia. In this way, the draft resembled a number of other Civil War innovations. For the Conscription Act was hardly Lincoln's only constitutional transgression. He almost certainly lacked authority to issue the Emancipation Proclamation; ${ }^{170}$ his imposition of an income tax was probably unconstitutional $;{ }^{171}$ his suspension of habeas corpus was declared so by the Supreme Court: ${ }^{172}$ and his issuance of paper money was constitutionally dubious at best. ${ }^{173}$

\footnotetext{
169. 245 U.S. 366 (1918).
}

170. That is a large claim and I do not intend to defend it here. Suffice it to say that Lincoln himself based his authority to issue the Proclamation entirely upon his status as Commander-in-Chief, writing privately that the Proclamation had no constitutional or legal justification, except as a military measure. 8 COMPLETE WORKS OF ABRAHAM LINCOLN 32 (John G. Nicolay and John Hay eds. 1905). In his main public defense of the Proclamation, Lincoln responded to charges of its unconstitutionality by stating: "I think differently. I think the constitution invests its Commander-in-chief with the law of war, in time of war." DAVID Herbert DONALD, LinCOLN 456 (1995) (quoting letter from Lincoln to James C. Conkling). It is also worth noting that Lincoln's first effort at emancipation was to propose constitutional amendments that were much less sweeping than his eventual Proclamation, see id. at 396-97, and that Justice Curtis - who had dissented in Dred Scott and who by 1862 had retired from the Supreme Court - wrote a pamphlet contesting the Proclamation's constitutionality. Alexander H. STEPhens, 2 A CONSTITUTIONAl View of THE LATE War Between the States 551-57 (Philadelphia, Nat'l Publ'g Co. 1870). See also James G. RANDALl, CONSTITUTIONAL PROBLEMS UNDER LINCOLN 373-78 (1926) (discussing Proclamation's constitutionality).

171. See Pollock v. Farmers' Loan and Trust Co., 157 U.S. 429 (1895) (declaring 1894 income tax law unconstitutional) (nullified by Sixteenth Amendment).

172. See Ex Parte Milligan, 71 U.S. 2 (1866).

173. The wartime Legal Tender Act was initially declared unconstitutional in Hepburn v. Griswold, 75 U.S. 603 (1870), but the Court quickly reversed itself in the Legal Tender Cases, 79 U.S. 457 (1871) (reversing Hepburn). I would argue that the holding in the Legal Tender Cases depends mainly on the Civil War Amendments - but that argument will have 
But of course we do not regard Abraham Lincoln as a rogue president. All readers of this Article understand that Lincoln and the Reconstruction Congress which followed him were agents of a monumental constitutional change. My argument here is that this change embraced military structure as well as the more familiar issues of equality and individual liberty. Just as the Thirteenth Amendment ratified the Emancipation Proclamation, and the Fourteenth ratified the Civil Rights Act of 1866, so too did the Fourteenth Amendment legitimize conscription. Lincoln's repudiation of the militia system fit perfectly with the larger principles for which the Civil War was fought. After the military defeat of States' Rights proponents at the hands of Unionists, the Founders' notion of militia as protection against national despotism was no longer tenable. From the perspective of the Unionists who wrote the Fourteenth Amendment, the Southern states' militia were an instrument of, not a remedy for, tyranny. To the Founding Federalists, the states' militia had symbolized freedom; to the Reconstruction Republicans, the states' militia symbolized slavery and rebellion. In this view, both Daniel Webster and the Selective Draft Law Cases were correct - because the Constitution of 1918 was not (and the Constitution of 2000 is not) the Constitution of 1812.

\section{A. The Civil War Watershed}

The decisive break with the Founders' principles took place during the middle of the Civil War. In the early stages of the conflict, President Lincoln drew on both of the options made available by the Founders. He directed the Army to enlist as many volunteers as could be found, while at the same time making repeated calls on the states for militia. ${ }^{174}$ But these methods could not supply the enormous number of soldiers needed to prosecute the war, as the number of volunteers dwindled and states proved unable or unwilling to furnish the number of militiamen called for by the president. ${ }^{175}$ In 1862 , Lincoln made his first, tentative break with the Founders' conception: He proposed, and Congress adopted, a statute authorizing the president to

to await another day. For criticisms of the Legal Tender Cases, see ROBERT BORK, THE Tempting of AMERICA: The Political SeduCTION OF THE LAw 155 (1990); Kenneth W. Dam, The Legal Tender Cases, 1981 SuP. CT. REV. 367 (1982); Peter B. McCutchen, Mistakes, Precedent, and the Rise of the Administrative State: Toward a Constitutional Theory of the Second Best, 80 CORNELL L. REV. 1, 17 (1994).

174. See JAMES M. MCPHERSON, BATtLe CRY OF THE REPUBliC 322-26, 490-94; MAHON, supra note 32, at 97-107; CHAMBERS II, supra note 32, at 42-49.

175. When Lincoln took office in 1860 , the national army consisted of only 16,000 soldiers. See MAHON, supra nute 32, at 97; ERIC FONER, RECONSTRUCTION 23 (1988). By 1862, more than 700,000 men had joined the Union Army, MCPHERSON, supra note 174 , at 322 , and during the course of the war some $2,100,000$ soldiers would fight on the Union side, $i d$. at 306 n. 41 . 
compel states to draft a specified number of militiamen into service. ${ }^{176}$ Lincoln never used this authority, as the statute had its desired effect; the states fulfilled their quotas. The next year, however, with the need for fresh troops unabated, Lincoln was forced to make a more dramatic proposal, the Conscription Act of $1863 .{ }^{177}$

Just as Webster and the Hartford Convention had fifty years earlier, Lincoln's opponents insisted conscription was unconstitutional. ${ }^{178}$ If the men of the United States need to be called to war, these opponents argued, the proper way to do so is by calling out the militia. The Conscription Act ignored this constitutional directive by drafting Americans directly into the national army. In the face of the urgent military necessity for conscription, however, these protestations were to no avail. The opponents were denounced as copperheads, and the bill passed overwhelmingly. ${ }^{179}$

Enacting the law was only half the battle; the next step was enforcing it. In New York, Governor Horatio Seymour threatened to block implementation of the Act. Seymour backed away from his threat just before the Act took effect - but he warned that "the bloody and treasonable doctrine of public necessity can be proclaimed by a mob as well as by the government," and initial efforts to begin the draft sparked four days of vicious rioting. ${ }^{180}$ It took a garrison of 20,000 federal soldiers to restore order and permit the draft to go forward. ${ }^{181}$

Matters went further in Pennsylvania. In an extraordinary proceeding, the Pennsylvania Supreme Court took jurisdiction over a suit by draftees challenging the Conscription Act, Kneedler v. Lane. ${ }^{182} \mathrm{By}$ a 3-2 majority, the Court declared the Act unconstitutional and authorized a preliminary injunction against its enforcement. Chief Justice Lowrie termed the conscripted federal army "an unauthorized substitute for the militia of the states." 183 A crisis was averted, however, after elections in Pennsylvania enabled a change in the composition of

176. Act of July 17, 1862, 12 Stat. 597. See MCPHERSON, supra note 174, at 492-93; MAHON, supra note 32, at 100-01.

177. Act of March 3, 1863, ch. 75, 12 Stat. 731. Incidentally, the Union's difficulties in raising troops demonstrate James Madison's acuity in Federalist 46, in which he predicted that state militias would far outnumber even the largest federal army that could be amassed with volunteers. See supra note 63 and text accompanying note 204 .

178. See infra notes $200-13$ and accompanying text.

179. See CONG. GloBE, 37th Cong., 3d Sess. 1391 (1863) (Senate approved Conscription Act by vote of 35-6); CONG. GLOBE, 37th Cong., 3d Sess. 1268-69 (1863) (use of "copperhead" epithet).

180. See MCPHERSON, supra note 174 , at $609-11$.

181. See id. at 611 .

182. 45 Pa. 238 (1863); see also J.L. Bernstein, Conscription and the Constitution: The Amazing Case of Kneedler v. Lane, 53 A.B.A. J. 708 (1967).

183. Kneedler, $45 \mathrm{~Pa}$. at 245. 
the Pennsylvania Court. Chief Justice Lowrie's term expired shortly after the Kneedler decision, and Governor Andrew Curtin, a staunch Lincoln ally who had just won reelection, appointed a Republican to replace him - thus tipping the balance of the Court in favor of the President. ${ }^{184}$ The Court met immediately to dissolve the injunction; this time, the 3-2 vote went in favor of Lincoln and the draft. ${ }^{185} \mathrm{En}-$ forcement of the Conscription Act went forward.

Chief Justice Taney apparently expected a suit similar to Kneedler to reach the United States Supreme Court; in anticipation, he prepared a draft opinion finding the Conscription Act unconstitutional. ${ }^{186}$ But the suit never came, and it was not until the Selective Draft Law Cases $^{187}$ in 1918 that the Supreme Court finally ruled on the issue (although the Supreme Court made passing references to conscription, without suggesting any disapproval, as early as $1865^{188}$ ). The issue in that case was the validity of a draft law enacted during World War I. The plaintiffs, echoing Daniel Webster and the Pennsylvania Justices, argued that the draft law "infringe[d] ... [the] reserved right of the States over the militia." 189 Rejecting that argument, a unanimous Court upheld the law. ${ }^{190}$

184. See Bernstein, supra note 182 , at 712 In winning reelection, Curtin defeated a challenge by none other than Pennsylvania Supreme Court Justice George Woodward, who had engineered that court's unusual proceeding in Kneedler. This election, along with those taking place simultaneously in other states, was understood nationwide as a crucial referendum on Lincoln's leadership and his prosecution of the war. "A prominent Democrat campaigning for Woodward declared that when elected he would unite with Governors Vallandigham of Ohio and Seymour of New York (representing together nearly half of the North's population) 'in calling from the army troops from their respective States for the purpose of compelling the Administration to invite a convention of the States to adjust our difficulties." " MCPHERSON, supra note 174, at 685; see also DONALD, supra note 170, at 454-55.

185. Kneedler, $45 \mathrm{~Pa}$. at 238.

186. See Roger B. Taney, Thoughts on the Conscription Law of the United States, in THE MILITARY DRAFT: SELECTED READINGS ON CONSCRIPTION 208 (Martin Anderson ed., 1982).

187. The Selective Draft Law Cases, 245 U.S. 366 (1918).

188. See United States v. Murphy, 70 U.S. 649 (1865); United States v. Scott, 70 U.S. 642 (1865). Also, Tarble's Case, in 1872, contains dicta explicitly approving the federal draft: "Now, among the powers assigned to the National government, is the power 'to raise and support armies'... [I]ts control over the subject is plenary and exclusive. It can determine, without question from any State authority, how the armies shall be raised, whether by voluntary enlistment or forced draft ...." 80 U.S. 397, 408 (1872). This observation is made in passing, without any supporting argument.

189. 245 U.S. at 372 (Court's summary of party arguments).

190. Id. at 382 ("The fallacy of the argument results from confounding the constitutional provisions concerning the militia with that conferring upon Congress the power to raise armies. It treats them as one while they are different."). 


\section{B. The Original Understanding of Conscription}

Today, more than eighty years after the Selective Draft Law Cases and with the constitutionality of the draft well-established, the arguments against conscription may strike some readers as implausible. Yet as a matter of original intent, Lincoln's opponents were almost certainly correct. The Conscription Act was inconsistent with the Founders' Constitution. It made nonsense of the carefully crafted Militia Clauses of Article I, and of the Second Amendment designed to protect and implement them. Every indicator of original intent - text, legislative history, contemporary practice and constitutional structure - argues against a national draft. ${ }^{191}$

\section{Text}

Proponents of the Conscription Act based their constitutional argument on the clause authorizing Congress to "raise and support Armies," ${ }^{192}$ together with the Necessary and Proper Clause. ${ }^{193}$ Their argument was straightforward: Because the federal government is permitted to maintain an army, it must be allowed to conscript soldiers to staff that army. Or as the court later put it in the Selective Draft Law Cases: "As the mind cannot conceive an army without the men to compose it, on the face of the Constitution the objection that it does not give power to provide for such men would seem to be too frivolous for further notice." 194

But the question is not whether Congress may provide for such "men" at all - that separate question was indeed settled by the Founders after the extensive debate recounted in Part I - but how Congress may provide for them. The answer is that the Founders envisioned that any federal army would be "raise[d]" the way "Armies" were always raised at that time: by voluntary enlistment. As we saw earlier, the dichotomy between armies and the militia was central to the Founders' thought - and this dichotomy was enshrined in the constitutional text. The federal government was authorized to "raise... Armies"195 at will, but permitted to "call[] forth the Militia" ${ }^{196}$ only under certain specified conditions. By contrast, states were

191. Other scholars have dealt with this issue more comprehensively than I do here, with the same conclusion. See Harrop A. Freeman, The Constitutionality of Direct Federal Military Conscription, 46 IND. L.J. 333 (1971); Friedman, supra note 151; see also AMAR, supra note 9, at 56-59. As the dates of the Friedman (1969) and Freeman articles suggest, debate over the draft's constitutionality revived during the Vietnam War.

192. U.S. CONST, art. I, $\S 8$, cl. 12.

193. U.S. CONST. art. I, $\S 8$, cl. 18.

194. 245 U.S. at 377.

195. U.S. CONST. art. I, $\S 8, \mathrm{cl} .12$.

196. U.S. CONST. art. I, $\$ 8$, cl. 15 . 
expressly forbidden to "keep Troops [a synonym for armies] ... in time of Peace,"197 but they were expected to maintain and "train[] the Militia" ${ }^{198}$ continually.

This army/militia dichotomy had several dimensions, but for present purposes the key distinction was that army service was voluntary but militia service was compulsory. As Taney's never-used draft opinion describes, this distinction was part of the very meaning of the terms:

The power to do this [i.e., conscript] is, I understand, claimed under the clause which gives Congress the power to raise and support armies... But ... the words themselves, even if they stood alone, will not, according to their known and established use and meaning in the English language, justify [this construction].

During the period when the United States were English Colonies, the Army of England, - the standing army, - was always raised by voluntary enlistments ... and when the power to raise and support armies was delegated to Congress, the words of the grant necessarily implied that they were to be raised in the usual manner. - And the general government has always heretofore so understood them and has uniformly by its own officers recruited the ranks of its "land forces" by voluntary enlistments for a specified period. ${ }^{199}$

The distinction between an enlisted army and a conscripted militia was also built into the architecture of the Constitution's military provisions, as opponents of the Conscription Act saw clearly. During debate on the Act, Senator James Bayard of Delaware led his colleagues through a careful and detailed examination of the military clauses, concluding: "If the power of Congress exists to call the entire ablebodied population of the United States into the standing regular Army of the United States by conscription, what is there left, and where was the necessity for these provisions as to the organization of the militia?"200 Giving Congress the power to conscript, Bayard argued, would obviate its powers to call forth the militia ${ }^{201}$ and to prescribe a training "discipline" for them, ${ }^{202}$ and would nullify the Founders' carefully crafted limits on those powers. One of the Kneedler Justices put it succinctly: "[I]f we concede this dangerous power to the language of the 13th [Raise Armies] clause, we destroy the force and effect of the words of the 16th and 17th [Militia] clauses." ${ }^{203}$

\footnotetext{
197. U.S. CONST. art. I, $\S 10$, cl. 3.

198. U.S. ConST. art. I, $\S 8$, cl. 16.

199. Taney, supra note 186, at 213.

200. CONG. Globe, 37th Cong., 3d Sess. 1364 (1863) (statement of Sen. Bayard).

201. U.S. CONST. art. I, § 8, cl. 15.

202. U.S. CONST. art. I, § 8, cl. 16.

203. Kneedler v. Lane, 45 Pa. 238, 257 (1863) (Woodward, J., concurring).
} 


\section{Legislative History}

The ratification debates confirm that this was not the Founders' intent. Recall, for example, Madison's confidence in the passage quoted earlier from The Federalist No. 46 that in the event of any attempted coup by federal officials, the militia - "near half a million of citizens" - would easily defeat an army that, at most, would number "twentyfive or thirty thousand men." ${ }^{204}$ Behind Madison's arithmetic is the premise that the national government will be forced to rely on enlistees for its army - and that only a tiny fraction of the population will voluntarily sign up to fight - while the states can conscript their entire male citizenry.

Recall, too, Anti-Federalist fears that the federal government would "harass" and "abuse" militiamen by marching them from Maryland to Maine and subjecting them to harsh military law. These charges were directed at the constitutional language authorizing Congress to call forth the militia, and to prescribe a "discipline" for training the militia, powers that the Philadelphia delegates had carefully limited in duration and scope. The outcry would have been orders of magnitude louder had any among the Founders believed the federal government could conscript soldiers directly, at any time and for any reason. Leon Friedman puts this point more broadly: "Further evidence that none of the founders thought power had been granted to conscript into a federal army is the fact that even the most vociferous Antifederalists never raised this spectre in attacking the new Constitution."205

Indeed, the rhetoric of Lincoln's opponents often bore a striking resemblance to Anti-Federalist speeches in defense of the militia. Thus Representative S.S. Cox complained: "By this bill you leave no power in the States to officer or direct their militia. The troops of Ohio may be mingled miscellaneously with those from Maine."206 Similarly, the Kneedler opinion echoed the Founders' vision: "Under the militia system, every man goes out with his neighbors and friends, and under officers with whom he is acquainted."207 The Conscription Act was wholly inconsistent with that vision.

204. The Federalist No. 46, at 299 (James Madison) (Clinton Rossiter ed., 1961).

205. Friedman, supra note 151 , at 1525 . Friedman thus concludes, "The idea of a direct draft by a central government acting upon every citizen without the intervening authority of the state governments was firmly and totally rejected even at the darkest moments of the Revolution." Id. at 1510 .

206. Cong. GloBe, 37th Cong., 3d Sess. 1269 (1863) (statement of Rep. Cox).

207. $45 \mathrm{~Pa}$. at 248-49. 


\section{Contemporary Practice}

Besides text and history, Founding-era practice argues against the draft. Prior to 1863 , the federal government had mobilized military forces only through the two methods envisioned by the Constitution: voluntary enlistment and calling forth the states' militia. The one effort to depart from this practice - Madison's proposed draft in 1815 - was firmly rejected. ${ }^{208}$ Thus as Senator Bayard charged, the Conscription Act broke sharply with precedent: "For the first time in the history of this country, the bill proposes, by conscription ... to force every able-bodied citizen of the United States, capable of enduring the fatigues of war, into the Army of the United States, the regular standing Army of the United States."209

\section{Constitutional Structure}

Most important, as we saw in Part I, the constitutional text and the Founders' practice were undergirded by a principled commitment to a (partially) decentralized military structure, with power divided between a federal army and the states' militia. The single strongest argument against the Conscription Act was that it undercut this commitment entirely. Lincoln's opponents declared repeatedly that conscription "obliterates the militia system ... and substitutes in place of that system, standing armies." 110

The essential vice of the Conscription Act was that it ignored the constitutional mandate putting the militia under the control of the states. "[I]t takes that very state force, strips it of its officers, despoils it of its organization, and reconstructs its elements under a different authority." 211 This invited precisely the dangers the Federalists had struggled to avoid: tyranny and military adventurism. Senator David Turpie, an Indiana Democrat, detailed how, throughout the nation's seventy-year history, the states had played a vital, intermediary role in checking federal power:

208. See supra notes $94-99$ and accompanying text.

209. Cong. Globe, 37th Cong., 3d Sess. 1363 (1863) (statement of Sen. Bayard); see also id. at 1363-64 ("[The bill] does not propose that Congress shall act under that provision of the Federal Constitution which authorizes the ... calling [of] the militia of the several States into active service ... . The bill has no such object .... [The bill] utterly abandons and subverts the militia system of the United States... and substitutes in place of that system standing armies."); Kneedler, $45 \mathrm{~Pa}$. at 272 ("During the Whiskey Insurrection in this state, President Washington called upon the militia [to suppress the rebellion], by a requisition on the governor, and in person commanded them. So the militia were called out from many of the states during the war with Great Britain, and in every instance a requisition made by the President upon the governors of the states.").

210. CONG. GLOBE, 37th Cong., 3d Sess. 1364 (1863) (statement of Sen. Bayard).

211. Kneedler, $45 \mathrm{~Pa}$. at 245. 
Here is a plain attempt to obliterate one step which has always heretofore been observed and regarded; a step that has always been taken in calling into the field the military forces of the Republic. It belongs to history that armies heretofore have been raised by requisitions of the Executive upon the authorities of the States....

In the War of $1812, \ldots$ [Massachusetts] refused to furnish her quota for carrying on that war. In the war with Mexico, some of the New England States also refused and declined. ...

In this war, the authorities of Kentucky and Massachusetts refused and declined to obey the requisition of the President of the United States, and so did the authorities of other States....

It is a part of the constitutional law of the country that a requisition must be made on the State authorities by the national Executive for military forces within the control of the States. Senators talk about the militia of the United States. There is no such thing in existence. The militia belongs to the States. ${ }^{212}$

At bottom, then, the infirmity of the Conscription Act lay in its repudiation of the military checks-and-balances designed by the Founders. In the words of Representative Cox:

I believe that this bill not only subverts the State governments, but that it will oppress the people. It breaks down the barrier which the people erected against consolidated power; for never in the history of this or any other Government has such a stupendous power been reposed in one man as the power reposed by this bill in the President of the United States. ${ }^{213}$

\section{The Fourteenth Amendment's Legitimation of the Draft}

But once we understand the ways in which conscription broke with the Founders' plan, we can begin to see why the Fourteenth Amendment must be understood to legitimize the draft. Imagine how the Founders' concerns about federal tyranny and military adventurism must have seemed to Lincoln and the Reconstruction Republicans. First, and most obviously, the Founders' main fear - that a President might use a national standing army to impose his will on dissident states - was moot. Their plan had failed. The Civil War — or, to

212. CONG. GLOBE, 37th Cong., 3d Sess. 1367 (1863) (statement of Sen. Turpie). Senator James Bayard elaborated the point further:

Heretofore it has been always held that the reserved force of the nation is the militia of the several States, which can be called into its service by the President of the United States under the provisions that Congress may adopt for that purpose; but when you call that militia into service, you call them in, not as individuals, but as organized bodies of men, to be commanded, under the express provision of the Constitution, by officers appointed by the States, and to be disciplined under the discipline that Congress prescribes, by the State authorities alone....

Id. at 1363 (statement of Sen. Bayard).

213. CONG. GLOBE, 37th Cong., 3d Sess. 1270 (1863) (statement of Rep. Cox). 
paraphrase Confederate terminology, the War Between Some of the States and the Federal Government - was precisely the eventuality the Founders' structure was designed to prevent.

Even more fundamentally, from the vantage point of Civil War Unionists, not only was the Founders' plan obsolete, but its premises were mistaken. By 1866, it was simply no longer possible to view the states and their militias as the Founders had. To the Founders, the states were bulwarks of liberty; to the Republicans, the (southern) states were defenders of slavery, and their militias, the Confederate Army, had killed some 360,000 Union soldiers in that cause. ${ }^{214}$ The political-theory foundation of the Militia Clauses and the Second Amendment had turned to dust.

It is with this perspective that we should read the Fourteenth Amendment as having retroactively ratified Lincoln's military innovations. The Amendment does not, of course, expressly mention the draft, or even the militia or the army. It did not repeal the Militia Clauses in the way that the Twenty-First Amendment repealed the Eighteenth. With the Fourteenth Amendment's "majestic generalities," 215 however, its framers were seeking to consolidate the Union's victory in the Civil War. The Amendment was drafted initially by the congressional Joint Committee on Reconstruction; the Committee's mission was to set the terms on which the re-United States would go forward. ${ }^{216}$ It is unthinkable that those who framed and ratified the Fourteenth Amendment expected the military balance of power between the states and the federal government to revert to the status quo ante bellum.

Let me now try to flesh out this reading of the Amendment using the traditional tools of text, history and structure. The textual argument takes as its point of departure the Citizenship Clause of the Fourteenth Amendment; the argument is that by redefining citizenship as a national, rather than state, concept, the Amendment made Americans subject to a federal draft. The argument from legislative history is simply that the Republican Congress gave full consideration to the constitutional arguments for and against a draft, and decided in favor of the draft, in its debate over the Conscription Act itself. The structural argument is that granting the federal government power to conscript is consistent with the Fourteenth Amendment's partial repudiation of the Founders' state-centered federalism.

214. See MCPHERSON, supra note 174 , at 854.

215. Fay v. New York, 332 U.S. 261, 282 (1947).

216. See William E. Nelson, The Fourteenth Amendment 48-63 (1988). 


\section{Text: Military Service as a Duty of "Citizens of the United States"}

The Amendment's opening sentence declares: "All persons born or naturalized in the United States, and subject to the jurisdiction thereof, are citizens of the United States and of the State wherein they reside." 217 The specific impetus for this provision, of course, was to overturn the Supreme Court's decision in Dred Scott $v$. Sandford, which had held that African Americans were forever barred from U.S. citizenship. ${ }^{218}$ But the impact of the change was far broader. As Justice Field explained in the Slaughter-House Cases, decided shortly after enactment of the Fourteenth Amendment:

The first clause of this amendment determines who are citizens of the United States, and how their citizenship is created. Before its enactment there was much diversity of opinion among jurists and statesmen whether there was any such citizenship independent of that of the State, and, if any existed, as to the manner in which it originated. With a great number the opinion prevailed that there was no such citizenship independent of the citizenship of the State....

In the Dred Scott case this subject of citizenship was fully and elaborately discussed. The exposition in the opinion of Mr. Justice Curtis has been generally accepted by the profession of the country as the one containing the soundest views of constitutional law. And he held that, under the Constitution, citizenship of the United States in reference to natives was dependent upon citizenship in the several States, under their constitutions and laws....

The first clause of the [F]ourteenth [A]mendment changes this whole subject, and removes it from the region of discussion and doubt. It recognizes in express terms, if it does not create, citizens of the United States, and it makes their citizenship dependent upon the place of their birth, or the fact of their adoption, and not upon the constitution or laws of any State or the condition of their ancestry. A citizen of a State is now only a citizen of the United States residing in that State. The fundamental rights, privileges and immunities which belong to him as a free man and a free citizen, now belong to him as a citizen of the United States, and are not dependent upon his citizenship of any State. ${ }^{219}$

As this excerpt indicates, the most obvious consequence of the new constitutional category of "citizens of the United States" was to create the possibility of "rights, privileges, and immunities" attendant to national citizenship - and almost all of the jurisprudential debate about

217. U.S. CONST. amend. XIV, $\$ 1$.

218. 60 U.S. (19 How.) 393 (1857); see also The Slaughter-House Cases, 83 U.S. (16 Wall.) 36, 73 (1872) (noting that the "main purpose" of Section 1 of the Fourteenth Amendment was to "establish the citizenship of [former slaves and other free AfricanAmericans]").

219. Slaughter-House Cases, 83 U.S. at 94-95. 
the Fourteenth Amendment, from Slaughter-House to Roe v. Wade . $^{220}$ to Saenz $v$. Roe, ${ }^{221}$ has concerned the scope of these rights. But citizenship has duties as well as rights, and central among these is the obligation of military service - indeed, it is "one of the highest duties of the citizen,"222 as the Court put it in Dred Scott itself. Prior to the Fourteenth Amendment, an American fulfilled this duty by serving in the state militia. Ever since, the duty has run to the federal government as well.

The constitutionality of the draft, then, can be linked directly to the Fourteenth Amendment's revolution in the constitutional concept of citizenship. In fact, a careful reading of the Court's opinion in the Selective Draft Law Cases shows some evidence of this linkage. The opinion, authored by Justice White, bases its holding primarily on the Raise Armies Clause ${ }^{223}$ - as we have seen, this argument is unpersuasive. White also, however, makes a secondary argument based on citizenship. In its brief, the United States had argued that: "The highest duty of the citizen is to bear arms at the call of the nation. This duty is inherent in citizenship." 224 This argument would have been considerably more difficult, if not impossible, to make before the Fourteenth Amendment. But writing in 1918, Justice White easily adopted the argument. His opinion began by rejecting the plaintiffs' claim that a draft is "repugnant to free government .... It may not be doubted that the very conception of a just government and its duty to the citizen includes the reciprocal obligation of the citizen to render military service in case of need and the right to compel it."225 White then proceeded to examine the claim that only the states can draft soldiers. After reviewing the history of Civil War conscription, White wrote:

[W]e briefly direct attention to th[e Fourteenth] Amendment for the purpose of pointing out, as has been frequently done in the past, how completely it broadened the national scope of the Government under the Constitution by causing citizenship of the United States to be paramount and dominant instead of being subordinate and derivative, and therefore, operating as it does upon all the powers conferred by the Constitution, leaves no possible support for the contentions made ....226

After writing most of the opinion as if it were 1789, White's final dismissal of the militia-based argument against the draft rests on an oblique but unmistakable suggestion that the military clauses of the

\footnotetext{
220. 410 U.S. 113 (1973).

221. 526 U.S. 489 (1999).

222. Dred Scott, 60 U.S. at 415.

223. See 245 U.S. 366,377 (1918).

224. $I d$. at 368 (summarizing the government's brief).

225. Id. at 378 .

226. Id. at 389 (citation omitted).
} 
original Constitution must be reinterpreted in light of the Fourteenth Amendment.

\section{Legislative History: The Relationship Between the Conscription Act and the Fourteenth Amendment}

Now consider the Amendment's legislative history. I concede at the outset that congressional debates on the Fourteenth Amendment give no indication that it was expected to alter the Constitution's military structure. Yet if we look to elements of the legislative history beyond these debates, the case for my reading grows stronger.

The most important element of this legislative history is the passage of the Conscription Act itself, just a few years before adoption of the Fourteenth Amendment. ${ }^{227}$ As we have seen, that Act provoked a lengthy and sophisticated debate on the constitutionality of the draft. This debate was conducted not only in the congressional chambers, but also among the public. Needless to say, public interest in the proposal was intense. Yet despite the opponents' arguments, and after a thorough airing of the issue, decisive majorities approved the bill.

Of course, the mere fact that congressional majorities believe a bill is constitutional does not make it so. Rather, the relevance of the Conscription Act debate lies in the fact that most of the Senators and Representatives who voted for the Fourteenth Amendment had voted for the Conscription Act as well. For these men, and for the citizens who stood behind them, the war had forced the conscription question upon them; they had confronted the constitutional objections, and a decision had been made.

To be clear, I am not claiming that the framers of the Fourteenth Amendment consciously saw the Amendment as constitutionalizing the Conscription Act - as they did, by contrast, with the Civil Rights Act of $1866 .{ }^{228}$ With the latter, even those who voted for it felt the need to dispel doubts about its legitimacy by constitutional amendment. ${ }^{229}$ With the Conscription Act, on the other hand, the few years between its passage and the Fourteenth Amendment had more firmly established the Act's legitimacy. After the initial difficulties implementing the draft, it had become a settled, if never popular, practice.

Thus while it would be imprecise to speak of a "framers' intent" that the Fourteenth Amendment would authorize conscription, I do

227. The Conscription Act was enacted in 1863. The Fourteenth Amendment was approved by Congress in 1866 and was ratified by 1868 .

228. See RaOul Berger, Government By JudiCiary 20 (stating that "all are agreed [that] it was the purpose of the [Fourteenth] Amendment to embody and protect" the Civil Rights Act of 1866).

229. See CONG. GloBE, 39th Cong., 1st Sess. 1291 (1866) (statement of Rep. Bingham); NELSON, supra note 216, at 48. 
contend that the framers of the Amendment presumed federal authority to conscript. Had Chief Justice Taney gotten the chance to issue his draft opinion, we can suppose that the Fourteenth Amendment would have included language intended specifically to overturn that ruling, just as it contained language designed to overturn Dred Scott and to bolster the Civil Rights Act of $1866 .{ }^{230}$ Again, Justice White's Selective Draft Law Cases opinion contains a subtle reference to this history. The opinion gives an extended description of the Conscription Act of 1863, concluding that "it was the efficient aid resulting from the forces created by the draft at a very critical moment of the civil strife which obviated a disaster which seemed impending and carried that struggle to a complete and successful conclusion." ${ }^{231}$ By 1918, the Court was manifestly unwilling to undo the Civil War precedent.

Additional elements of legislative history confirm further that $\mathrm{Re}$ construction Republicans held views of the army and the militia diametrically opposite those of the Founders. The Republicans saw the national army as the savior of the Union, and the guarantor of freedmen's rights in the to-be-reconstructed South. In February 1867, shortly after proposing the Fourteenth Amendment, Congress reimposed military rule on the southern states and required those states to approve the Amendment as a condition of readmission to the Union. ${ }^{232}$ Throughout the ratification period, then, a federal army composed partly of conscripted soldiers occupied the South.

The Republicans' view of the militia, meanwhile, is evident in two key pieces of Reconstruction legislation: the Civil Rights Act of $1866^{233}$ and the Enforcement Act of 1871. ${ }^{234}$ The Reconstruction Congress knew that the southern states would seek to oppress freed slaves not only through the Black Codes and similar legislation (which the Fourteenth Amendment was designed to invalidate), but also by using terror and brutality to enforce white supremacist social and political practices. ${ }^{235}$ Thus the Civil Rights Act made it a federal crime for anyone acting "under color of any law" to violate the rights of freed slaves, or to subject them to "punishment, pains, or penalties" other than as a consequence of legal conviction. ${ }^{236}$ The Enforcement Act ex-

230. See supra notes $218,228,229$, and accompanying text.

231. The Selective Draft Law Cases, 245 U.S. 366, 387 (1918).

232. Act of March 2, 1867, ch. 153, 14 Stat. 428; see also FONER, supra note 175, at 73-75.

233. Act of April 9, 1866, ch. 31, 14 Stat. 27.

234. Act of April 20, 1871, ch. 22, 17 Stat. 13.

235. Cf. AMAR, supra note 9, at 166 (arguing that the use of "or enforce" in the Fourteenth Amendment shows intention to limit state executive action as well as legislative action).

236. Act of April 9, 1866, ch. 31, §2,14 Stat. at 27. 
tended these provisions by exposing rights violators to civil liability; ${ }^{237}$ this provision is the predecessor to 42 U.S.C. $\S 1983$.

These statutes were aimed directly at state law enforcement agents and quasi-official entities such as the militia. As Carl Bogus has demonstrated, one of the militia's primary functions in the prewar South was to enforce the Slave Codes. ${ }^{238}$ Reconstruction Republicans undoubtedly anticipated that southern militias would continue to be agents of racial oppression in the postwar period. ${ }^{239}$

Perhaps the clearest sign of the post-Civil War view of the militia comes from the sections of the Enforcement Act aimed at the Ku Klux Klan. In the decades following the Civil War, the Klan was the closest thing to an "unorganized militia" in the United States. Yet no one could confuse the Klan with the liberty-protecting citizen-soldiers of the Founders' ideology. To the Reconstruction Republicans, certainly, it was clear that the Klan's reign of terror threatened fundamental constitutional (that is, Fourteenth Amendment) values. Accordingly, the Enforcement Act broadened its focus beyond those acting "under color of law." It also criminalized private conspiracies "for the purpose, either directly or indirectly, of depriving any person or any class of persons of the equal protection of the laws, or of equal privileges or immunities under the laws." 240

The Enforcement Act - so called because it was styled "An Act to enforce the provisions of the Fourteenth Amendment to the Constitution of the United States"241 - nicely captures the changing constitutional status of the militia. To the Founders, the militia symbolized freedom and liberty. To the Reconstruction Republicans, the term "militia" connoted not just rebellion, but Klan violence and racial oppression as well.

\section{Structure: The Demise of the Founders' Federalism}

Finally, reading the Fourteenth Amendment to legitimize the draft meshes perfectly with the broader structural principles underlying the Fourteenth Amendment. The Republicans' reversal of the Founders'

237. Act of April 20, 1871, ch. 22, $§ 1,17$ Stat. 13 .

238. See Bogus, Hidden History, supra note 3, at 335-37. Interestingly, though, historian Peter Voelz has uncovered several instances during the colonial period in which South Carolina actually armed slaves to fight as soldiers. See PETER M. VOELZ, SLAVE AND SOLDIER: THE MILITARY IMPACT OF BLACKS IN THE COLONIAL AMERICAS 24-27 (1993).

239. See FONER, supra note 175, at 203 ("[S]tate militias [were] intended, as a Mississippi white put it in 1865 , to "keep good order and discipline amongst the negro population." ").

240. Act of April 20,1871, ch. 22, §2.

241. Id. 
preference for the militia over the army was part of their larger program for revamping the Founders' federalism.

The Founders' division of power between the national army and the states' militias mirrored their overall allocation of power between the federal government and the states. The guiding principle adopted by the Philadelphia Convention was that the federal government's authority should extend only to "cases to which the several states are incompetent."242 As Madison famously put it in the Federalist: "The powers delegated by the proposed Constitution to the federal government are few and defined.... The powers reserved to the several States will extend to all the objects which, in the ordinary course of affairs, concern the lives, liberties and properties of the people. . ."243

This allocation was rooted in a political theory that saw the federal government as the main threat to liberty in the new structure. This was obviously the view of the Anti-Federalists who wanted no central government at all, or only a very limited one. ${ }^{244}$ But the Federalist supporters of the new Constitution also shared this perspective, albeit to a lesser degree. To be sure, the Federalists did want to establish a central government. The states by themselves would be militarily weak, inviting European hegemony; ${ }^{245}$ in the absence of federal coordination, collective-action problems among the states could strangle commerce ${ }^{246}$ and in the worst case, the thirteen independent states would fight bloody wars for domination of the continent. ${ }^{247}$

Yet these concerns did not reflect a mistrust of the state governments themselves. The Founders feared a "disunited America,"248 but as between the states and the new federal government, they plainly favored the states. In the context of a federalist system, they were confident that the "most natural attachment of the people will be to the governments of their respective States." 249 Many of the state governments (in their colonial form) were more than one hundred years old, and all had been around for several decades; the federal government was new and untested. The state governments were already bound by charters or constitutions, almost all of which had been rewritten since the Revolution began. ${ }^{250}$ Most important, the size of the new nation

242. 2 FARRAND, supra note 48 , at 229 (Virginia Plan as approved by Committee of the Whole).

243. The Federalist No. 45 at 292-93 (James Madison) (Clinton Rossiter ed., 1961).

244. See generally CORNELL, supra note 30.

245. See The Federalist No. 3 (John Jay); The Federalist No. 4 (John Jay).

246. See THE FEDERAlist No. 11 (Alexander Hamilton).

247. See The Federalist No. 5 (John Jay); The Federalist No. 6 (Alexander Hamilton).

248. See The Federalist No. 3, at 42 (John Jay) (Clinton Rossiter ed., 1961).

249. See ThE Federalist No. 46, at 294 (James Madison) (Clinton Rossiter ed., 1961).

250. See WoOD, supra note 110. 
deeply concerned many Founders, because of the "distance" it would create between the government and the governed. This distance was both geographical - unavoidably, federal representatives would be several days' travel time from many of their constituents - and metaphorical, in that the interests of many parts of the new country would be quite distant from those of other parts. ${ }^{251}$

For all these reasons, the Founders saw the main threat to liberty under the new Constitution as coming from the federal government, not the states. Accordingly, the original Constitution left the power of the states largely undisturbed. ${ }^{252}$ Not entirely - the Constitution did expose state law to federal preemption, ${ }^{253}$ and it did impose a few direct limits on states. ${ }^{254}$ But the document's main restrictions, from the specific guarantees of the Bill of Rights to the broad principles of separation and enumeration of powers, applied only to the federal government.

Indeed, not only were the Founders' untroubled by state power, but they actively saw the states as bulwarks against federal overreaching. In an age before modern political parties, the state governments were ready-made political organizations, continually prepared to challenge oppression by the federal government. Again, this vision is elaborated by Madison in The Federalist No. 46:

251. I acknowledge a strand of Federalist thought that distrusted the states even more than the federal government. Most famously, Charles Beard showed that many Federalists feared nascent populism in the post-Revolutionary state governments, and sought to protect basic property rights. See CHARLES A. BEARD, AN ECONOMIC INTERPRETATION OF THE CONSTITUTION OF THE UNITED STATES (1913); $c f$. WOOD, supra note 110 , at 475-83 (describing Federalists' concern over "social mobility"); U.S. CoNST. art. I, \& 8, cl. 4 (conferring authority over bankruptcy law on federal government); U.S. CONST. art. I, $\$ 10$, cl. 1 (prohibiting states from "impairing the Obligation of Contracts").

More generally, Madison's Federalist No. 10 - which today is probably the single bestknown articulation of Federalist theory - argues the advantages of a "large over a small republic." See THE FEDERALIST No. 10, at 83 (James Madison) (Clinton Rossiter ed., 1961). "Extend the sphere," Madison counsels, and the new government will be able to "control[] the effects of faction." Id. Read for all it's worth, Federalist No. 10 does indeed suggest that the national government will be superior to the states on a whole range of issues, not merely within its limited domain. But read this way, Federalist No. 10 is anomalous; there is no question that the Founders wanted the powers of the federal government to be "few and defined." THE FEDERALIST No. 45 at 292-93 (James Madison) (Clinton Rossiter ed., 1961). Indeed, it may be that Federalist No. 10 is assigned so frequently in college political science courses precisely because its strong nationalism is more in keeping with today's governmental structure than that of the Founders. Moreover, as Larry Kramer has recently demonstrated, the evidence suggests that Madison's strong nationalist argument was either ignored or misunderstood even by his fellow delegates at the Philadelphia convention. See Larry D. Kramer, Madison's Audience, 112 HARV. L. REV. 611 (1999).

252. Of course, as a matter of political feasibility it would have been impossible in 1787 to fundamentally rearrange state institutions, even if the Philadelphia delegates had wanted to do so.

253. U.S. CONST, art. VI, $\S 1, \mathrm{cl} .2$.

254. U.S. CONST. art. I, $\S 10$. 
[A]mbitious encroachments of the federal government on the authority of the State governments would not excite the opposition of a single State, or of a few States only. They would be signals of general alarm. Every government would espouse the common cause. A correspondence would be opened. Plans of resistance would be concerted. One spirit would animate and conduct the whole. ${ }^{255}$

. The ultimate act of "resistance," described by Madison in the passage quoted earlier, would be for the states' militias to take up arms against the federal army - a conflict, Madison assures his audience, in which the states would surely prevail. ${ }^{256}$ Notice that in these passages Madison unquestioningly assumes that the federal government would be the wrongful aggressor, and the states the defenders of liberty. For Madison and his generation, the militia were part and parcel of the federalist structure of checks and balances.

The Reconstruction Republicans' view was wholly different. To the men who framed and ratified the Fourteenth Amendment, it was manifestly the states, not the federal government, that had perpetrated the most horrible deprivations of liberty in the nation's history. The Fourteenth Amendment engrafted this new perspective onto the Constitution. While the original Bill of Rights begins with the words "Congress shall make no law," the framers of the Fourteenth Amendment began its key sentence with: "No State shall...." No longer would the states be free from constitutional restriction. This language announced a decisive shift toward a constitutional regime deeply skeptical of state power.

This skepticism certainly extended to the militia. In the Republicans' experience, state "resistance" to federal authority had been in service of the evil of slavery, not in defense of freedom. Federalist No. 46 could not have been written in the aftermath of the Civil War. Or rather, had the Republicans rewritten it, their purpose would have been to assure their audience not that the state militia would be able to fend off federal overreaching, but that in the Re-United States, the federal government would be able to guarantee a bedrock minimum of individual rights throughout the country.

In sum, then, the text, legislative history and structural implications of the Fourteenth Amendment all support the holding of the Selective Draft Law Cases. In 1815, a federal draft would have violated constitutional protections for state-based militia. By 1918, the draft was constitutional because the Fourteenth Amendment had tacitly repealed those protections. ${ }^{257}$

255. The Federalist No. 46 at 298 (James Madison) (Clinton Rossiter ed., 1961).

256. See supra text accompanying note 63.

257. The 1990 case Perpich v. Dep't of Defense, 496 U.S. 334 (1990), illustrates this tacit repeal even more clearly than do the Selective Draft Law Cases. In Perpich, the Supreme Court gave the federal government plenary authority over even the training of National Guard units, despite the explicit constitutional reservation of this authority to the states. See 


\section{TOWARD A THEORY OF THE MODERN SECOND AMENDMENT}

The impact of the Fourteenth Amendment on the Second should now be clear enough. Part I portrayed the Second Amendment as a gloss on and reinforcement of the Militia Clauses of Article I; the Amendment's purpose was to protect the Founders' allocation of power between the federal army and the states' militia. Part III showed how the Fourteenth Amendment condemned that allocation. The inescapable conclusion is that the role of the Second Amendment in the modern Constitution cannot be what it was in the original Constitution. The remaining task is to identify precisely what that role should be. One possibility, of course, is no role at all. Perhaps the Second Amendment should, like the Militia Clauses, simply fade into oblivion. Indeed, the opponents of Lincoln's Conscription Act predicted just that outcome:

How can such a power [i.e., conscription] be reconciled with the provisions of the second article of the amendments to the Constitution, that "a well-regulated militia is necessary to the security of a free State?" You render that article nugatory by such legislation, and yet it is one of the amendments adopted by the First Congress ... and unless it had been well understood that this and other amendments restricting Federal power would be adopted, it is very evident from the debates in the State conventions that the Constitution would not have been ratified. This bill, in effect, nullifies that second amendment, and abandons that "security for a free State" which our fathers deemed essential. ${ }^{258}$

Modern doctrine comes quite near to making that prediction accurate. In today's world, in which the National Guard is part of the national armed forces and states maintain no other organized militia, the only practical effect of the courts' doctrine is to prohibit Congress from disarming the National Guard. It seems unlikely in the extreme that Congress will ever seek to do that. Contemporary doctrine reduces the Second Amendment to a triviality, if not a nullity.

U.S. CoNST. art. I, $\S 8$, cl. 16 ("reserving to the States respectively ... the Authority of training the Militia according to the discipline prescribed by Congress"). It is possible to read Perpich as resting on the argument that federal funding for the Guard entitles the federal government to insist on training authority, see 496 U.S. at 351-52, but just as with the Commerce Clause and the Tenth Amendment, the Court's permission of conditional spending that circumvents limits on federal authority is tantamount to abandonment of those limits. See Matthew D. Adler \& Seth F. Kreimer, The New Etiquette of Federalism: New York, Printz and Yeskey, 1998 SUP. CT. REV. 71, 102-105 (demonstrating that permitting Congress to coerce state action through conditional spending is identical to commandeering state action in violation of the Tenth Amendment); Lynn A. Baker, Conditional Federal Spending After Lopez, 95 COLUM. L. REV. 1911 (1995) (describing and criticizing Supreme Court's willingness to permit Congress to evade enumerated-powers limits on federal authority with conditional spending); $c f$. Kathleen M. Sullivan, Unconstitutional Conditions, 102 HARV. L. REV. 1415 (1989) (describing doctrine under which federal government is prohibited from evading certain constitutional restrictions through conditional spending).

258. CONG. GlOBE, 37th Cong., 3d Sess. 1365 (1863) (statement of Sen. Bayard). 
I do not think we need to go that far. The Second Amendment remains, after all, in the text of the Constitution. In showing modern doctrine to be the product of changes in the Constitution since the Founders' era, I do not mean to say that the Unorganized Militia Approach is the only interpretively legitimate choice open to modern courts. To the contrary, I do fault the courts for failing to undertake a reconstruction of the Second Amendment that would accommodate these changes. But I certainly do not fault them for refusing to read the Amendment as guaranteeing the states access to an unorganized militia, as the revisionists urge. That reading of the Amendment is now foreclosed. In replacing the Founders' Unorganized Militia Approach with the Organized Militia Approach, modern courts have at least recognized that any interpretation of the Second Amendment today must be faithful not only to the Founders' commitments but also to the very different principles of national structure reflected in the Civil War Amendments.

In this Part, I hope to lay the groundwork for a modern theory of the Second Amendment. I begin by briefly reviewing the interpretive methodology that underlies the account of the Second Amendment I have laid out so far. Interpretation, I contend must be holistic, historically sensitive and synthetic. Only this methodology gives us a satisfactory understanding of contemporary Second Amendment doctrine, and any proposals for future doctrinal development must proceed from the same methodology.

I will then consider a recent and powerful effort to apply this methodology to the Second Amendment: Akhil Amar's argument that the Fourteenth Amendment established a strong individual right to gun ownership. In criticizing this argument, I uncover an additional interpretive constraint faced by a modern reader of the Second Amendment. In addition to the Fourteenth Amendment, a contemporary interpreter of the Second Amendment must take account of the mammoth changes in constitutional law effected during the New Deal period. Professor Amar's reading of the Amendment, which follows from his broader vision of the Bill of Rights, is unsatisfactory because it fails to appreciate the roots of modern Bill of Rights doctrine in the New Deal watershed.

\section{A. The Need for Synthesis}

I have tried thus far to dispel the "embarrassment" described by Professor Levinson. For Levinson and the other revisionists, the virtual disappearance of the Second Amendment from modern constitutional jurisprudence is a mystery, but it turns out there is a rational explanation after all. Modern courts' Organized Militia Approach is perfectly consistent with a commitment to "original intent" as the guiding principle of constitutional adjudication - as long, that is, as 
we have a suitably sophisticated methodology for interpreting and applying "original intent."

First, interpretation must be holistic. The example of the revisionists' Libertarian Approach shows the need for holism. That approach fails because it is clause-bound; it tries to divine the meaning of "right of the people to keep and bear Arms" as if the phrase could be divorced from its context among the Constitution's other military provisions.

Next, interpretation must be historically sensitive. One component of historical sensitivity is suggested by Professor Lessig in his account of interpretation-as-translation. The example of the revisionists' Unorganized Militia Approach shows the need for translation. That approach fails because it wrongly assumes that maintaining doctrinal consistency over time will automatically achieve fidelity to the Founders' intentions.

Yet, as we saw in Part II, "translation" has significant limitations. Even the Henigan-Ehrman defense of the courts, which is holistic and does attempt translation, still fails to justify modern Second Amendment doctrine as an act of fidelity to the Founders' intent. Now we can see why: Henigan and Ehrman fail to appreciate how the Second Amendment has been affected by the Fourteenth. To put the point more generally: It is not enough to account for changes in factual "presuppositions" that may affect our reading of a particular constitutional provision - we must also consider changes in other parts of the Constitution that may revise or negate the substantive commitments underlying that provision.

This follows directly from our commitment to holism. The task required is not "translation" (or not just "translation") but rather (or also) what Bruce Ackerman calls "synthesis": constructing a coherent constitutional jurisprudence out of two or more fragmentary and inconsistent "original intents." ${ }^{\text {"259 }}$ In Lessig's terminology, some changes in the context of a constitutional provision are not changes in "presuppositions," but changes in the text to be translated - or rather, new chunks of text that must be synthesized with the original text to create an intelligible new whole.

In the case of the Second Amendment, it is not enough to understand - or even to translate - what the Founders of 1787-1791 sought to accomplish. Nor is it sufficient alone to understand the aims of the Reconstruction Republicans or their purposes in drafting the Fourteenth Amendment. In addition, keeping all these things in mind, a judge must painstakingly assess which parts of the Founders' constitutional structure must be abandoned, or reconceived, in order to maintain the integrity of the whole. Understanding the courts' treat-

259. ACKERMAN, FOUNDATIONS, supra note 25 , at 86-94. 
ment of the Second Amendment is impossible without appreciating this synthetic dimension of contemporary doctrine.

\section{B. Why the Revisionists' Theory of Second Amendment "Incorporation" is Incomplete}

Of course, it is possible to accept the claim that interpretation must be holistic, historical and synthetic, and still believe that modern courts have gotten the Second Amendment all wrong. Akhil Amar has recently put forward just this argument. ${ }^{260}$ Using the methodology I advocate, Amar reaches conclusions precisely opposite those I have drawn. For Amar, the effect of the Fourteenth Amendment was not to undercut the Second, but rather to reaffirm (or perhaps reframe and extend) the constitutional commitment to the individual liberties protected by the Bill of Rights - including the "right of the people to keep and bear Arms." The result is a new strand of the revisionist argument which grounds an individual right to bear arms on the Fourteenth Amendment rather than (or more precisely, in conjunction with) the Second.

Amar's claims about the Second Amendment are part of his larger argument about the "incorporation" of the Bill of Rights. After all, the problem of synthesizing the Second Amendment with the Fourteenth is really a subset of a much larger question: What impact did the Fourteenth Amendment have on the Bill of Rights? And that question is hardly a fresh one. It was the focus of one of the central doctrinal disputes in modern constitutional law: the debate over "incorporation" of the Bill of Rights. In a series of opinions in the 1940s and 1950s, Justice Black argued that "one of the chief objects that ... [the Fourteenth Amendment was] intended to accomplish was to make the Bill of Rights applicable, to the states."261 Justice Frankfurter, while agreeing that the Fourteenth Amendment imposed significant restrictions on state governments, rejected the notion that the Amendment "was a covert way of imposing upon the States all the rules which it seemed important to Eighteenth Century statesmen to write into the Federal Amendments [i.e., the Bill of Rights]. . ."262 Frankfurter instead argued that the scope of the Fourteenth Amendment's protections were defined by concepts of "natural law"263 and "canons of decency and fairness. ..."

260. See AMAR, supra note 9, at 257-66; see also HALBROOK, supra note 111.

261. Adamson v. California, 332 U.S. 46, 71-72 (1947) (Black, J., dissenting).

262. Id. at 63-64 (Frankfurter, J., concurring).

263. Id. at 65 (Frankfurter, J., concurring) ("In the history of thought 'natural law' has a much longer and much better founded meaning and justification than such subjective.selection of the first eight Amendments for incorporation into the Fourteenth.")

264. Id. at 67 (Frankfurter, J., concurring). 
This debate was resolved in the 1960s when the Court settled on a doctrine of "selective incorporation." 265 Under this approach, most of the original Bill of Rights has been applied to the states as well as to the federal government. Moreover, at the same time the Court "incorporated" provisions of the Bill of Rights into the Fourteenth Amendment, it also expanded the substantive scope of these rights. Whether or not the process of incorporation caused these expansions, the two developments at least appear correlated. Thus the natural assumption of anyone who has the slightest familiarity with constitutional law will be that if the Fourteenth Amendment has any impact on the Second Amendment, it should be read to broaden, not narrow, the right to "keep and bear Arms."

\section{The Incorporation Conundrum}

As we have seen, however, the courts have not taken this view. In the first place, the Second Amendment is one of the few Bill of Rights provisions ${ }^{266}$ that has never been "incorporated." This fact has been something of an embarrassment for the revisionists - if the right to keep and bear arms is so fundamental, why has the Supreme Court never applied it against the states? The revisionists sometimes try to avoid this embarrassment by suggesting that the question of incorporation is still open, because the Supreme Court cases expressly refusing to apply the Second Amendment to the states date from before the inception of modern incorporation doctrine. ${ }^{267}$ But lower federal courts have consistently held that the Second Amendment is not "incorporated,"268 and the Supreme Court has twice in recent years declined to review this question. ${ }^{269}$

Of course, it may be that the courts are simply wrong, and that is Amar's contention. Amar agrees with Black that the framers of the Fourteenth Amendment sought to apply to the states at least some of the specific guarantees of the Bill of Rights, but he offers penetrating

265. Or as I would put it, "selective incorporation plus" - for what the Court took away by preferring selective incorporation to Frankfurter's "natural rights" approach, it gave back with its "right to privacy" jurisprudence. See Griswold v. Connecticut, 381 U.S. 479 (1965).

266. The others are the Seventh Amendment and the grand jury provisions of the Fifth Amendment (along with the "structural" provisions of the Ninth and Tenth Amendments and of course the all-but-obsolete Third Amendment).

267. See, e.g., Kopel, supra note 3. The cases are Presser v. Illinois, 116 U.S. 252 (1886), and United States v. Cruikshank, 92 U.S. 542 (1875).

268. See, e.g., Peoples Rights Org. v. City of Columbus, 152 F.3d 522, 538 n.18 (6th Cir. 1998); Quilici v. Village of Morton Grove, 695 F.2d 261, 270-71 (7th Cir. 1982), cert. denied, 464 U.S. 863 (1983).

269. Burton v. Sills, 248 A.2d 521 (N.J. 1968), appeal dismissed 394 U.S. 812 (1969); Quilici v. Village of Morton Grove, 695 F.2d 261 (7th Cir. 1982), cert. denied, 464 U.S. 863 (1983). 
critiques of both Black's "total incorporation" theory and the dominant "selective incorporation" doctrine. In their places, Amar presents a theory of what he calls "refined incorporation." He distinguishes between provisions protecting "a personal privilege - that is, a private right - of individual citizens" (these merit incorporation) and provisions declaring "rights of states or the public at large" (these do not). ${ }^{270}$ While acknowledging that the Second Amendment "marbled together" both private and public rights, Amar contends that at least some part of the right to bear arms is "private." $271 \mathrm{He}$ maintains that this private aspect of the right - consisting chiefly of an individual's right to own guns for the purpose of self-defense - was reaffirmed by the Fourteenth Amendment and therefore merits incorporation. ${ }^{272}$

For most of the Bill of Rights, Amar's theory of "refined incorporation" yields results that track the modern Court's case law fairly closely. It is easy, then, to read Amar as providing a new rationale for existing doctrine, and as arguing that the doctrinal changes he suggests, including incorporation of the Second Amendment, are mandated by the fundamental principles of the doctrine itself.

In fact, Amar's justification for "refined incorporation" differs radically from the rationale that underlies modern doctrine. Amar may well be right that many among those who framed and ratified the Fourteenth Amendment believed that its Privileges and Immunities Clause would apply the Bill of Rights to the states in something like "refined incorporation." But that argument has never been accepted by the Supreme Court. To accept it now - and to change Second Amendment doctrine on that basis - would be to recant not just the "selective incorporation" case law of the past several decades, but fully 130 years of Fourteenth Amendment jurisprudence. For the incorporation cases of the 1940s and 1950s were the Court's second effort at synthesizing the Fourteenth Amendment with the original Constitution and the Bill of Rights; the first was the series of cases, culminating in Lochner v. New York, in which the Court defended common law rights to property and contract against governmental infringement. The incorporation cases cannot be understood without appreciating that they represented an effort not simply to integrate the Fourteenth Amendment with the original Constitution, but to do so in a way that avoided the substantive commitments of the by-thenrepudiated Lochner decision.

270. AMAR, supra note 9 , at 221.

271. Id. at 222.

272. Id. at 257-66. Note that Amar's new version of the revisionist argument not only shifts the foundation of the right from the Second Amendment to the Fourteenth, but it also restates the right as a libertarian one rather than a right derived from individuals' membership in an unorganized militia. 


\section{The Road to Incorporation ${ }^{273}$}

The long and winding road to incorporation began in 1873 with the Slaughter-House Cases. ${ }^{274}$ Slaughter-House involved a Louisiana statute that created a livestock-slaughtering monopoly in New Orleans. The plaintiffs in Slaughter-House, competing butchers, challenged this statute under all three of the Fourteenth Amendment's key substantive clauses, arguing that it deprived them of the privileges and immunities of plying their trade, that it deprived them of equal protection of the law by unequally apportioning the license to slaughter, and that it deprived them of liberty and property without due process of law.

As every first-year constitutional law student knows, SlaughterHouse took an extremely narrow view of the Fourteenth Amendment. Writing for the Court, Justice Miller concluded that the "one pervading purpose" of the Amendment was "the freedom of the slave race." 275 The butchers' claims, having nothing to do with this purpose, were easily dismissed.

Now, most first-year constitutional law students also learn that Miller's narrow reading of the Privileges and Immunities Clause was wrong, and terribly unfortunate (at least that's what I learned). ${ }^{276}$ Miller wrote for a bare five-to-four majority in Slaughter-House, and the dissenters vigorously argued for a more sweeping view of the Amendment, one which would protect "the natural and inalienable rights which belong to all citizens." ${ }^{277}$ Amar sees the Court's eventual incorporation of the Bill of Rights into the Fourteenth Amendment as a vindication of the dissenters' position.

In fact, however, there were two major - and importantly different - dissenting opinions in Slaughter-House. Amar focuses his discussion mostly on Justice Bradley's dissent, which he reads as anticipating modern incorporation doctrine. I quibble with this reading, ${ }^{278}$

273. The following account of the progression from Slaughter-House to Lochner borrows from David Yassky, Eras of the First Amendment, 91 CoLUM. L. REV. 1699, 1724-28 (1991).

274. 83 U.S. (16 Wall.) 36 (1873).

275. Id. at 71 .

276. It is standard for constitutional law scholars to bemoan the Slaughter-House Cases - how much better it would have been if later individual rights jurisprudence (Roe, Griswold, etc.) had been able to develop on the sturdy foundation of the Privileges and Immunities Clause rather than the rickety Due Process Clause. See Kevin Christopher Newsom, Setting Incorporationism Straight: A Reinterpretation of the Slaughter-House Cases, 109 YALE L.J. 643, 647 \& n.13 (2000) (listing scholarly works criticizing the Slaughter-House Cases). The Court's recent decision in Saenz v. Roe, 526 U.S. 489 (1999), which hints at a revival of the Privileges and Immunities doctrine, will only add fuel to this fire.

277. Slaughter-House Cases, 83 U.S. at 96 (Field, J., dissenting).

278. It is true that Bradley does list several Bill of Rights guarantees - "the right of trial by jury, or free exercise of religious worship, the right of free speech and a free press, the right peaceably to assemble for the discussion of public measures, the right to be secure 
but even if we see Bradley as a proto-incorporationist, the Court never followed his lead. Rather, it was the other Slaughter-House dissent that of Justice Field - which the Court eventually elevated into doctrine.

Like Bradley, Field saw the Miller interpretation of the Fourteenth Amendment as far too narrow. But unlike Bradley, Field did not view the Amendment as an invitation to formulate judicially-created fundamental rights. Rather, the "privileges and immunities" he believed the Amendment to protect were the liberties of property and contract enjoyed under the common law. ${ }^{279}$ Thus, for Field the crucial fact in the case was that the Louisiana slaughterhouse statute established a monopoly, and that "monopolies in any known trade or manufacture ... were held void at common law in the great Case of Monopolies." ${ }^{280}$ Field elaborated his view in another case involving the same Louisiana statute:

All grants of this kind are void at common law, because they destroy the freedom of trade, discourage labor and industry, restrain persons from getting an honest livelihood, and put it in the power of the grantees to enhance the price of commodities. They are void because they interfere with the liberty of the individual to pursue a lawful trade or employment. ${ }^{281}$

In 1873 , both Bradley and Field were too radical for a majority of the Justices. To Miller, the dissenters threatened to "fetter and degrade the State governments," 282 to federalize "the entire domain of

against unreasonable searches and seizures" - among those protected by the Privileges and Immunities Clause. Id. at 118 (Bradley, J., dissenting). But Bradley's vision of the Fourteenth Amendment went well beyond mere incorporation of the Bill of Rights. He saw the Amendment as protecting "privileges and immunities which are, in their nature, fundamental; which belong, of right, to the citizens of all free governments." Id. at 117 (Bradley, J., dissenting) (quoting Corfield v. Coryell). In elaborating the content of these fundamental rights, Bradley looked to the Bill of Rights, but also to the Magna Carta and the "constitutional history of England." Id. at 118 (Bradley, J., dissenting). Indeed, for Bradley the existence of these rights did not depend on the Constitution at all; he wrote that "even if the Constitution were silent, the fundamental privileges and immunities of citizens, as such, would be no less real and no less inviolable than they now are." Id. at 119. The importance of the Fourteenth Amendment was not that it specified the "privileges and immunities" of citizens, but that it authorized the Supreme Court to order redress when those privileges and immunities were violated. In Bradley's view, then, the only limits to the Court's new ability to impose restrictions on state governments came from the Court's own understanding of what rights were "fundamental" in Anglo-American tradition.

279. See Yassky, supra note 273 , at $1726-28$. Kevin Newsom has recently buttressed this argument with valuable evidence showing that Field's repeated references to the Fourteenth Amendment as protecting "common rights" expressed his view that the Amendment protected common law rights to property and contract. See Newsom, supra note 276, at 658-63.

280. 83 U.S. at 101-02 (Field, J., dissenting) (citing Case of Monopolies, 11 Coke's Reports 85 (K.B. 1602)).

281. Butchers' Union Slaughter-House and Live-Stock Landing Co. v. Crescent City Live-Stock Landing and Slaughter-House Co., 111 U.S. 746, 755-56 (1884) (Field, J., concurring) (emphasis added).

282. 83 U.S. at 78. 
civil rights heretofore belonging exclusively to the States." ${ }^{283}$ This was simply too "great a departure from the structure and spirit of our institutions." 284

But in time, the seeds planted by Field in Slaughter-House flowered. In the 1897 case Allgeyer $v$. Louisiana ${ }^{285}$ the Court struck down a Louisiana statute regulating sellers of insurance, establishing the right to contract as a first-order constitutional guarantee. The Court's opinion, authored by Justice Peckham, built its key holding on the doctrinal foundation laid by Field:

The liberty mentioned in [the Fourteenth] [A]mendment means not only the right of the citizen to be free from the mere physical restraint of his person ... but the term is deemed to embrace the right of the citizen to be free in the enjoyment of all his faculties; to be free to use them in all lawful ways; to live and work where he will; to earn his livelihood by any lawful calling; to pursue any livelihood or avocation, and for that purpose to enter into all contracts which may be proper, necessary and essential to his carrying out to a successful conclusion the purposes above mentioned. ${ }^{286}$

The crucial qualifiers used by Peckham - "all lawful ways" and "any lawful calling" - incorporated the Slaughter-House/Butchers' Union premise that the common law defined the extent and nature of liberties protected by the Constitution from legislative interference. Peckham's opinion ten years later in Lochner became the canonical statement of this position. By according constitutional protection to the common law right to sell labor, Lochner completed the reversal of Slaughter-House and the vindication of Justice Field's dissent. ${ }^{287}$

I have argued elsewhere that Field's and Peckham's synthesis of the Fourteenth Amendment with the original Constitution and the Bill of Rights was - at the time - a commendable effort at constitutional interpretation, deeply grounded in constitutional structure. ${ }^{288}$ For now, let me make two quick points. First, there is some evidence that the framers of the Fourteenth Amendment intended the Privileges and Immunities Clause to function as Field believed it should ${ }^{289}-$ al-

283. Id. at $77-78$.

284. Id. at 78 .

285. 165 U.S. 578 (1897).

286. Id. at 589.

287. See Lochner v. New York, 198 U.S. 45 (1905).

288. See Yassky, supra note 273, at 1721-24.

289. The argument, in short, is that the framers of the Fourteenth Amendment maintained a sharp distinction between civil rights (meaning the right to be treated as a person for purposes of property ownership, contract formation and protection against torts) and political rights (such as the right of free speech, the right to serve on a jury and the right to serve in the militia), and they saw the Fourteenth Amendment as protecting, primarily if not exclusively, the former. See, e.g., Cong. GloBE, 39th Cong., 1st Sess. 472, 476 (1866) (statement of Sen. Trumbull) (stating that purpose of Civil Rights Act, on which Fourteenth 
though I freely concede that the evidence marshalled by Amar in support of the incorporationist interpretation is impressive.

Second, and more important for our purposes, it is inarguable that in the decades following ratification of the Fourteenth Amendment, the Court did in fact understand the Amendment's liberty protections in the terms set forth in Lochner. During that period - the period when the Court was closest to the work of John Bingham and the other Reconstruction Republicans - the Court saw the Fourteenth Amendment as incorporating not "the specific guarantees of the Bill of Rights," $" 290$ but rather common law rights to property and contractual freedom.

That understanding persisted until the repudiation of Lochner in the late 1930s. West Coast Hotel v. Parrish ${ }^{291}$ obliterated the doctrine that individuals had substantive economic rights grounded in the Due Process clause. In doing so, West Coast Hotel left a void: If the Fourteenth Amendment did not guarantee common law rights to property and contract, then what did it accomplish? The Court's answer was to reinvigorate the Bill of Rights and to apply its provisions to the states. It is no accident that it was only after West Coast Hotel that the incorporation debate exploded within the Court. ${ }^{292}$

Amendment was based, was to protect "the right to make and enforce contracts, to sue and be sued, and to give evidence, to inherit, purchase, sell, lease, hold and convey real and personal property, and to full and equal benefit to all laws and proceedings for the security of person and property"); see also RAOUL BERGER, GOVERNMENT BY JUDICIARY (1977); RAOUL BERGER, THE FOURTEENTH AMENDMENT AND THE BILL OF RIGHTS (1989).

290. Adamson v. California, 332 U.S. 46, 83 (Black, J., dissenting).

291. 300 U.S. 379 (1937).

292. The Court's decision in Chicago, Burlington and Quincy Railroad v. Chicago, 166 U.S. 226 (1897), is sometimes said to be the first incorporation decision. See, e.g., Levinson, supra note 3, at 653 . That is a misreading of the case. The defendant in the case, the City of Chicago, had condemned property belonging to the plaintiff railroad; the railroad alleged that it had received insufficient compensation. The Court held that it would violate the Fourteenth Amendment if "private property is taken for the State ... without compensation," Chicago, Burlington and Quincy Railroad, 166 U.S. at 241, although it found no violation in the case before it. The Court's declaration is sometimes thought to be an "incorporation" of the Fifth Amendment's Just Compensation Clause, but the Court's opinion never mentions the Fifth Amendment. Instead, the Court sees its holding as a straightforward application of the Fourteenth Amendment's own Due Process Clause. If the case implies anything about the Fifth Amendment, it is that the Just Compensation Clause is unnecessary, as the obligation to provide compensation inheres in the due process requirement. Rather than an early effort at incorporation, Chicago, Burlington and Quincy Railroad should be seen as emblematic of the property-centric Lochner era, as Justice Black suggested in his Adamson dissent, see 332 U.S. at 79-80.

It is true, however, that the Court began to apply the First Amendment against the states several years prior to West Coast Hotel. See Gitlow v. New York, 268 U.S. 652 (1925); Stromberg v. California, 283 U.S. 359 (1931) (invalidating state criminal syndicalism statute); Near v. Minnesota ex rel. Olson, 283 U.S. 697 (1931) (invalidating state statute authorizing injunctions against defamatory newspapers); Grosjean v. American Press Co., 297 U.S. 233 (1936) (striking down special tax on newspapers); De Jonge v. Oregon, 299 U.S. 353 (1937) (overturning state conviction under anti-Communist censorship statutes). In these cases, the Court moved from "assum[ing]" arguendo that "freedom of speech ... [is] protected by the 
In effect, West Coast Hotel put before the Court the same question it had originally faced in the Slaughter-House Cases: Given that the Fourteenth Amendment was intended to protect certain basic rights against invasion even by the states, precisely what are those rights? The only difference was that this time the path taken by Justice Field and the Lochner Court was foreclosed. West Coast Hotel thus challenged the Court to develop a "due process" jurisprudence that not only built on the foundation of the original Constitution and the Bill of Rights, and not only incorporated the watershed changes of the Fourteenth Amendment, but also accommodated the newly-legitimate activist state. The debate between Frankfurter's "natural law" approach and Black's "total incorporation" approach was a response to this challenge. ${ }^{293}$ In United States $v$. Carolene Products, ${ }^{294}$ one of the early, crucial departures from Lochner, the Court gave a hint of what was to come. Justice Stone's famous footnote four observed that the Court's repudiation of constitutionalized economic rights did not mean the end of meaningful judicial review; rather, Stone declared, the Court would thenceforward be particularly careful to ensure compliance with the "specific prohibition[s] of the Constitution, such as those of the first ten amendments."295

The link between West Coast Hotel and the incorporation debate is evident in Justice Black's most significant statement of his position, his dissent in Adamson v. California. ${ }^{296}$ Black saw clearly that the FieldPeckham approach to the Fourteenth Amendment had stood in the way of the incorporationist approach he favored. Referring to a key anti-incorporation decision, Twining $v$. New Jersey, ${ }^{297}$ Black wrote: "At the same time that the Twining decision held that the states need not conform to the specific provisions of the Bill of Rights, it consolidated the power that the Court had assumed under the due process clause by laying even broader foundations for the Court to invalidate state and

due process clause of the Fourteenth Amendment", Gitlow, 268 U.S. at 666, to declaring that "[i]t is no longer open to doubt," Near, 283 U.S. at 707. The shift, however, was accompanied by virtually no analysis. The Court's sustained inquiry into the incorporation question did not occur until the 1940s. Accordingly, I read these cases as the sort of deviation from a dominant paradigm that opens the way for a later shift in the paradigm - without which, they would have remained anomalous and would likely have been narrowed or abandoned by subsequent Courts. See generally THOMAS S. KUHN, THE STRUCTURE OF SCIENTIFIC REVOLUTIONS (1962).

293. This debate paralleled in many ways the debate between the Slaughter-House dissenters - with Frankfurter articulating the modern version of Bradley's "natural law" approach and Black arguing for doctrine constrained, not by the common law as in Field's view, but by the text of the Bill of Rights.

294. 304 U.S. 144 (1938).

295. Id. at 152 n.4.

296. 332 U.S. 46, 68-123 (1947) (Black, J., dissenting).

297. 211 U.S. $78(1908)$. 
even federal regulatory legislation [citing Lochner]." ${ }^{298}$ Black believed the Field-Peckham approach was wrong even when decided - "Neither the contraction of the Bill of Rights safeguards [i.e., the refusal to incorporate] nor the invalidation of regulatory laws ... would readily be classified as the most satisfactory contribution of this Court to the nation" 299 - but for our purposes, the key point is that it was West Coast Hotel that opened the door to modern incorporation doctrine.

With this skeletal history of incorporation, I want to suggest that Amar jumps too hastily from his historical research into the Fourteenth Amendment to his doctrinal conclusions about incorporation. Perhaps it is true that John Bingham, his colleagues in Congress and the state ratifiers meant to "refine" the Bill of Rights as well as to apply the refined Bill against the states. But even if so, it must be said that from the period immediately following ratification of the Fourteenth Amendment until the 1940s, the Supreme Court rejected that claim. And when the Court did begin in earnest to implement Bingham's (putative) vision, it did so in response to yet another set of massive changes in constitutional structure - namely, the New Deal legitimation of an activist, bureaucratized, national government. Amar's account of incorporation explains neither of these phenomena - not the absence of incorporation doctrine before the New Deal, nor its emergence after. Thus Amar's theory is far more radical than it may first appear - it is not so much an explanation of the Court's Bill of Rights doctrine as an effort to replace it.

For some, that observation will not be a fatal criticism - and maybe not a criticism at all. Perhaps Amar's vision of the postFourteenth Amendment Bill of Rights is clearer than the Court's. I do not want to take on so large a question here. My narrower focus is on Amar's particular Second Amendment claim - the claim that the Fourteenth Amendment not only applies the Second Amendment to the states, but also somehow intensifies whatever "individual" right to keep and bear arms was contained within the original Second Amendment. My point is simply that Amar cannot support this claim by arguing that the Second Amendment is an anomaly in contemporary constitutional law. Again, it is easy to read Amar as arguing that the Supreme Court has basically gotten incorporation right, but that in a few areas - notably the Second Amendment - it has gone astray. If the Court has been "refining" the other Bill of Rights Amendments, the argument would be, then it should do so with the Second as well. This argument would be very appealing if Amar's overall theory of "refined incorporation" matched the case law. But it does not. In seeking to refine an "individual right" from the Second Amendment's

298. Adamson, 332 U.S. at 82.

299. Id. at 83 . 
militia-focused ore, Amar is challenging the Court's view not only of the Second Amendment, but of the entire Bill of Rights.

\section{Synthesizing the New Deal: The First and Second Amendments Compared}

Let me return, then, to other revisionists who do in fact make the Second-Amendment-as-anomaly claim. It is a recurring theme in the revisionist corpus that current doctrine treats the Second Amendment so unlike other Bill of Rights provisions. ${ }^{300}$ Rights to free speech and to freedom from unreasonable searches are recognized as fundamental individual rights; they are zealously protected by the courts and celebrated by scholars - so why does their textual neighbor, the right to bear arms, get nothing but disrespect?

The revisionists' descriptive point is certainly well taken. There is something singular about the neglect of the Second Amendment by contemporary courts and scholars. There is a difference between the courts' generous readings of the First, Fourth, Fifth and Sixth Amendments and their much more crabbed reading of the Second Amendment.

But this observation has normative bite only if we believe the Second Amendment should be interpreted "comparably" to other Bill of Rights Amendments. To the clause-bound originalist - and most revisionists, with the obvious exception of Amar, fall into this camp this premise of comparability can be taken for granted. But our attention to holism, change and synthesis tells us that amendments ratified at the same time can be affected very differently by changes in constitutional structure since that time. And as we have just seen in our review of Akhil Amar's theory, the Court's interpretation of the Bill of Rights has been affected not just by the Fourteenth Amendment, but by the New Deal as well.

In this Section, then, I want to suggest that modern courts' disparate treatment of the Second Amendment (compared to other Bill of Rights provisions) is due to the impact of the New Deal - that synthesizing the New Deal into the Constitution yielded different results for the Second Amendment than for other Bill of Rights provisions.

To defend this claim, I need to provide a full account of the interplay among the Bill of Rights, the Fourteenth Amendment and the New Deal changes. I wish I could do so - indeed, I hope at another time to be able to do so - but much of the work necessary to provide such an account remains to be done. Let me start down the road, however, by very briefly contrasting the development of the Second

300. See, e.g., Levinson, supra note 3, at 657-58, Powe, Jr., supra note 3; Van Alstyne, supra note 3 , at $1239-41$. 
Amendment with that of the First - in particular, that amendment's guarantee of "freedom of speech."

Like the Second Amendment, the First shared the federalist premises of the original Constitution. It aimed to keep the federal government out of the business of censorship, while leaving the states a free hand to regulate speech as they pleased. At one level this reflected the Founders' general inclination to trust the states, rather than the federal government, with sensitive matters (recall the debate in the First Congress over Madison's proposed "conscientious objector" provision $^{301}$ ). Most important, as Madison described in Federalist No. 46, both dissent by state government officials (protected under the First Amendment) and the ultimate threat of resistance by state militias (protected under the Second) would act as crucial checks on federal overreaching. ${ }^{302}$

The parallels continued throughout the post-Civil War period, with both the evisceration of the Constitution's military provisions and a dramatic reduction in the scope of First Amendment protection, although these trends had different specific causes.

With the Second Amendment and the Militia Clauses, Lincoln's nationalization of the military meant obsolescence. The decline of free speech, by contrast, was a byproduct of the Supreme Court's Lochner jurisprudence. The Court's reconceptualization of liberty rights in the common law terms of property and contract left speech rights unprotected. The common law was not concerned with free speech - indeed, the common law permitted prior restraints on publication and libel suits based on criticism of public officials. Accordingly, speech rights hit their nadir in the decades following the Civil War. Not only did state governments continue actively to censor dissidents, but the federal government got into the act as well, using seditious libel prosecutions to imprison, if not to silence, critics of the government. ${ }^{303} \mathrm{At}$ the same time, as we have seen, the Court in the Selective Draft Law Cases was putting its imprimatur on the death of the Founders' military system.

But here the comparison ends. Free speech rights exploded in the 1930s and 1940s. As the Supreme Court began to work through the constitutional implications of the New Deal, it issued a series of lode-

301. See supra text accompanying notes 78-80.

302. See supra text accompanying notes $63,255,256$.

303. In 1919, for example, the Supreme Court upheld a federal judge's decision to sentence Eugene Debs to ten years in prison for giving a speech against American involvement in World War I. See Debs v. United States, 249 U.S. 211 (1919). While serving his sentence, Debs received nearly one million votes as the Socialist Party candidate in the 1920 presidential election. INFORMATION PLEASE ALMANAC 614 (41st ed. 1988). See also, e.g., Whitney v. California, 274 U.S. 357 (1927); Gitlow v. New York, 268 U.S. 652 (1925) (upholding state conviction for "criminal syndicalism"); Rabban, The First Amendment in Its Forgotten Years, 90 YALE L.J. 514 (1981); Yassky, supra note 273, at 1717-20. 
star opinions establishing the basic framework of the robust free speech regime that has persisted to this day: Lovell v. City of Griffin (1938) ${ }^{304}$ Hague v. CIO (1939), ${ }^{305}$ West Virginia State Board of Education v. Barnette (1943), ${ }^{306}$ and Marsh v. Alabama (1946). ${ }^{307}$ Over the next few decades the Court would continue to elaborate this framework, ${ }^{308}$ and would dramatically expand the rights protected by the Fourth ${ }^{309}$ Fifth ${ }^{310}{ }^{3 i x t h}{ }^{311}$ and Eighth ${ }^{312}$ Amendments as well - thus fulfilling the promise of Carolene Products.

Yet throughout all this, the Second Amendment has remained a virtual nullity. The Supreme Court's lone major Second Amendment case, United States v. Miller, ${ }^{313}$ was decided in 1939 - a year after Carolene Products, and in the midst of the First Amendment's rebirth. Miller involved a prosecution under the National Firearms Act of 1934. ${ }^{314}$ This statute, the first federal gun control law, regulated the possession of machineguns and short-barreled shotguns by requiring anyone possessing such a gun to obtain a license from the Treasury Department. Because the licensing process was rigorous and license applicants were required to pay a hefty fee, the effect was a near ban on the private possession of these weapons. As we have seen, a comparable statute enacted in 1800 would surely have been struck down, but the Miller Court upheld the law, explicitly rejecting a Second

304. 303 U.S. 444 (1938) (striking down municipal ordinance prohibiting the distribution of handbills without a permit). phlets).

305. 307 U.S. 496 (1939) (enjoining municipality from prohibiting distribution of pam-

306. 319 U.S. 624 (1943) (forbidding public schools to require students to recite pledge of allegiance).

307. 326 U.S. 501 (1946) (establishing right to distribute pamphlets on private property in "company town"); see also De Jonge v. Oregon, 299 U.S. 353 (1937) (over-turning state conviction under anti-Communist censorship statutes); Grosjean v. American Press Co., 297 U.S. 233 (1936) (striking down special tax on newspapers); Stromberg v. California, 283 U.S. 359 (1931) (invalidating state criminal syndicalism statute); Near v. Minnesota ex rel. Olson, 283 U.S. 697 (1931) (invalidating state statute authorizing injunctions against defamatory newspapers). On the timing of these opinions, see supra note 113; see also Yassky, supra note 106.

308. See, e.g., Brandenburg v. Ohio, 395 U.S. 444, 447 (1969) (stating that subversive advocacy is protected "except where [it] is directed to inciting or producing imminent lawless action and is likely to incite or produce such action"); New York Times Co. v. Sullivan, 376 U.S. 254, $279-83$ (1964) (establishing "actual malice" test for libel of public figure).

309. See, e.g., Terry v. Ohio, 392 U.S. 1 (1968); Mapp v. Ohio, 367 U.S. 643 (1961). (1964).

310. See, e.g., Griffin v. California, 380 U.S. 609 (1965); Malloy v. Hogan, 378 U.S. 1

311. See, e.g., Duncan v. Louisiana, 391 U.S. 145 (1968); Pointer v. Texas, 380 U.S. 400 (1965); Gideon v. Wainwright, 372 U.S. 335 (1963).

312. See, e.g., Robinson v. California, 370 U.S. 660 (1962).

313. 307 U.S. 174 (1939).

314. Act of June 26, 1934, ch. 757, 48 Stat. 1236. 
Amendment challenge. There is some debate about the precise meaning of Miller - I will say more about this debate below ${ }^{315}$ — but at the very least, it is clear that the Miller Court avoided giving the Second Amendment a broad construction similar to that of the First. It is indisputable, moreover, that within a few years of Miller the lower courts had fleshed out their Organized Militia Approach, ${ }^{316}$ and that the Supreme Court has since repeatedly declined to review that approach. ${ }^{317}$

The mystery, then, is why the Court chose not to include the Second Amendment in its resurgent liberty jurisprudence. Without attempting to provide a full-blown explanation of the Court's synthesis of the New Deal with pre-existing amendments, let me put forward a working hypothesis: The Supreme Court of the late 1930s and 1940s saw free speech rights as both ameliorating dangers of the new administrative state, while also being rooted in key New Deal themes; accordingly, it revitalized the First Amendment. The Court could not, however, envision a similar role for the right to bear arms.

The main innovation of the New Deal was that it greatly expanded the power of government - and particularly of the federal government. In addition to overturning substantive due process constraints on economic regulation, ${ }^{318}$ the Court also eviscerated Commerce Clause $^{319}$ and separation of powers ${ }^{320}$ restraints on federal power. The

\section{See infra Section IV.C.}

316. See Cases v. United States, 131 F.2d 916 (1st Cir. 1942); United States v. Tot, 131 F.2d 261 (3rd Cir. 1942).

317. See United States v. Rybar, 103 F.3d 273 (3d Cir. 1996), cert. denied, 522 U.S. 807 (1997); Hickman v. Block, 81 F.3d 98, 101 (9th Cir. 1996), cert. denied sub nom. Hickman v. County of Los Angeles, 519 U.S. 912 (1996); Quilici v. Village of Morton Grove, 695 F.2d 261 (7th Cir. 1982), cert. denied, 464 U.S. 863 (1983); United States v. Warin, 530 F.2d 103 (6th Cir. 1976), cert. denied, 426 U.S. 948 (1976).

318. Compare West Coast Hotel Co. v. Parrish, 300 U.S. 379 (1937) (upholding state minimum wage statute) with Moorehead v. New York ex rel. Tipaldo, 298 U.S. 587 (1936) (invalidating state minimum wage statute under Due Process Clause of the Fourteenth Amendment).

319. Compare Wickard v. Filburn, 317 U.S. 111 (1942) (upholding production quotas of Agricultural Adjustment Act of 1938), and United States v. Darby, 312 U.S. 100 (1941) (upholding wage and hour requirements of Fair Labor Standards Act of 1938), and Steward Mach. Co. v. Davis, 301 U.S. 548 (1937) (upholding federal unemployment insurance system of Social Security Act of 1935), with United States v. Butler, 297 U.S. 1 (1936) (invalidating acreage reduction provisions of Agricultural Adjustment Act of 1933 as beyond scope of congressional power), and Carter v. Carter Coal Co., 298 U.S. 238 (1936) (invalidating Bituminous Coal Conservation Act as exceeding Commerce Clause power), and Hammer v. Dagenhart, 247 U.S. 251 (1918) (invalidating Child Labor Act as exceeding Commerce Clause power).

320. Compare NLRB v. Jones \& Laughlin Steel Corp., 301 U.S. 1 (1937) (upholding National Labor Relations Act of 1935), and Yakus v. United States, 321 U.S. 414 (1944), with A.L.A. Schechter Poultry Corp. v. United States, 295 U.S. 495 (1935) (invalidating National Industrial Recovery Act on separation of powers and Commerce Clause grounds). 
cumulative result was a government capable of speedy, sweeping action.

Critics, of course, saw in the new government order a grave threat to individual liberty, and even many New Deal supporters shared this concern, and both groups looked to the Court to set limits. The problem for the Court was to devise limits that would not interfere with the primary aims of the New Deal. The Court's solution was not to restrict the substantive reach of the new administrative state, but to ensure its democratic accountability. The Court saw that because the government could reorder citizens' lives so profoundly, the need for popular control of the government was all the more important. Speech rights were a prime constitutional mechanism for implementing this vision.

The Court's focus on protecting the mechanisms of democratic accountability also helped to resolve a tension within the New Deal's ideological structure. On one hand, Roosevelt's changes were made in the name of majoritarian government. On the other hand, the New Dealers prized "nonpartisan experts" and "independent administrators." And indeed, many critics - and, again, even some friends - of the New Deal believed that the new behemoth government agencies threatened to slip the bonds of majoritarian control. While the Justices' abrogation of the nondelegation doctrine exacerbated this threat, their insistence that political debate remain uncorrupted by government intervention served, in some measure, to alleviate it. Thus by developing a robust, individual right to free speech, the Court elegantly blended constitutional values from the Founding, Reconstruction and the New Deal.

The Second Amendment picture was quite different. While censorship was no part of Roosevelt's agenda, gun control - as part of crime control - was. The first of his "four freedoms" was "freedom of speech and expression" - the last was "freedom from fear," to be safeguarded by a powerful national government. ${ }^{321}$ Indeed, the National Firearms Act upheld in Miller was an important component of the New Deal program, and was touted as such in Roosevelt's political speeches. ${ }^{322}$ To be sure, the National Firearms Act was not nearly as central to Roosevelt's program as his more well known economic regulation initiatives, but the Act did fit comfortably within his new paradigm of activist central government. To the Justices deciding Miller in 1939, striking down the Act would have seemed like a return

321. See Franklin D. Roosevelt, Address Before Joint Session of Congress (Jan. 6, 1941), in NOTHING TO FEAR: THE SELECTED ADDRESSES OF FRANKLIN DELANO ROOSEVELT 1932-1945 at 258, 266 (B.D. Zevin ed. 1946).

322. See Franklin D. Roosevelt, Address to the American People (June 28, 1954), in NOTHING TO FEAR: THE SELECTED ADDRESSES OF FRANKLIN DELANO ROOSEVELT 19321945 supra note 321, at 34, 35; Franklin D. Roosevelt, Address in Chicago, IL (Oct. 14, 1936) in id. at 60, 64. 
to the ways of the Old Court. Elevating an individual property right in firearms over the power of the government to promote public welfare would have been wholly inconsistent with New Deal principles.

And if a reconceived (or as Amar would have it, "refined") individual right to own guns fit poorly with the Court's broader post-New Deal jurisprudence, reviving the traditional understanding of the Second Amendment was equally implausible. With another Great War looming, the Founders' preference for state militias over a national army must have seemed quaint to say the least.

\section{United States v. Miller and the Failure of the Courts}

This is not to say, however, that it would have been impossible or that it is impossible today - for the Court to develop a jurisprudence of the Second Amendment that respects the modern constitutional order. I am not at all sure that the Second Amendment law we have now is the best Second Amendment law we can have, even within interpretively legitimate bounds. Modern doctrine reduces the Amendment to a virtual nullity - and a constitutional amendment is a terrible thing to waste. We cannot, of course, revive the Amendment by returning to the Founders' specific conception of decentralized military structure with states playing an intermediary role. It is another question whether (or to what extent) the core values underlying this structure remain viable. How difficult should it be for the President to use military force? What mechanisms should the Court insist upon - in the name of the Constitution - to ensure that warmaking remains subject to democratic accountability?

Scholars have engaged these questions with some fascinating results. Elaine Scarry, for example, has offered a brilliantly provocative reading in which the Second Amendment prohibits the use of nuclear weapons. ${ }^{323}$ David Williams suggests that taking the Second Amendment seriously might mean reviving the universal-service militia. ${ }^{324}$ Or perhaps the Second Amendment should be read to require a draft reading the people's right to bear arms, in effect, as a nondelegable duty.

The courts, however, and most important the Supreme Court, have utterly failed to enter this discussion. We are nearly at the end of this Article, and I have said very little about the Supreme Court's opinion in Miller. The reason is that the opinion itself says very little. The defendant in the case, Jack Miller, had been prosecuted under the National Firearms Act for unlicensed possession of a short-barreled shot-

323. Elaine Scarry, War and the Social Contract: Nuclear Policy, Distribution, and the Right to Bear Arms, 139 U. PA. L. REV. 1257 (1991).

324. Williams, The Terrifying Second Amendment, supra note 3, at 607-10. 
gun, and the Court rejected Miller's Second Amendment challenge to the Act. The operative language in its opinion is this:

In the absence of any evidence tending to show that possession or use of a "shotgun having a barrel of less than eighteen inches in length" at this time has some reasonable relationship to the preservation or efficiency of a well regulated militia, we cannot say that the Second Amendment guarantees the right to keep and bear such an instrument. Certainly it is not within judicial notice that this weapon is part of the ordinary military equipment or that its use could contribute to the common defense. ${ }^{325}$

Based on this passage, the revisionists read Miller as holding merely that certain weapons are beyond the reach of Second Amendment protection. They contend that lower courts have illegitimately constructed the Organized Militia Approach by taking Miller's language about "the preservation of efficiency of a well regulated militia" out of context. ${ }^{326}$

There are problems with the revisionists' view of Miller. First, the National Firearms Act regulated not only short-barreled shotguns but also machineguns - which were standard-issue military equipment in 1939, as they are today. The Miller Court does not even mention that fact. Yet if we read Miller as resting on the premise that short-barreled shotguns are not "military equipment," the National Firearms Act's regulation of machine guns is presumably unconstitutional. True, judges are supposed to limit themselves to the case at hand, but it seems odd that the Court would have upheld one part of a statute by formulating a rule that immediately and obviously invalidates another part of the very same statute without even alluding to the tension.

Second, the revisionist reading of Miller has the perverse result that the deadlier a firearm is, the more likely it is to receive constitutional protection - because the military, of course, prefers weapons that are as efficient and effective at killing as possible. Or as the First Circuit put it in a case decided a few years after Miller: "Another objection [to this reading of Miller] ... is that according to it Congress would be prevented by the Second Amendment from regulating the possession or use by private persons ... of distinctly military arms, such as machine guns, trench mortars, anti-tank or anti-aircraft guns ....",327

Moreover, the Miller opinion does plainly rule out the revisionists' Libertarian Approach. If the Second Amendment is truly about a per-

325. 307 U.S. at 178 (quoting the statute).

326. See, e.g., Brannon P. Denning, Can the Simple Cite Be Trusted?: Lower Court Interpretations of United States v. Miller and the Second Amendment, 26 CUMB. L. REV. 961 (1996); Nelson Lund, The Past and Future of the Individual's Right to Arms, 31 GA. L. REV. 1, 40-41 n.96 (1996); L.A. Powe, Jr., Guns, Words and Constitutional Interpretation, 38 WM. \& MARY L. REV. 1311, 1332 (1997).

327. Cases v. United States, 131 F.2d 916, 922 (1st Cir. 1942). 
sonal right to arm oneself, then the question whether there is any link between the regulated weapon and militia service, the question at the crux of Miller, is irrelevant. A sawed-off shotgun is quite useful for self-defense - it is, in fact, a terrifying weapon - and under the Libertarian Approach, denying access to such a weapon would certainly infringe upon a protected Second Amendment interest. ${ }^{328}$

These are all good reasons to reject the revisionsts' reading of Miller. But I believe the most important reason courts have read Miller the way they have is because they sense the importance of the changes in constitutional structure that I have tried to examine in this Article. The Organized Militia Approach should be seen as an effort to understand the "right to keep and bear Arms" in light of the Fourteenth Amendment's radical shift of power - including military power - from the states to the federal government. The Founders designed the Constitution in the belief that state militias were preferable to a federal army; after the Civil War, this belief could no longer serve as a fundamental constitutional premise. By the time Miller reached the Court, it had been twenty years since the Selective Draft Law Cases approved a federal draft, confirming the repudiation of Article I's protections for the militia. The purpose of the Second Amendment had been to fortify the Militia Clauses; now that these provisions were a dead letter, the Second Amendment was adrift.

But I concede, as I must, that neither Miller nor the lower court opinions building on it give any hint of these historical and structural concerns. ${ }^{329}$ This failure has significant costs. Not only has the opportunity to develop meaningful Second Amendment doctrine gone unrealized, but the Amendment's role in public debate has become distorted. Over the past two years, for example, Congress has debated a series of gun control measures advanced in the wake of the Columbine tragedy. During the same period, Congress also considered a resolution essentially reaffirming the War Powers Resolution, proposed in the context of major commitments of U.S. military personnel in the Middle East and in Bosnia. ${ }^{330}$ Senators and Representatives referred repeatedly to the Second Amendment in opposing the gun control

328. For that matter, Miller is also inconsistent with the strong version of the "collective rights" approach which turns the Second Amendment into a standing requirement. The Court never questions Miller's standing to raise a Second Amendment claim; the fact that his home state of Arkansas showed no interest in protecting Miller from imprisonment was quite properly immaterial to the Court. See infra Section II.A.

329. Some revisionist scholars attribute the tentativeness of the Court's opinion in Miller to the fact that the Court heard only from the government when the case was argued; Miller himself was not represented, having jumped bail and fled. See, e.g., Dowlut, supra note 3, at 73; Roy G. Weatherup, Standing Armies and Armed Citizens: An Historical Analysis of the Second Amendment, 2 HASTINGS CONST. L.Q. 961, 999 (1975).

330. See 145 CONG. REC. H59, 2414 (daily ed. April 28, 1999) (debate in House of Representatives on resolution to withdraw troops from overseas). 
provisions, ${ }^{331}$ the Amendment was not mentioned once in reference to the military. ${ }^{332}$

But while the courts' failure is costly, it should not seem surprising, as the method of constitutional interpretation I am advocating is sharply at variance with contemporary practice. Judges and lawyers, just as much as the Second Amendment revisionists, are caught in the trap of clause-bound, period-bound interpretation. Only by adopting a textually holistic and historically sensitive methodology can we uncover the reasons behind the disappearance of the Second Amendment and begin to think constructively about whether, and how, to revive it.

331. See 146 CONG. REC. E 1097 (daily ed. June 23, 2000) (statement of Rep. Weldon) 145 CONG. REC. E587, 1337 (daily ed. June 18, 1999) (statement of Rep. Barcia); 145 CONG. REC. S74, 5633 (daily ed. May 20, 1999) (statement of Sen. Smith); 145 CONG. REC. S59, 4319 (daily ed. April 28, 1999) (statement of Sen. McCain).

332. Based on a Lexis search of the Congressional Record for 1999 and 2000 (through August 1), using the search terms [("war powers" or Bosnia or Yugoslavia or troops) and "Second Amendment"]. 